\title{
Ultra low-field strenght intraoperative MRI for glioblastoma surgery
}

Citation for published version (APA):

Kubben, P. L. (2014). Ultra low-field strenght intraoperative MRI for glioblastoma surgery. [Doctoral Thesis, Maastricht University]. Maastricht University. https://doi.org/10.26481/dis.20140206pk

Document status and date:

Published: 01/01/2014

DOI:

10.26481/dis.20140206pk

Document Version:

Publisher's PDF, also known as Version of record

\section{Please check the document version of this publication:}

- A submitted manuscript is the version of the article upon submission and before peer-review. There can be important differences between the submitted version and the official published version of record.

People interested in the research are advised to contact the author for the final version of the publication, or visit the DOI to the publisher's website.

- The final author version and the galley proof are versions of the publication after peer review.

- The final published version features the final layout of the paper including the volume, issue and page numbers.

Link to publication

\footnotetext{
General rights rights.

- You may freely distribute the URL identifying the publication in the public portal. please follow below link for the End User Agreement:

www.umlib.nl/taverne-license

Take down policy

If you believe that this document breaches copyright please contact us at:

repository@maastrichtuniversity.nl

providing details and we will investigate your claim.
}

Copyright and moral rights for the publications made accessible in the public portal are retained by the authors and/or other copyright owners and it is a condition of accessing publications that users recognise and abide by the legal requirements associated with these

- Users may download and print one copy of any publication from the public portal for the purpose of private study or research.

- You may not further distribute the material or use it for any profit-making activity or commercial gain

If the publication is distributed under the terms of Article $25 \mathrm{fa}$ of the Dutch Copyright Act, indicated by the "Taverne" license above, 


\section{TABLE OF CONTENTS}

\section{CHAPTER 1}

General introduction

\section{CHAPTER 2}

Systematic review

CHAPTER 3

Volumetry

\section{CHAPTER 4}

Borderzone Sampling study

\section{CHAPTER 5}

Randomized trial

\section{CHAPTER 6}

General discussion

\section{CHAPTER 7}

Summary / Samenvatting

\section{CHAPTER 8}

Acknowledgments / Dankwoord

\section{CHAPTER 9}

Pieter Kubben (incl. curriculum vitae and bibliography) 


\section{INTRODUCTION}

\section{Magnetic resonance imaging}

In the history of brain tumor surgery, a few decades ago plain X-ray and angiography were the only imaging technologies available to the neurosurgeon. A brain tumor could be recognized by its "tumor blush", which refers to the vascular abnormalities associated with the tumor. About thirty years ago, computed tomography (CT) and magnetic resonance imaging (MRI) were introduced in patient care. Whereas CT is superior is displaying bony structures, MRI is superior in displaying soft tissue - a huge benefit for brain tumor imaging. Such images are available as so-called slices, which give a twodimensional orientation towards the brain.

In the operating room the neurosurgeon needs to "translate" the two-dimensional MRI pictures into a three-dimensional representation of the brain tumor and the surrounding structures. To assist the neurosurgeon in this process, a technique called "neuronavigation" has been introduced in the 1990's. To some extent this is comparable to a modern car navigation system: an MRI scan is made before surgery (the "roadmap"), and imported in the computer. In the operating room the neurosurgeon needs to instruct the computer how the patient is positioned on the operating table, and then a dedicated pointer (optical wand) can be moved over the head of the patient while the computer screen shows the underlying brain structures. This gives a more threedimensional orientation which helps the neurosurgeon to prepare for surgery and to optimize the surgical approach.

While this method is very useful for the planning of the surgical approach, it is less useful during the surgical procedure itself. As with a car navigation system, changes to the roadmap reduce the accuracy of the result. Such changes frequently happen during neurosurgical procedures: besides tumor resection also loss of cerebrospinal fluid and tissue edema contribute to anatomical changes that are not reflected on preoperative MRI. This phenomenon is referred to as "brain shift". To compensate for brain shift, several research groups have worked on new technology to update the "roadmap" to reflect changes that occur during surgery due to brain shift. This new technology is referred to as "intraoperative MRI" (iMRI). 


\section{iMRI}

Every magnet has a so-called field strength, expressed in Tesla (T). Regular diagnostic MRI as currently used in hospitals works with $1.5 \mathrm{~T}$ or $3 \mathrm{~T}$. When iMRI was introduced, iMRI devices worked with field strengths between $0.2 \mathrm{~T}$ and $0.5 \mathrm{~T}$. $[1,7,9]$ This is now referred to as "low-field strength" iMRI. The first commercially available iMRI system consisted of two vertically places magnets, and a neurosurgeon working in between of them. Because of its physical appearance, this system from General Electric was referred to as the "double doughnut".

Afterwards, development of this technology went into two directions: either the system was optimized for workplace integration, or the system was optimized for image quality.

This lead to the development of "(ultra) low-field strength" devices (between 0.12T and 0.5T) and "high-field strength" iMRI devices (1.5T or 3T). $[2,5,4,6,8,3]$ The goal of the (ultra) low-field strength devices was to support integration in the regular surgical workflow and cost-effectiveness, whereas the goal of high-field strength devices was to support optimal image quality and multimodality imaging (functional MRI, diffusion tensor imaging, magnetic resonance spectroscopy). The Maastricht University Medical Center works with a PoleStar N20 iMRI system (0.15T), shown in Figure 1.1.

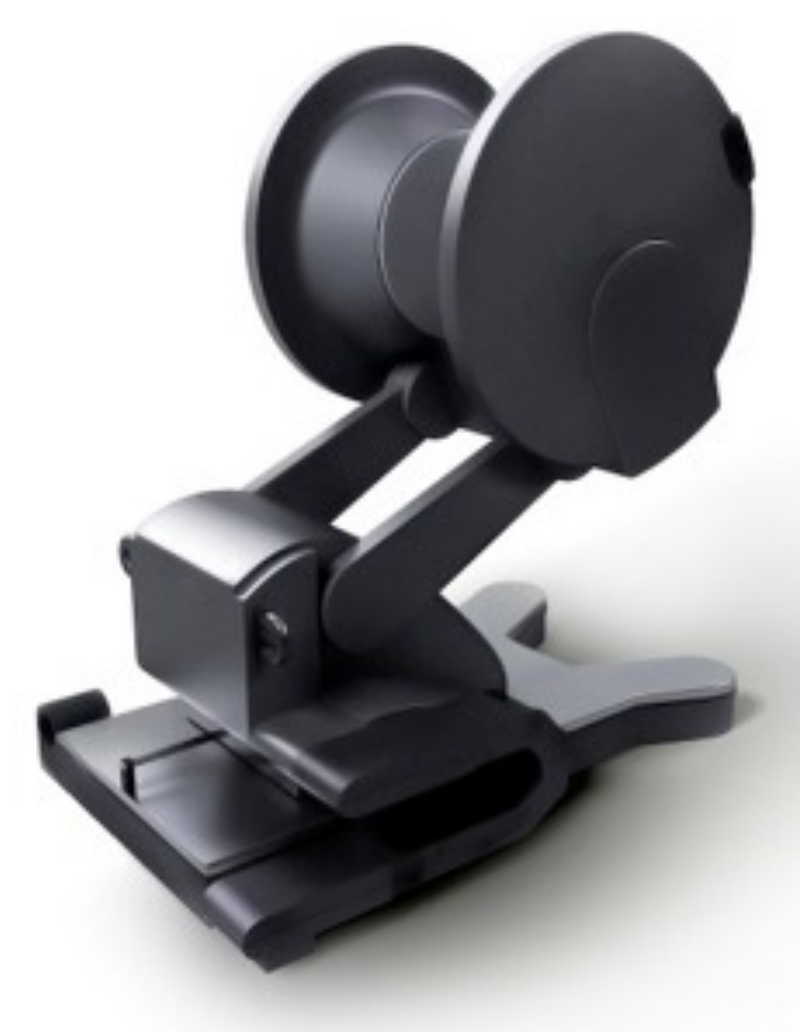

Figure 1.1: PoleStar N20 (0.15 Tesla) intraoperative MRI 
This ultra low-field strength iMRI system consists of two vertically placed permanent magnets that are lowered during surgery and raised during scanning (Figure 1.2).
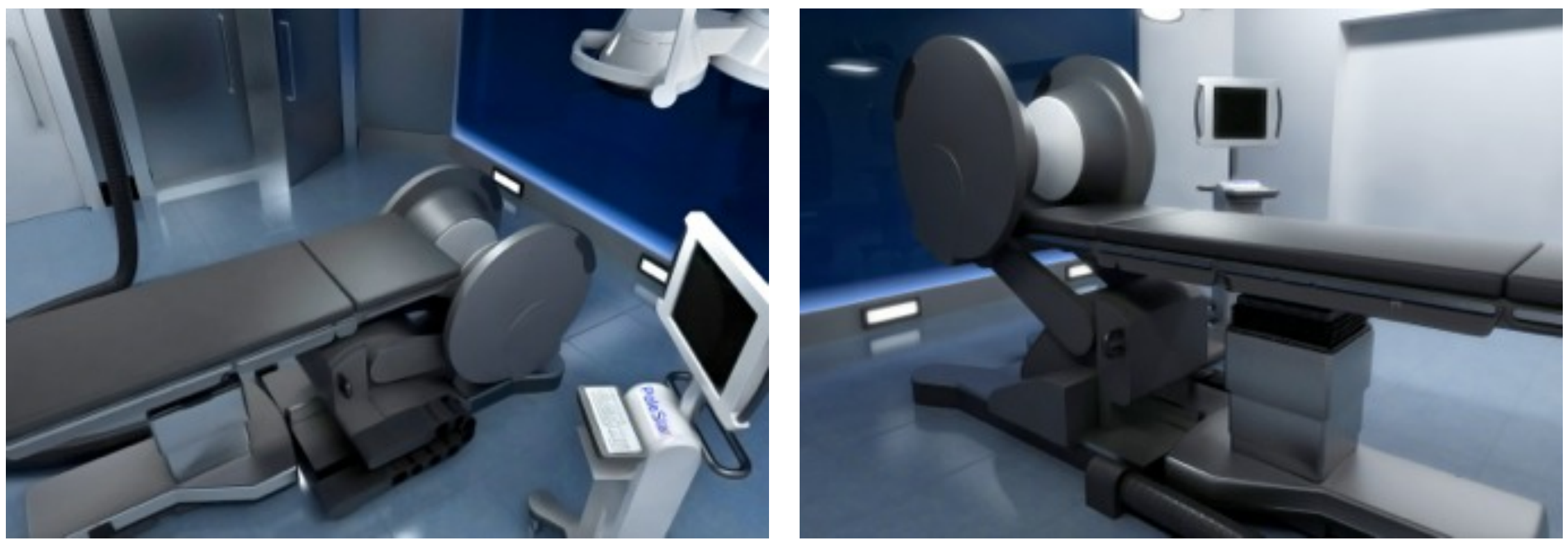

Figure 1.2: PoleStar during surgery (left) and during scanning (right)

The distance between both magnets is 27 centimeters and the field of view is $20 \times 16$ centimeters. Although this is sufficient for patient positioning it does require extra considerations on how to place the headclamp. The MR signal is measured by a coil which is placed over the head of the patient (Figure 1.3).

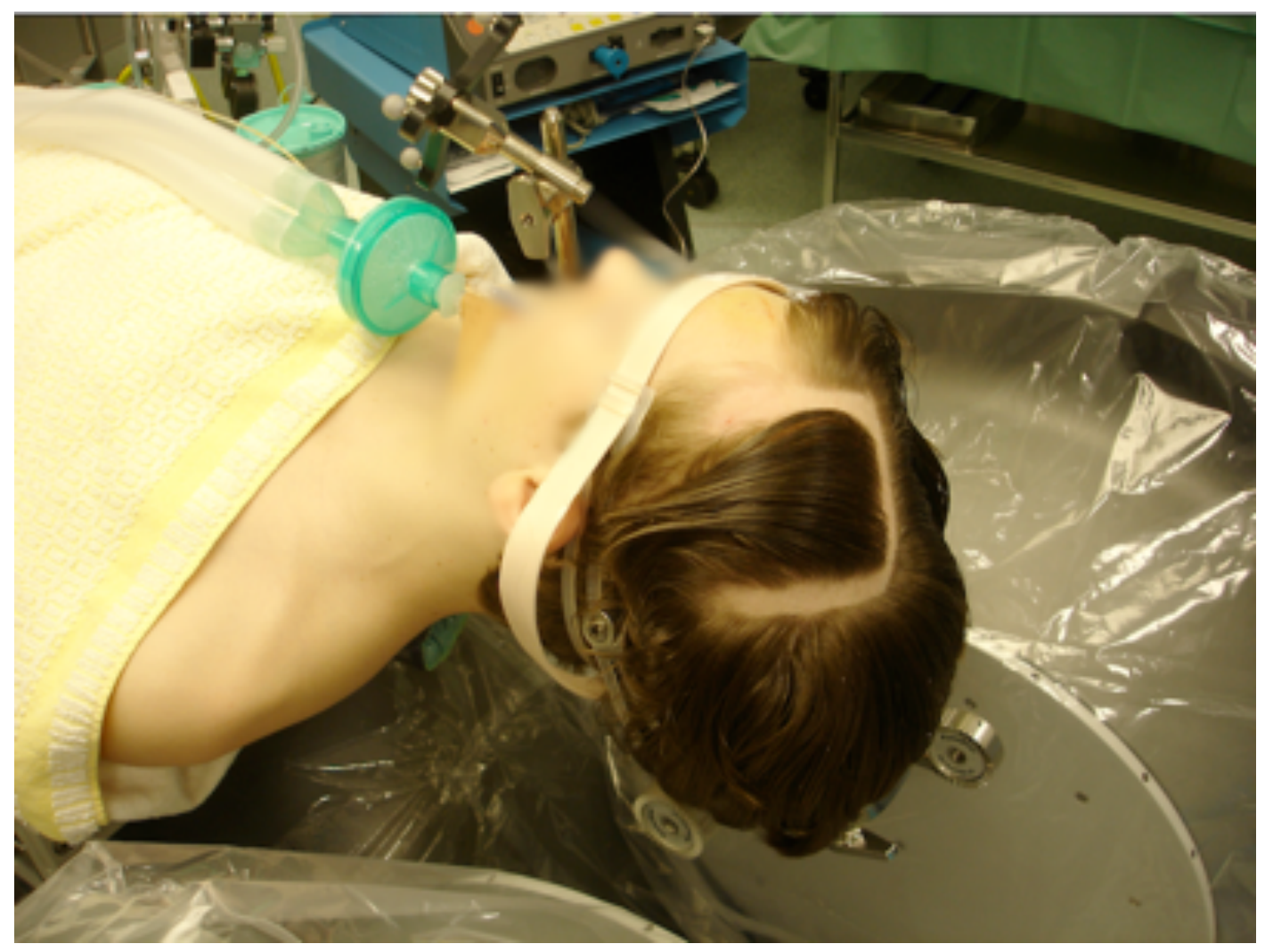

Figure 1.3: The (signal receiving) coil is placed over the head of the patient. 
In order to measure the iMRI signal, radiofrequency signals coming from other sources than the magnet must be absent as much as possible. This so-called shielding is done by a Faraday cage. Most (i)MRI suites have shielded room, which means that the Faraday cage is integrated in the walls of the (i)MRI suite. With the ultra low-field strength iMRI device it is also possible to use "local shielding" by means of a tent that encloses the patient during scanning (the StarShield $($ )). This is shown in Figure 1.4 .

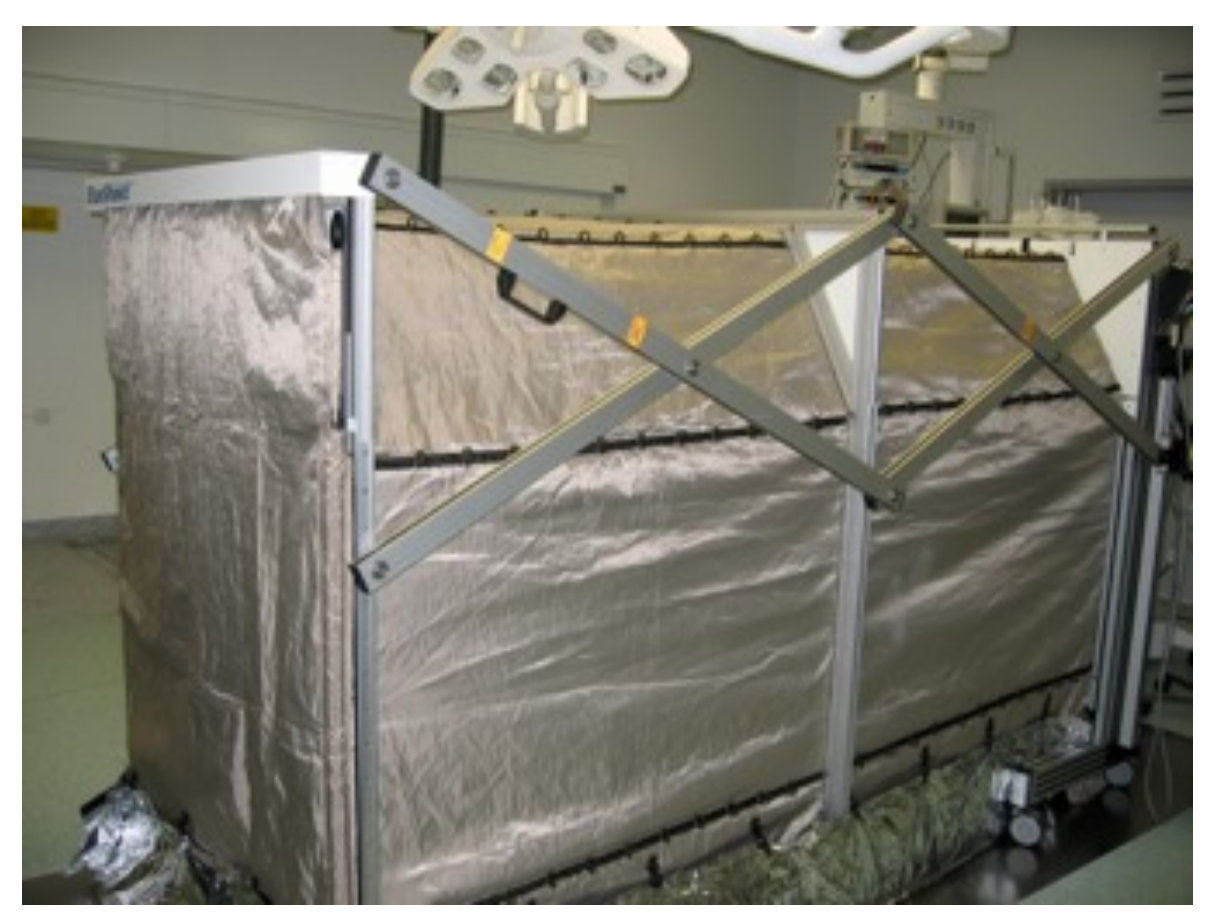

Figure 1.4: The StarShield@ during scanning

When the system is not in use, it can be stored in a dedicated storage cabinet (Figure 1.5). In that case, the operating room can be used as a regular operating room without any magnetic interference.

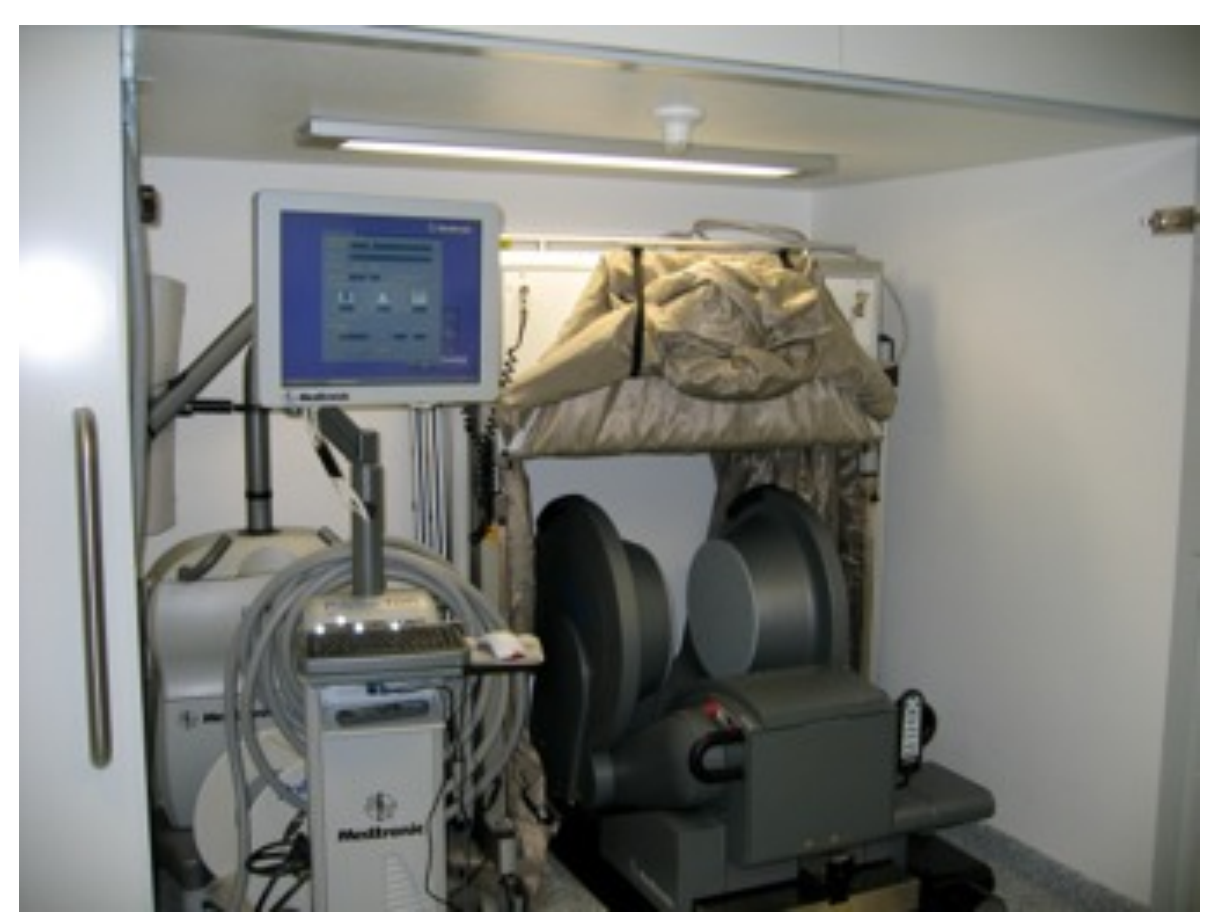

Figure 1.5: The iMRI system in the storage cabinet 


\section{Brain tumors}

Several sorts of brain tumors may benefit from iMRI-guided treatment, of which gliomas and pituitary adenomas are the most common. Regardless of which technology is used, the overall aim is to optimize the extent of tumor resection (EOTR) without causing (additional) neurologic deficit. This is particularly true for gliomas, based on a growing body of scientific literature that increased EOTR is associated with prolonged survival. Many papers were published in scientific journals claiming the added value of iMRI with respect to EOTR, but a systematic review of the literature had not yet been performed.

\section{Aim of this thesis}

For this thesis the focus is on glioblastoma, the most aggressive subtype of the glioma tumor family. The median survival for a glioblastoma is 14.6 months after radiotherapy and chemotherapy with temozolomide. The central question of this thesis is whether iMRI-guided surgery is more beneficial for patients with a glioblastoma than the standard therapy (conventional neuronavigation-guided surgery).

In chapter 2, a systematic review is performed to evaluate the existing literature on the topic. This systematic review was published in 2011 in Lancet Oncology, and demonstrates several sorts of bias in the literature that was published to date. In the same issue, the first randomized controlled trial on this topic was published by Senft et al. The results and conclusions of this randomized trial are discussed in chapter 5 and chapter 6.

In chapter 3, the intraobserver and interobserver agreement of tumor volumetry is analyzed. Tumor volumetry is a common endpoint in recent neurosurgical studies that evaluate the effect of EOTR on patient outcome, but it has never been validated.

In chapter 4, the correlation between contrast enhancement on iMRI and presence of tumor tissue on histology is evaluated. The rationale behind removal of contrast enhancing tissue as visible on (i)MRI is that this correlates to tumor presence. This has never systematically been analyzed for iMRI, and iatrogenic damage to the blood-brain barrier might cause a different enhancement pattern compared to preoperative (diagnostic) MRI. 
In chapter 5, the results of our international multi-center randomized controlled trial are presented. The primary endpoint is EOTR based on preoperative and postoperative imaging. Secondary endpoints focus on clinical performance, health-related quality of life and survival. The results, conclusions, and differences compared to the Senft study are discussed.

In chapter 6 a discussion is presented that combines all topics from the previous chapters, that evaluates the current level of scientific evidence for the central question in the thesis, and that offers suggestions for future research. 


\section{DISCLAIMER}

Part of the research work presented in this PhD thesis (chapter 4 and chapter 5) has been supported by Medtronic Navigation by means of an unrestricted grant. Medtronic Navigation was not involved in writing the related study protocols, had no access to the data, was not involved in writing the manuscripts and had no veto right for submission. 


\section{REFERENCES}

1. Black PM, Moriarty T, Alexander E, Stieg P, Woodard EJ, Gleason PL, et al. Development and implementation of intraoperative magnetic resonance imaging and its neurosurgical applications. Neurosurgery $1997 ;$ 41:831-42- discussion 842-5.

2. Hadani M. Novel, Compact, Intraoperative Magnetic Resonance Imaging-guided System for Conventional Neurosurgical Operating Rooms. Neurosurgery 2001;:11.

3. Hall WA, Galicich W, Bergman T, Truwit CL. 3-Tesla intraoperative MR imaging for neurosurgery. J Neurooncol 2006; 77:297-303.

4. Levivier M, Wikler D, De Witte O, De Steene Van A, Bal Riaux D, Brotchi J. PoleStar N-10 Low-field Compact Intraoperative Magnetic Resonance Imaging System with Mobile Radiofrequency Shielding. Neurosurgery 2003;:1001-1007.

5. Schulder M. Cranial surgery navigation aided by a compact intraoperative magnetic resonance imager. J Neurosurg 2001;:10.

6. Schulder M. Cranial surgery with an expanded compact intraoperative magnetic resonance imager. J Neurosurg 2006;:7.

7. Steinmeier R, Fahlbusch R, Ganslandt O, Nimsky C, Buchfelder M, Kaus M, et al. Intraoperative magnetic resonance imaging with the magnetom open scanner: concepts, neurosurgical indications, and procedures: a preliminary report. Neurosurgery 1998; 43:739-47-discussion 747-8.

8. Sutherland GR. A mobile high-field magnetic resonance system for neurosurgery. J Neurosurg $1999 ;: 10$.

9. Wirtz CR, Bonsanto MM, Knauth M, Tronnier VM, Albert FK, Staubert A, et al. Intraoperative magnetic resonance imaging to update interactive navigation in neurosurgery: method and preliminary experience. Comput. Aided Surg. 1997; 2:172-179. 
A $A x,=2-3.0$ Gd-DI $7 \mathrm{~A}$ 098

A $\quad 1 \times, 5 p-1.5$

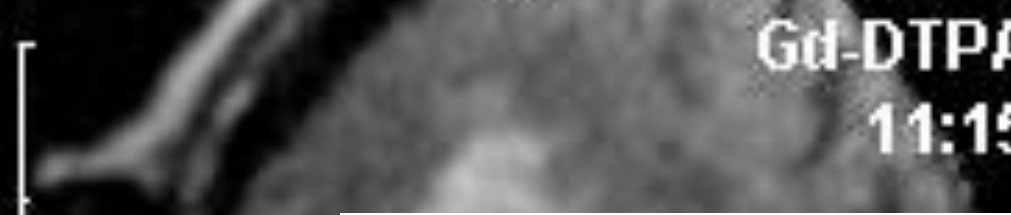

\section{[}

2

SYSTEMATIC

REVIEW

$10 \mathrm{~cm}$

"Intraoperative MRI-guided resection of glioblastoma multiforme: a systematic review."

Kubben PL, Meulen Ter KJ, Schijns OE, Ter LaakPoort MP, Van Overbeeke JJ, Van Santbrink H. The Lancet Oncology. 2011 Aug 23;12(11):106270. 


\section{INTRODUCTION}

Intraoperative MRI (iMRI)-guided intracranial surgery has been introduced more than a decade ago.[4] Starting at 0.5 Tesla (T) with the so-called "double doughnut" system, iMRI systems evolved into two directions: (ultra) low-field strength iMRI and high-field strength iMRI. Generally low-field strength refers to iMRI systems of $0.5 \mathrm{~T}$ or less, and ultra low-field specifically refers to iMRI systems of less than $0.2 \mathrm{~T}$. High-field strength systems started at $1.5 \mathrm{~T}$ but also $3 \mathrm{~T}$ systems are in use. The balance between low-field and high-field strength systems mainly depends on a choice between required image quality, available imaging modalities, integration in the existing workflow, and cost.

The main rationale for use of $\mathrm{iMRI}$ is intraoperative resection control. During surgery, the brain parenchyma gets distorted due to loss of cerebrospinal fluid, edema and tumor resection. This phenomenon is referred to as "brain shift". As a consequence, using preoperative MRI for conventional neuronavigation (cNN) becomes less reliable during surgery. Intraoperative imaging can update the source images that are used for neuronavigation. For visualization of brain parenchyma, images are preferably acquired using MRI. Therefore iMRI is useful: (1) to update neuronavigation information, and (2) to visualize remaining contrast enhancing tissue, suspect to be tumor. Frequently reported indications for iMRI-guided surgery are intra-axial tumors[3,8,22,40,45,44,48,51,52,54,61] and pituitary adenomas.[45,48,54,6,9,46,49,56,12]

Since the introduction of iMRI, many papers have reported about the (added) value of iMRI-guided surgery.[3,8,22,40,42,44,48,51,52,5,56,13,16,14,15,17,24,28,39,38] However, to the best of our knowledge no systematic review on this topic has been published yet. As iMRI-guided surgery requires expensive equipment and prolongs the time of surgery, justification for widespread use should preferably be based on evidence. We conducted a systematic review of the literature in line with the PRISMA Statement.[30] As various types of pathology require different surgical strategies, we decided to focus on high grade gliomas in general, and glioblastomas in particular. The objective is to address the added value of iMRI-guided resection of glioblastoma compared to cNN-guided resection with respect to extent of tumor resection (EOTR), quality of life, and survival. 


\section{METHODS}

\section{Research protocol}

Our review protocol consisted of the detailed research question, the search strategy, the screening criteria for titles and abstracts, and the screening criteria for full-text articles. The detailed research question was structured using the so-called PICOS approach (Patient, Intervention, Comparator, Outcome, Study design). Our PICOS research question was formulated as follows: is iMRI-guided tumor resection in adults with glioblastoma more effective than cNN-guided resection with respect to EOTR, quality of life, and survival, as published in randomized controlled trials and cohort studies?

Search databases were MEDLINE (using PubMed), EMBASE (using OVID), the Cochrane Library and ClinicalTrials.gov. Search queries were optimized for each specific database.

After deleting duplicate records, titles and abstracts were screened and included if they represented randomized or cohort studies on patients with glioblastoma or high grade glioma who received neurosurgical intervention using iMRI. Studies that specifically reported on a pediatric population or focused on radiosurgery, radiotherapy or chemotherapy were excluded at this point. Of the remaining records full-text articles were assessed according to the same criteria, with one additional inclusion criterion (quantitative information on added value of iMRI) and with one additional exclusion criterion (overlapping data). A spreadsheet contained all data collection items for the full-text versions of included articles (reflected in Tables 2.2-2.4). The research protocol has been set up by the first and last author (PK, HvS) and searches were performed independently by the first two authors (PK, KtM). The last author served as an independent third reviewer in case differences in opinion between the two reviewers existed.

\section{Eligibility criteria and search strategy}

The PICOS research question served as the foundation for study selection, without additional restrictions in publication date, length of follow-up, language or publication status. As iMRI is a fairly new technique, the topic itself will limit the publication dates. We used the previously mentioned databases for searching. We decided to use MEDLINE / PubMed as our primary data source, and included "glioma" as a medical subject heading (MeSH) to search with maximum sensitivity. Other databases were used to find additional literature on glioblastomas or high grade gliomas (HGGs). Of these two only "glioblastomas" turned out to be a valid thesaurus term (EMBASE) or useful keyword (Cochrane Library). Full search strategies are detailed for each database in the next paragraph. 
The MEDLINE query with MeSH terms was: ("Magnetic Resonance Imaging, Interventional"[Mesh] OR "Surgery, Computer-Assisted"[Mesh] OR "Neuronavigation"[Mesh] OR "Therapy, ComputerAssisted"[Mesh]) AND ("Glioma"[Mesh] OR "Glioblastoma"[Mesh]). The OVID query with thesaurus terms was: ("interventional magnetic resonance imaging" OR "computer assisted surgery" OR "neuronavigation") AND ("glioblastoma"). The Cochrane Library query with keywords was: ((Magnetic Resonance Imaging, Interventional):kw or (neuronavigation):kw or (Surgery, Computer-Assisted):kw) and (glioblastoma):kw. The ClinicalTrials.gov query consisted of free text: (intraoperative mri OR interventional mri OR neuronavigation OR computer-assisted surgery) AND glioblastoma.

\section{Study selection and data collection}

After record screening full-text assessment of articles was performed for study selection. An additional inclusion criterion for full-text assessment was quantitative information on the added value of iMRI specific for glioblastoma or HGG. Added value was described as one or more of the PICOS outcome parameters. An additional exclusion criterion for full-text assessment was overlapping data from the same cohort in different studies. In this case, the study with the most specific information on glioblastoma or HGG was selected.

Data collection was done in a prospectively designed questionnaire with Microsoft Excel (Microsoft Corporation, Redmond, WA). The data collection items were separated in three categories: study design parameters (Table 2.2), iMRI parameters (Table 2.3) and study population and resection parameters (Table 2.4). No meta-analysis was planned as we did not expect that a valid quantitative data synthesis could be performed. Especially differences in the magnet's field strength were thought to influence image quality and thus the results. 
RESULTS

\section{Study selection}

Figure 2.1 represents the various stages in searching the literature and selecting studies for eligibility.

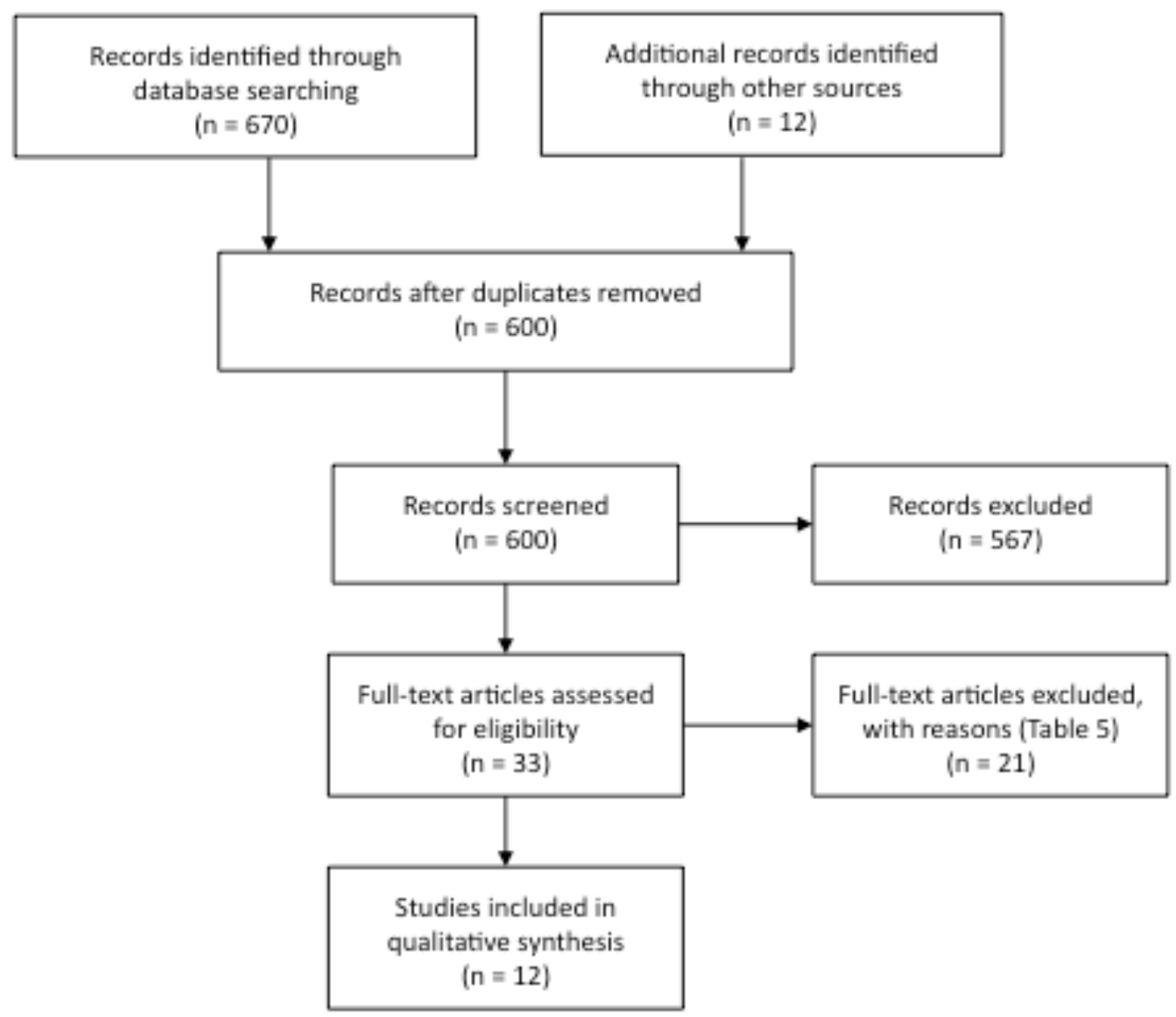

Figure 2.1: Flow diagram for literature assessment

Database searching identified 670 records, and another 12 records were identified through other sources. After removing duplicates, 600 records were available for screening. Of these, 567 were excluded because they did not meet the selection criteria. After full-text assessment of the remaining 33 articles, another 21 were excluded from the qualitative synthesis. The reasons for excluding articles after full-text assessment are displayed in Table 2.1. Three of these were only excluded after the independent assessment by a third reviewer, because the first two reviewers disagreed. These are marked with an asterisk in Table 2.1. The remaining 12 articles were used for qualitative synthesis. 


\section{Table 2.1: Reasons for excluding articles after full-text assessment}

\section{Reference}

Bergsneider, 2005 [2]

Black, 1999 [3]

Fuji, 2009 [10]

Ganslandt, 2002 [11]

Jankovski, 2008 [20]

Lewin, 2007 [29]

Maesawa, 2009 [32]

McPherson, 2003 [34]

Nimsky, 2002 [45]

Nimsky, 2003 [37]

Nimsky, 2004 [40] *

Nimsky, 2004 [44]

Nimsky, 2009 [47] *

Ram, 2003 [50]

Schulder, 2001 [53]

Schulder, 2006 [54]

Schulder, 2009 [55]

Senft, 2008 [59] *

Senft, 2010 [58]

Trantakis, 2003 [63]

Yrjänä, 2007 [66]

\section{Reason for exclusion}

No specific results for HGG or GBM

No specific data for HGG or GBM

Article in Japanese and no translator available

Focused on neuronavigation, and does not offer specific data on HGG or GBM

No specific results for $\mathrm{HGG}$ or GBM

No specific data for HGG or GBM

No specific data for HGG or GBM

No specific data for HGG or GBM

Overlapping data with included study 38

Overlapping data with included study 34

Overlapping data with included study 34

Overlapping data with included study 34

Focused on accuracy of updating neuronavigation

No specific data for HGG or GBM

No specific data for HGG or GBM

No specific data for HGG or GBM

No specific data for HGG or GBM

Overlapping data with included study 41

Overlapping data with included study 41

Overlapping data with included study 10

No specific data for HGG or GBM

\section{Abbreviations: GBM = Glioblastoma Multiforme, $H G G=$ High Grade Glioma .}

Articles marked with asterisk $\left({ }^{*}\right)$ were only excluded after full-text assessment by an independent third reviewer.

\section{Study characteristics}

Twelve studies met our selection criteria: 2 prospective and 10 retrospective cohort studies. If the prospective or retrospective design was not specified in the full-text article, then it was assessed independently by both reviewers, who agreed in all cases. We did not find any randomized controlled trials (RCT) that met the selection criteria. Most studies offered descriptive statistics of a heterogeneous population, consisting of mixed pathology. Publication years were between 1999 and 2010 . Most studies offered inclusion criteria for patient selection, and only two offered exclusion criteria. 
Mostly the description of the study population was in general terms, like "all gliomas" operated in a certain time frame. Most studies offered data on EOTR, although this was measured in different ways. All studies offered information on the iMRI system that was used, including field strength of the magnet and MR sequences used during surgery. Information on used contrast agent was more limited, and mentioned in 8 out of 12 studies.[7,27,41,58] Only 3 out of 12 studies explicitly mentioned the cumulative additional time spent in the operating room when iMRI was used.[22,7,19] This cannot indirectly be calculated from the scanning time itself, as a longer preparation time before incision and longer preparation times before and immediately after scanning do need to be taken into account.

10 out of 12 studies offered a description on how gross total resection (GTR) was defined. 7 out of 12 studies described how the use of iMRI influenced EOTR and helped in achieving GTR. Only 2 out of 12 studies also explicitly stated in how many patients GTR was intended.

Outcome parameters were often mentioned without stratification for the various pathological diagnoses. Survival data were available in 4 out of 12 studies, comparing GTR to subtotal resection or iMRIguided surgery to cNN-guided surgery (non-randomized or matched control group).[52,65,58,19]

The detailed study design parameters for the selected studies are displayed in table 2.2. Table 2.3 shows their iMRI parameters, and table 2.4 their study population and resection parameters.

\section{Results of individual studies}

The focus of our search question was on HGG in general, and glioblastoma in particular. Therefore we extracted these data from the selected studies, even if the original studies analyzed a broader spectrum of pathology. In the next paragraphs we will highlight the most important messages of each selected study in alphabetical order, and information that was found to be missing and maybe influencing the conclusions. Details are available in Tables 2.2-2.4.

Knauth et al (1999)[22] retrospectively analyzed $41 \mathrm{HGG}$ cases (in 38 patients) on a 0.2 Tesla (T) scanner and double-dose $(0.2 \mathrm{mmol} / \mathrm{kg})$ of contrast agent. GTR was intended in all cases. On the first iMRI scan GTR was achieved in 37\% of cases. The authors did not describe the results of the last iMRI scan, but mention that GTR was achieved in $76 \%$ of cases according to early postoperative MRI. Clinical performance was not specified.

Wirtz et al (2000)[65] retrospectively analyzed 68 HGG cases (of which 62 had glioblastoma) on a $0.2 \mathrm{~T}$ scanner and a double-dose of contrast agent. Scans were made directly and 5, 10 and 20 
minutes after contrast administration. GTR was defined as removal of contrast enhancement as visible on T1-weighted MRI. On the first iMRI scan GTR was achieved in 27\% of HGG cases and in 67\% of cases resection was continued based on the iMRI scan. The authors did not describe the results of the last iMRI scan, and do not mention the number of HGG cases where GTR was intended. Median survival was 13.3 months for the GTR cases compared to 9.2 months for the STR cases ( $p=0.0035$ ). Clinical performance was not specified for the HGG or glioblastoma subpopulation.

Bohinski et al (2001)[5] prospectively analyzed their results with $30 \mathrm{HGG}$ patients on a 0.3T iMRI scanner and single-dose $(0.1 \mathrm{mmol} / \mathrm{kg})$ of contrast agent. In $60 \%$ of HGG patients iMRI lead to additional resection. The authors did not describe the number of HGG patients in which gross total resection (GTR) was intended, nor the results of the last iMRI scan. Clinical performance was not specified for the HGG subpopulation.

Nimsky et al $(2003,2006)[36,41]$ analyzed 32 glioblastoma cases on a 0.2T scanner with a singledose of contrast agent administered just prior to scanning, and 57 glioblastoma cases on a 1.5T scanner with a single-dose of contrast agent as well. On the $0.2 T$ scanner GTR was achieved in 6/32 cases on the first iMRI scan, and in 7/32 cases on the last iMRI scan. The number of intended GTRs was not specified for this group. On the 1.5T scanner GTR was achieved in 16/57 cases on the first iMRI scan and in 23/57 cases on the last iMRI scan. Although the number of intended GTRs was not specified for this group either, from the text could be derived that GTR was not intended in at least $25 / 57$ cases. It should be noted that the authors performed a smaller study on volumetric assessment of glioma removal (excluded for overlapping data) by applying manual segmentation on a dedicated workstation, using co-registration of all imaging data sets. The authors reported a mean additional resection of $12 \%$ in intended subtotal resection cases, and a mean additional resection of $20 \%$ in intended GTR cases. Clinical performance was not specified for the glioblastoma subpopulation.

Hirschberg et al (2005)[19] retrospectively analyzed 32 glioblastoma cases (of which 27 were eligible for further analysis) on a 0.5T iMRI scanner. Although the number of cases in which GTR is intended is not explicitly specified, this seems to be 19/27 cases (derived from text). On the first iMRI GTR is achieved in 5/27 cases. The authors did not provide data for the last iMRI scan. Contrast agent was not specified in the text, nor its dose. Median survival in the iMRI group was 14.5 months compared to 12.1 months for a matched control group. This difference was not statistically significant $(p=0,14)$. Clinical performance improved in $16 \%$ of cases, remained unchanged in $55 \%$ and deteriorated in $29 \%$. 
Schneider et al (2005)[52] retrospectively analyzed 31 primary glioblastoma cases on a 0.5T scanner with a single-dose of contrast agent immediate before scanning and 4 hours afterwards if a new iMRI scan was required. EOTR was assessed volumetrically and GTR was defined as $>95 \%$ removal of the contrast-enhancing mass (including necrosis) on T1-weighted MRI. GTR was achieved in 2/31 patients on the first iMRI scan and in 11/31 patients on the last iMRI scan. The number of intended GTRs was not specified. The authors describe a median survival of 537 days for GTR compared to 237 days for subtotal resection (STR; $p=0.004$ ). There were no further volumetric data of the EOTR for the STR group, so all EOTR $<95 \%$ were represented. Clinical performance deteriorated in $13 \%$ of patients.

Busse et al (2006)[7] retrospectively analyzed 24 glioblastoma cases on a $0.5 \mathrm{~T}$ iMRI scanner, leading to a "total" resection on the last iMRI scan in 4/24 patients according to consensus between the neuroradiologist and the neurosurgeon. The authors did not provide any information on the first iMRI scan and the contrast dose. Clinical performance was not specified for the glioblastoma subpopulation. The authors mainly evaluated their results to compare real-time reformatted iMRI scans with successive iMRI scans. We did not use that stratification in this review.

Muragaki (2006)[35] et al retrospectively analyzed 30 glioblastoma cases on a 0.3T scanner. They used a double-dose of contrast agent for their most recent cases, and a single-dose for the earlier ones. They used manual segmentation to measure the EOTR volumetrically, defined as removal of contrast-enhancing tissue as visible on T1-weighted MRI. At the last iMRI scan in 90\% EOTR was achieved. They did neither provide details on the number of intended GTRs, nor on the results on the first iMRI scan. Also the different doses of contrast agent may influence the results for EOTR. Clinical performance was not specified for the glioblastoma subpopulation.

Hatiboglu et al (2009)[18] prospectively analyzed 27 glioblastoma cases on a 1.5T scanner with a single-dose of contrast agent. EOTR was assessed with volumetry, and GTR was defined as $>95 \%$ EOTR on contrast-enhanced T1-weighted MRI. Manual segmentation was performed by 2 neurosurgeons, and according to the authors their technique was equivalent when they were tested for variability in their determinations. No specification was provided whether this only concerned segmentation on preoperative images, or on postoperative images as well. The first iMRI scan showed GTR in 12/27 patients, and the last iMRI scan in 24/27 patients. The authors selected patients with tumors near eloquent areas, but did not explicitly describe in what number of patients GTR was intended. Clinical performance was not specified for the glioblastoma subpopulation. 
Lenaburg et al (2009)[27] retrospectively analyzed 35 glioblastoma cases (in 29 patients) on a 0.2T scanner. The first iMRI scan lead to further resection in $72 \%$ of cases, and the last iMRI scan showed a resection $>95 \%$ in 27/35 cases. However, EOTR was calculated using a mathematical "spherebased" model. In our opinion, this cannot be used for postoperative imaging, which makes comparison with preoperative tumor volume unreliable. The authors did not provide information on contrast agent, and did not mention the number of cases in which GTR was intended. Clinical performance deteriorated in $1 / 35$ patients.

Senft et al (2010)[57] retrospectively analyzed 41 primary glioblastoma cases on a $0.15 T$ scanner. GTR was intended in all cases. 10 glioblastoma cases were operated with iMRI and 31 were operated with cNN. GTR was defined as absence of contrast-enhancement on T1-weighted MRI. Postoperative MRI within 72 hours after surgery showed GTR in 10/10 iMRI cases and in 19/31 cNN cases. When related to EOTR, median survival was 74 weeks for the GTR group compared to 46 weeks for the STR group $(p<0.001)$. When related to the treatment group, median survival was 88 weeks for the iMRI group compared to 68 weeks for the cNN group. However, the treatment group survival data were not statistically significant $(p=0.07)$. Treatment group allocation was not randomized, therefore selection bias could be present in this study. Further no information was available on the contrast agent that was used. Clinical performance was not specified. 
Table 2.2: Study design parameters of included studies

\begin{tabular}{|c|c|c|c|c|}
\hline Reference & Type & Inclusion criteria & Exclusion criteria & Time frame \\
\hline Knauth, 1999 [22] & $\mathrm{R}$ & $H G G$ & NS & NS \\
\hline Wirtz, 2000 [65] & $\mathrm{R}$ & supratentorial glioma; IC & NS & $\begin{array}{l}\text { NS ("from Dec } \\
\text { 1995" until } \\
\text { maximally Aug } \\
\text { 1999) }\end{array}$ \\
\hline Bohinski, 2001 [5] & $\mathrm{P}$ & $\begin{array}{l}\text { primary and recurrent } \\
\text { supratentorial glioma WHO } \\
\text { grade } 2,3,4 ; \text { age } \geq 18 y \text {; IC }\end{array}$ & NS & $\begin{array}{l}\text { May } 1998-\text { Oct } \\
1999\end{array}$ \\
\hline Nimsky, 2003 [36] & $\mathrm{R}$ & supratentorial glioma & NS & $\begin{array}{l}\text { Mar } 1996-\text { Jul } \\
2001\end{array}$ \\
\hline Hirschberg, 2005 [19] & $R$ & GBM with follow-up $\geq 2 \mathrm{~m}$ & NS & $\begin{array}{l}\text { Jan } 1999-\text { Jun } \\
2002\end{array}$ \\
\hline Schneider, 2005 [52] & $\mathrm{R}$ & $\begin{array}{l}\text { supratentorial GBM confirmed } \\
\text { by } 2 \text { neuropathologists; no } \\
\text { recurrent tumor; age } \geq 18 \mathrm{y} \text {; } \\
\text { preoperative KPS } \geq 70 \text {; ASA } \\
\text { class } 1 \text { or } 2 \text {; IC }\end{array}$ & NS & $\begin{array}{l}\text { Sep } 1997-\text { Jan } \\
2002\end{array}$ \\
\hline Busse, 2006 [7] & $\mathrm{R}$ & $\begin{array}{l}95 \text { cases of } 3 \text { neurosurgeons } \\
\text { who all did } \geq 10 \mathrm{iMRI} \\
\text { surgeries; IC }\end{array}$ & NS & $\begin{array}{l}\text { NS }(3,5 y \\
\text { timeframe) }\end{array}$ \\
\hline Muragaki, 2006 [35] & $\mathrm{R}$ & $\begin{array}{l}\text { intracranial glioma surgery } \\
\text { with iMRI; IC }\end{array}$ & NS & Jul 2000 - Jul 2004 \\
\hline Nimsky, 2006 [41] & $\mathrm{R}$ & glioma; IC & NS & $\begin{array}{l}\text { Apr } 2002-\text { Aug } \\
2005\end{array}$ \\
\hline Hatiboglu, 2009 [18] & $P$ & $\begin{array}{l}\text { large, infiltrative or within/near } \\
\text { eloquent areas located } \\
\text { gliomas; IC }\end{array}$ & $\begin{array}{l}\text { No postoperative } \\
\text { MRI }\end{array}$ & $\begin{array}{l}\text { Sep } 2006 \text { - Aug } \\
2007\end{array}$ \\
\hline Lenaburg, 2009 [27] & $\mathrm{R}$ & GBM; IC & NS & Jul 2002 - Jul 2006 \\
\hline Senft, 2010 [57] & $\mathrm{R}$ & $\begin{array}{l}\text { primary GBM, histologically } \\
\text { confirmed; intended GTR; KPS } \\
\geq 70 \text {; IC }\end{array}$ & $\begin{array}{l}\text { recurrent tumor, } \\
\text { intended STR, } \\
\text { biopsies }\end{array}$ & $\begin{array}{l}\text { Jul } 2004-\text { Dec } \\
2005\end{array}$ \\
\hline
\end{tabular}


Table 2.2 (continued): Study design parameters of included studies
Reference
Primary endpoint
Primary endpoint measurement

Knauth, 1999 [22]

CE on $\mathrm{MRR}$ and EPMRI

NS

Wirtz, 2000 [65]

EOTR

Bohinski, 2001 [5]

EOTR

scan interpretation

interpretation by neuroradiologist

Nimsky, 2003 [36]

NS ("our experience")

N/A

Hirschberg, 2005 [19]

NS ("impact on procedure,

(data analysis)

outcome and median survival")

Schneider, 2005 [52] EOTR

volumetry based on manual segmentation

Busse, 2006 [7] $\quad$ EOTR consensus neurosurgeon and neuroradiologist

Muragaki, 2006 [35] focus on functional outcome neurologic status and comorbidity

Nimsky, 2006 [41]

NS ("the effects of iMRI and NS functional neuronavigation in glioma surgery")

Hatiboglu, 2009 [18] EOTR

volumetric analysis on Vitrea workstation by 2 neurosurgeons

volumetry (sphere model)

GTR defined as no residual CE on EPMRI, evaluated by neuroradiologist blinded for treatment modality

Lenaburg, 2009 [27] EOTR

Senft, 2010 [57]

EOTR 
Table 2.3: Intraoperative MRI parameters of included studies

Reference

Contrast administration

$\begin{array}{lllll} & & \text { Agent } & \text { Dose } & \text { Timing } \\ \text { Knauth, 1999 [22] } & 0,2 & \text { Gd-DTPA } & 0,2 \mathrm{mmol} / \mathrm{kg} & \text { NS }\end{array}$

Wirtz, $2000[65] \quad 0,2 \quad$ Gd-DTPA $\quad 0,2 \mathrm{mmol} / \mathrm{kg}$

scans 0, 5, 10 and $20 \mathrm{~m}$ after

contrast administration

Bohinski, $2001[5] \quad 0,3$ gadodiamide $0,1 \mathrm{mmol} / \mathrm{kg} \quad$ NS

Nimsky, 2003 [36] 0,2 Gd-DTPA 0,2 $\mathrm{ml} / \mathrm{kg} \quad$ just prior to scanning

Hirschberg, $2005 \quad 0,5$ gadolinium NS NS

[19]

(NS)

Schneider, $2005 \quad 0,5$ Gd-dimeg $\quad 0,1 \mathrm{mmol} / \mathrm{kg} \quad$ before scanning and $4 \mathrm{~h}$ afterwards

[52]

(if new scan necessary)

Busse, $2006[7] \quad 0,5 \quad$ NS $\quad$ NS $\quad$ NS

Muragaki, $2006 \quad 0,3 \quad$ Gd-DTPA $\quad 0,4 \mathrm{ml} / \mathrm{kg} \quad$ NS

[35]

$(0,2 \mathrm{ml} / \mathrm{kg}$ previously $)$

Nimsky, 2006 [41] 1,5 Gd-DTPA* 0,2ml/kg* before scanning*

Hatiboglu, $2009 \quad$ 1,5 Gd-dimeg $\quad 0,2 \mathrm{ml} / \mathrm{kg} \quad$ NS

[18]

Lenaburg, $2009 \quad 0,2 \quad$ NS

NS

NS

[27]

Senft, 2010 [57] 0,15 NS

NS

NS 
Table 2.3 (continued): Intraoperative MRI parameters of included studies (continued)

Reference Scanning time iMRI sequences used Extra OR time

Knauth, 1999 [22] NS

$\mathrm{T} 1$

1h for scanning and setup

Wirtz, 2000 [65]

NS

T1, T2, FLAIR

NS

Bohinski, 2001 [5]

mean total $16 \mathrm{~m}$

$\mathrm{T} 1, \mathrm{~T} 2$

NS

Nimsky, 2003 [36]

NS

T1, FLAIR, other

NS

Hirschberg, 2005 [19] NS

$\mathrm{T} 1$

$1,6 \mathrm{~h}$

Schneider, 2005 [52] NS

T1, T2, other

NS

Busse, 2006 [7]

NS

T1, other

$13 \mathrm{~m}$ for "advanced navigation"

Muragaki, 2006 [35] NS

T1, T2

NS

Nimsky, 2006 [41]

circa $73 m$ per

T1, T2, FLAIR, other

NS

procedure

Hatiboglu, 2009 [18] NS

T1, T2, FLAIR, othe

NS

Lenaburg, 2009 [27]

$13,5 \mathrm{~m}$ average

$\mathrm{T} 1, \mathrm{~T} 2$

NS

Senft, 2010 [57]

NS

$\mathrm{T1}$

NS

Abbreviations: FLAIR = Fluid Attenuated Inversion Recovery, Gd-dimeg = gadopentetate dimeglumine, Gd-DTPA = gadolinium Diethylene Triamine Pentaacetic Acid, $h=$ hours, $m=$ minutes, NS = Not Specified, $O R=$ Operating Room, $T=$ the magnet's field strength in Tesla

* Derived from other study, which was excluded for overlapping data,(REF: Nimksy2004 beide) because the included study did not specify this information. 


\begin{tabular}{|c|c|c|c|c|c|}
\hline \multirow[t]{2}{*}{ Reference } & \multicolumn{5}{|c|}{ Gross Total Resection } \\
\hline & Definition & Volumetry & Intended & 1st iMRI & Last iMRI \\
\hline $\begin{array}{l}\text { Knauth, } \\
1999 \text { [22] }\end{array}$ & NS & No & in $100 \%$ & $37 \%$ & $\begin{array}{l}\text { not performed } \\
\text { (76\% GTR on EPMRI) }\end{array}$ \\
\hline $\begin{array}{l}\text { Wirtz, } 2000 \\
\text { [65] }\end{array}$ & $\begin{array}{l}\text { removal of CE on } \\
\text { iMRI evaluated by } \\
\text { neurosurgeon }\end{array}$ & No & NS & in $27 \%$ of $\mathrm{HGG}$ & $\begin{array}{l}\text { in } 67 \% \text { of } \mathrm{HGG} \text { resection } \\
\text { continued } \\
\text { (no final iMRI result } \\
\text { available) }\end{array}$ \\
\hline $\begin{array}{l}\text { Bohinski, } \\
2001 \text { [5] }\end{array}$ & $\begin{array}{l}\text { opinion } \\
\text { neuroradiologist } \\
\text { and neurosurgeon }\end{array}$ & No & $\begin{array}{l}\text { NSSub } \\
\text { ("in 30/40 } \\
\text { gliomas") }\end{array}$ & $\begin{array}{l}\text { additional } \\
\text { resection in } \\
60 \% \text { of } \mathrm{HGG}\end{array}$ & NS \\
\hline $\begin{array}{l}\text { Nimsky, } \\
2003[36]\end{array}$ & $\begin{array}{l}\text { evaluation (by } \\
\text { neurosurgeon?) }\end{array}$ & No & NSSub & $6 / 32 \mathrm{pt}$ & $7 / 32 \mathrm{pt}$ \\
\hline $\begin{array}{l}\text { Hirschberg } \\
, 2005 \text { [19] }\end{array}$ & $\begin{array}{l}\text { opinion } \\
\text { neurosurgeon and } \\
\text { neuroradiologist }\end{array}$ & No & $\begin{array}{l}\text { NS } \\
\text { (seems to } \\
\text { be19/27 } \\
\text { pt) }\end{array}$ & $5 / 27 \mathrm{pt}$ & NS \\
\hline $\begin{array}{l}\text { Schneider, } \\
2005 \text { [52] }\end{array}$ & $\begin{array}{l}>95 \% \text { removal of } \\
\text { CE (with necrosis) } \\
\text { on } \mathrm{T} 1 \mathrm{Gd} \\
\text { measured by } \\
\text { segmentation }\end{array}$ & $\begin{array}{l}\text { Yes: sum } \\
\text { of tumor } \\
\text { area per } \\
\text { slice x } \\
\text { slice } \\
\text { thickness } \\
\text { (+ gap } \\
\text { thickness) }\end{array}$ & NS & $2 / 31 \mathrm{pt}$ & $11 / 31 \mathrm{pt}$ \\
\hline $\begin{array}{l}\text { Busse, } \\
2006 \text { [7] }\end{array}$ & $\begin{array}{l}\text { consensus } \\
\text { neurosurgeon }+ \\
\text { neuroradiologist }\end{array}$ & No & NS & NS & 4 GBM had "total" resection \\
\hline $\begin{array}{l}\text { Muragaki, } \\
2006 \text { [35] }\end{array}$ & $\begin{array}{l}\text { removal of CE on } \\
\text { T1Gd measured } \\
\text { by segmentation }\end{array}$ & $\begin{array}{l}\text { Yes: sum } \\
\text { of tumor } \\
\text { area per } \\
\text { slice x } \\
\text { slice } \\
\text { thickness }\end{array}$ & NS & NS & $90 \%$ EOTR \\
\hline
\end{tabular}


Table 2.4 (continued): Study population and resection parameters of included studies*

Reference

$\begin{array}{ll} & \text { Definition } \\ \text { Nimsky, } & \text { NS } \\ 2006[41] & \\ \text { Hatiboglu, } & >95 \% \text { EOTR } \\ 2009[18] & (=\text { CE onT1Gd })\end{array}$

Gross Total Resection

Volumetry
$\mathrm{No}^{\star \star}$

Intended 1st iMRI

Last iMRI

at least $\quad 16 / 57 \mathrm{pt}$

23/57 pt

not in

25/57 pt

Yes: tumor

NS

$12 / 27 \mathrm{pt}$

24/27 pt

area on

Vitrea by 2

neurosurgeo

ns

Lenaburg, mathematical 2009 [27] model

Yes: $4 / 3 \times \pi \quad N S$

$x a \times b \times c$

(a, b and $c$

are

diameters)

Senft, 2010 no residual CE No

seen by

in $100 \%$ NS

NS ("in $72 \%$

$27 / 35$ cases had resection

further

$>95 \%$

resection")

[57]

neuroradiologist

(blinded for

treatment group)

Abbreviations: $\mathrm{cNN}=$ Conventional Neuronavigation, $\mathrm{CE}=$ Contrast Enhancement, $\mathrm{CSF}=$ Cerebrospinal Fluid, $d=$ days, $D=$ Deteriorated clinical performance, EOTR $=$ Extent Of Tumor Resection, EPMRI = Early Postoperative MRI, GBM = Glioblastoma Multiforme, GTR = Gross Total Resection, HGG = High Grade Glioma, I = Improved clinical performance, incl rec $=$ including recurrences, $i M R I=I n$ traoperative $M R I, m=$ months, $N S=$ Not Specified, NSSub $=$ Not Specified for this subpopulation (in contrast to total study cohort), pt = patients, STR = Subtotal Resection, $T 1 \mathrm{Gd}=T 1$-weighted MRI after gadolinium administration, $U=$ unchanged clinical performance, vs = versus, $w=$ weeks, $/$ (forward slash) = "out of"

* If possible, only data on GBM were used (derived from text, tables or figures). If not available, data for HGG were used.

* * In a smaller study on volumetric assessment of glioma removal (excluded for overlapping data) the authors performed volumetry by applying manual segmentation on the VectorVision workstation, using co-registration of all imaging data sets.

* * * originally 32 GBMs were operated for this study, but only 27 were described to have good image quality and were used for further analysis 
Table 2.4 (continued): Study population and resection parameters of included studies*

\begin{tabular}{|c|c|c|c|}
\hline Reference & $n$ & $\begin{array}{l}\text { Clinical } \\
\text { performance }\end{array}$ & Complications \\
\hline $\begin{array}{l}\text { Knauth, } 1999 \\
{[22]}\end{array}$ & $\begin{array}{l}41 \mathrm{HGG} \\
\text { in } 38 \mathrm{pt}\end{array}$ & NS & NS \\
\hline $\begin{array}{l}\text { Wirtz, } 2000 \\
{[65]}\end{array}$ & $\begin{array}{l}68 \text { HGG } \\
\text { incl rec } \\
\text { (62 GBM) }\end{array}$ & NSSub & NSSub \\
\hline $\begin{array}{l}\text { Bohinski, } \\
2001 \text { [5] }\end{array}$ & $30 \mathrm{HGG}$ & NSSub & NSSub \\
\hline $\begin{array}{l}\text { Nimsky, } 2003 \\
{[36]}\end{array}$ & 32 GBM & NSSub & NSSub \\
\hline
\end{tabular}

Hirschberg, $32 \quad$ I $16 \% \cup 55 \%$ D 2 infections mean $14,5 \mathrm{~m}$ vs $12,1 \mathrm{~m}$ for 2005 [19] GBM $^{\star \star *} \quad 29 \% \quad 3$ visual field defects matched control group without iMRI $(p=0,14)$

Schneider, 31 GBM D 13\% $\quad 1$ rebleed;1 edema; median 537d for GTR vs 2005 [52]

2 new paresis $237 d$ for STR $(p=0,004)$

Busse, 2006

24 GBM NSSub

NSSub

NS

[7] incl rec

Muragaki, $\quad 30$ GBM NSSub

NSSub

NS

2006 [35]

Nimsky, 200657 GBM NSSub

NSSub

NS

[41]

Hatiboglu,

27 GBM NSSub

NSSub

NS

Lenaburg,

35 GBM

D 1/35 cases

1 respiratory failure

NS

2009 [27]

in $29 \mathrm{pt}$

(died); 2 wound

infections leading to wound revision' 1

CSF leak

Senft, 2010 41 GBM NS NS

[57]

median $74 \mathrm{w}$ for GTR vs $46 \mathrm{w}$ for STR $(p<0,001)$;

$88 \mathrm{w}$ for iMRI vs $68 \mathrm{w}$ for $\mathrm{cNN}$ $(p=0,07)$ 


\section{DISCUSSION}

\section{Summary of evidence}

This review aims to provide a qualitative synthesis of the literature on the added value of iMRI-guided resection of glioblastoma compared to cNN with respect to EOTR, quality of life, and survival. Many studies have been published on this topic, but they suffer from serious limitations like heterogeneity in study populations and technical equipment, attribution bias, and different methods to assess EOTR. These and other limitations will be discussed in detail in the next paragraphs.

\section{Limitations}

\section{Population heterogeneity}

Frequently study populations are very heterogeneous regarding to pathological diagnosis, and often outcome parameters are not stratified for this heterogeneity. Many papers are excluded in this review for that reason. $[3,54,2,11,20,29,32,34,50,55,53,66]$ Even in a glioma subpopulation such stratification is mandatory. Different types and WHO grades differ significantly in macroscopical and sometimes MRI appearance, and survival. This influences outcome parameters related to iMRI-guided surgery. While the excluded papers can be very informative in providing background information on iMRIguided surgery, they can not be used to answer our search question.

\section{Overlapping data}

The second most frequent reason to exclude papers for this review was overlapping patient data. $[40,45,44,58,37,59,63]$ Multiple papers about the same cohort can offer valuable insights from various points of view. On the other hand, results for EOTR or survival can only be used once in data collection when performing a literature review. As a consequence of both population heterogeneity and overlapping data, the net amount of literature that contributes to establish evidence is limited.

\section{Attribution bias}

Because patients with a high grade glioma have limited survival expectancy, the neurosurgeon is careful to avoid additional brain damage ("do no harm" principle). When the neurosurgeon is in doubt 
about possible tumor remnants around the resection cavity, resection is stopped and an iMRI scan is made. In our experience iMRI-guided surgery leads to a more conservative resection before the first intraoperative control scan is made. From informal conversations we understood this situation is comparable in several other centers.

This principle is important when interpreting studies on iMRI-guided resection. Often the conclusion is that an increased EOTR after intraoperative scanning is achieved. Bias arises when this increased EOTR is attributed to the use of iMRI. This refers to another principle: "post hoc ergo propter hoc?" ("after which, so because of?"). Without the availability of intraoperative resection control, the neurosurgeon might be more aggressive to prevent unintended postoperative tumor remnants or even a second procedure for additional resection. Therefore the effect of iMRI in increasing EOTR may be overestimated. It is unknown to what extent this attribution bias is related to the surgical and iMRI experience of the neurosurgeon. The only way to prevent this attribution bias is performing a randomized trial, which has not been done to date.

\section{Assessment of EOTR}

In the 12 selected studies there are at least 5 different descriptions for GTR, if it is defined explicitly at all (Table 2.4). Essentially there are two approaches used: qualitative (presence of contrast enhancement on T1-weighted MRI) or quantitative (volumetric assessment by manual segmentation). The first method is a rough method that dichotomizes GTR between "yes" and "no". The second method has the theoretical advantage of a higher precision, but has an unacceptable low interobserver agreement for postoperative images (intraclass correlation coefficient $=0.54$ ) to serve as a valid method to assess EOTR.[25] The MacDonald criteria,[31] Response Evaluation Criteria In Solid Tumors (RECIST)[62] and Response Assessment in Neuro-Oncology criteria (RANO)[64] are all not useful for postoperative tumor size assessment because they require an approximately spherical tumor. This is clearly not the case for contrast enhancement at the border of the resection cavity. Reliable and validated criteria to assess EOTR are necessary to compare the results of neurosurgical studies. In our opinion, an intraclass correlation coefficient of at least 0.8 is required to allow comparison of results between different studies.

\section{Different field strengths}

Regarding iMRI a distinction is made between low-field strength ( $\leq 0.5$ Tesla) and high-field strength ( $\geq 1.5$ Tesla) devices. The field strength of an iMRI system is directly related to the spatial resolution of the images. Therefore, image quality on high-field strength devices is better than on low-field strength devices. This may influence the results, although the small number of studies included for this review showed no evidence for this. 
Besides offering a higher spatial resolution, high-field strength systems are capable of offering several imaging modalities that are hard or pratically impossible to acquire on low-field strength systems. Acquisition of functional MR images has been reported on low-field strength systems,[1] but fiber tracking using Diffusion Tensor Imaging or MR spectroscopy has only been reported on highfield strength MRI so far.[43] The possibility to use such additional imaging sequences in combination with higher spatial resolution has to be balanced against the significantly higher cost of purchasing and maintaining this equipment. The amount and type of iMRI surgeries that will be performed will be an important factor in these considerations, as well as the associated research opportunities and the possibilities for using a high-field strength system for diagnostic imaging in non-surgical cases.

\section{Contrast agent}

The application of contrast agent differs between studies, and two parameters may be important: dose and timing. First, the required dose may be related to the magnet's field strength. A so-called "double dose" of contrast agent $(0.2 \mathrm{mmol} / \mathrm{kg})$ for low-field strength scanning is said to be comparable to a "single dose" $(0.1 \mathrm{mmol} / \mathrm{kg})$ for high-field strength scanning.[21] Second, the timing of contrast administration will influence the amount of residual enhancement. When contrast agent is administered at the beginning of surgery, a part will still be present when performing the first intra-operative scan. Variation in presence of residual contrast agent may lead to variation in contrast enhancement, which can be difficult to distinguish from residual tumor.[17,23] Recently it has been advocated to wait with contrast administration until the first intra-operative scan, to avoid confusion between residual and new contrast enhancement.[23] Especially earlier studies in which contrast agent was administered both before surgery and before the first resection control scan might overestimate the amount of tumor resection: part of the resected tissue will be this residual enhancement on the intraoperative scan. Even though some authors sent the additionally resected tissue for separate histological diagnosis, $[51,52,36,33]$ the "presence of tumor cells" does not exclude that more tissue has been resected than intended, based on the preoperative MRI.

\section{Quality of life and survival}

Only 3 out of 12 studies provided explicit data on clinical performance, and no studies provided data on quality of life. This is an important topic that needs more attention in future studies. Increased EOTR should be weighed against clinical performance and quality of life, since low frequent postoperative deficits might be more important in regard to survival and quality of life than increasing the EOTR with several percentiles A subset of 3 out of 12 studies reported on statistically significant prolonged survival in the GTR group compared to the group that had subtotal resection. However, in 2 of these 3 studies, all patients were operated with iMRI, so the additional value of iMRI remains unclear and in the other study a non-randomized mix of iMRI and cNN cases was reported with the potential 
of substantial bias. In all cases no inference could be made between use of iMRI and increased survival.

\section{Other limitations}

Another frequently occurring limitation is that control groups may not be equivalent to study groups.[14,58,19] This concerns mainly tumor location and different navigation systems (historic control group that was operated with earlier navigation systems). Tumor location is of prominent importance, since the EOTR is directly related to the eloquence of the tumor location. Also the time points when clinical performance is measured varies between studies (before discharge or at three months after surgery). This makes a valid comparison of the results difficult.

A further issue of concern is the definition of tumor volume. Defining glioblastoma as the contrast enhancing area on T1-weighted MRI is common practice. Although phenomena as pseudoprogression[64] and pseudo-enhancement[64] are not applicable to an early postoperative MRI within 72 hours after surgery, it is questionable whether the volume to be resected is best defined by contrast enhancement. New imaging techniques may allow for other (and maybe better) methods to visualize glioblastoma volume, like MR perfusion or MR spectroscopy. This translates to an issue of concern for the future use of $\mathrm{iMRI}$, as only high-field strength iMRI systems are currently able to provide such image modalities with acceptable quality within an acceptable time span.

\section{Recommendations for future research}

Based on the results of this systematic review there are a few recommendations for future studies on iMRI-guided glioblastoma resection. First, if residual tumor volume or resection percentage is to be used as a primary endpoint, it is mandatory to have a clear definition of postoperative tumor volume and a valid method to measure this. Currently volumetry cannot serve as a valid endpoint, mainly due to unacceptable low interobserver agreement for postoperative tumor volume and, therefore, residual tumor volume.

Second, (more) randomized comparisons between different types of image-guided surgery seem to be in place. Besides $\mathrm{iMRI}$ these include intraoperative ultrasound, intraoperative CT and fluorescence-guided surgery with 5-aminolevulinic acid (5-ALA). Particularly the latter has been demonstrated to enable more complete resections of contrast-enhancing tumor, leading to improved progression-free survival in patients with malignant glioma.[60] A relatively small phase II study could explore which technique brings the best GTR rate. A more fundamental question is whether 5-ALA guided surgery should not be implemented first, knowing that this improves EOTR for malignant glioma. iMRI can then be added and compared to this proven technique. Of note, the implementation 5-ALA is considered to be more simple and less costly for this type of tumors. 
Third, outcome data should be more detailed, not only including clinical performance (from a physician's standpoint) but also quality of life data (from a patient's standpoint). Such data should be weighed against EOTR and survival to find a balance that may be considered as optimal treatment for glioblastoma patients. For this patient population maximizing EOTR might be less helpful than maximizing quality of life. Quality Adjusted Life Years (QALYs) are an excellent outcome parameter to measure this, and allow for comparison between different types of treatment (both non-surgical and surgical).

Fourth, more studies on cost-benefit for iMRI are welcomed. There are only a few studies dealing with this issue, reporting on a mixed patient population.[14,24,26] As iMRI is an expensive technique, economic justification is an issue of concern. 


\section{CONCLUSION AND SUGGESTIONS}

Based on the available literature there is currently at best level 2 evidence that iMRI-guided surgery is more effective than cNN-guided surgery in (significantly) increasing EOTR, enhancing quality of life or prolonging survival in glioblastoma patients. Higher quality studies on iMRI are necessary to demonstrate its added value compared to standard treatment. If EOTR is to be used as a primary endpoint, we need a clear definition on postoperative tumor volume and a valid method to measure this volume. For the future it will become more important to weigh this added value against the cost, for example using QALYs (Quality Adjusted Life Years) as an outcome parameter. Social and economical forces oblige us to perform better quality research in order to offer the best possible treatment to our patients while keeping healthcare affordable. A randomized trial with validated endpoints is necessary to demonstrate the actual added value of iMRI-guided surgery. 


\section{REFERENCES}

1. Azmi H, Biswal B, Salas S, Schulder M. Functional imaging in a low-field, mobile intraoperative magnetic resonance scanner: expanded paradigms. Neurosurgery 2007; 60:143-8; discussion 1489.

2. Bergsneider M, Sehati N, Villablanca P, McArthur DL, Becker DP, Liau LM. Mahaley Clinical Research Award: extent of glioma resection using low-field (0.2 T) versus high-field (1.5 T) intraoperative MRI and image-guided frameless neuronavigation. Clinical neurosurgery 2005; 52:389-399.

3. Black PM, Alexander E, Martin C, Moriarty T, Nabavi A, Wong TZ, et al. Craniotomy for tumor treatment in an intraoperative magnetic resonance imaging unit. Neurosurgery 1999; 45:423-31- discussion 431-3.

4. Black PM, Moriarty T, Alexander E, Stieg P, Woodard EJ, Gleason PL, et al. Development and implementation of intraoperative magnetic resonance imaging and its neurosurgical applications. Neurosurgery 1997; 41:831-42- discussion 842-5.

5. Bohinski RJ. Glioma Resection in a Shared-resource Magnetic Resonance Operating Room after Optimal Image-guided Frameless Stereotactic Resection. Neurosurgery 2001;:14.

6. Bohinski RJ. Intraoperative Magnetic Resonance Imaging to Determine the Extent of Resection of Pituitary Macroadenomas during

Transsphenoidal Microsurgery. Neurosurgery 2001;:12.

7. Busse H, Schmitgen A, Trantakis C, Schober R, Kahn T, Moche M. Advanced approach for intraoperative MRI guidance and potential benefit for neurosurgical applications. J Magn Reson Imaging 2006; 24:140-151.

8. Claus EB, Horlacher A, Hsu L, Schwartz RB, Dello-lacono D, Talos F, et al. Survival rates in patients with low-grade glioma after intraoperative magnetic resonance image guidance. Cancer 2005; 103:1227-1233.

9. Fahlbusch R, Thapar K. New developments in pituitary surgical techniques. Baillieres Best Pract Res Clin Endocrinol Metab 1999; 13:471-484.

10. Fujii M, Wakabayashi T. [Image-guided neurosurgery using intraoperative MRI]. Brain Nerve 2009; 61:823-834. 
11. Ganslandt O, Behari S, Gralla J, Fahlbusch R, Nimsky C. Neuronavigation: concept, techniques and applications. Neurol India 2002; 50:244-255.

12. Gerlach R, Mesnil de Rochemont du R, Gasser T, Marquardt G, Reusch J, Imoehl L, et al. Feasibility of Polestar N20, an ultra-low-field intraoperative magnetic resonance imaging system in resection control of pituitary macroadenomas: lessons learned from the first 40 cases. Neurosurgery 2008; 63:272-84; discussion 284-5.

13. Hadani M. Novel, Compact, Intraoperative Magnetic Resonance Imaging-guided System for Conventional Neurosurgical Operating Rooms. Neurosurgery 2001;:11.

14. Hall WA, Kowalik K, Liu H, Truwit CL, Kucharezyk J. Costs and benefits of intraoperative MRguided brain tumor resection. Acta Neurochir Suppl 2003; 85:137-142.

15. Hall WA, Liu H, Martin AJ, Pozza CH, Maxwell RE, Truwit CL. Safety, efficacy, and functionality of high-field strength interventional magnetic resonance imaging for neurosurgery. Neurosurgery 2000; 46:632-41; discussion 641-2.

16. Hall WA, Galicich W, Bergman T, Truwit CL. 3-Tesla intraoperative MR imaging for neurosurgery. J Neurooncol 2006; 77:297-303.

17. Hall WA, Truwit CL. Intraoperative MR-guided neurosurgery. J Magn Reson Imaging 2008; 27:368-375.

18. Hatiboglu MA, Weinberg JS, Suki D, Rao G, Prabhu SS, Shah K, et al. Impact of intraoperative high-field magnetic resonance imaging guidance on glioma surgery: a prospective volumetric analysis. Neurosurgery 2009; 64:1073-81; discussion 1081.

19. Hirschberg H, Samset E, Hol PK, Tillung T, Lote K. Impact of intraoperative MRI on the surgical results for high-grade gliomas. Minim Invasive Neurosurg 2005; 48:77-84.

20. Jankovski A, Francotte F, Vaz G, Fomekong E, Duprez T, Van Boven M, et al. Intraoperative magnetic resonance imaging at 3-T using a dual independent operating room-magnetic resonance imaging suite: development, feasibility, safety, and preliminary experience. Neurosurgery 2008; 63:41224; discussion 424-6.

21. Knauth M, Wirtz CR, Aras N, Sartor K. Low-field interventional MRI in neurosurgery: finding the right dose of contrast medium. Neuroradiology 2001; 43:254-258.

22. Knauth M. Intraoperative MR Imaging Increases the Extent of Tumor Resection in Patients with High-Grade Gliomas. AJNR 1999;:5.

23. Knauth M. Surgically Induced Intracranial Contrast Enhancement: Potential Source of Diagnostic Error in Intraoperative MR Imaging. AJNR 1999;:7. 
24. Kowalik K, Truwit C, Hall W, Kucharczyk J. Initial assessment of costs and benefits of MRI-guided brain tumor resection. Eur Radiol 2000; 10 Suppl 3:S366-7.

25. Kubben PL, Postma AA, Kessels AGH, van Overbeeke JJ, van Santbrink H. Intraobserver and interobserver agreement in volumetric assessment of glioblastoma multiforme resection. Neurosurgery 2010; 67:1329-1334.

26. Kucharczyk W, Bernstein M. Do the Benefits of Image Guidance in Neurosurgery Justify the Costs? From Stereotaxy to Intraoperative MR. AJNR 1997;:5.

27. Lenaburg HJ, Inkabi KE, Vitaz TW. The use of intraoperative MRI for the treatment of glioblastoma multiforme. Technol Cancer Res Treat 2009; 8:159-162.

28. Levivier M, Wikler D, De Witte O, De Steene Van A, Bal Riaux D, Brotchi J. PoleStar N-10 Low-field Compact Intraoperative Magnetic Resonance Imaging System with Mobile Radiofrequency Shielding. Neurosurgery 2003;:1001-1007.

29. Lewin JS, Nour SG, Meyers ML, Metzger AK, Maciunas RJ, Wendt M, et al. Intraoperative MRI with a Rotating, Tiltable Surgical Table: A Time Use Study and Clinical Results in 122 Patients. American Journal of Roentgenology 2007; 189:1096-1103.

30. Liberati A, Altman DG, Tetzlaff J, Mulrow C, Gøtzsche PC, loannidis JPA, et al. The PRISMA statement for reporting systematic reviews and meta-analyses of studies that evaluate health care interventions: explanation and elaboration. PLoS Med 2009; 6:e1000100.

31. Macdonald DR, Cascino TL, Schold SC, Cairncross JG. Response criteria for phase II studies of supratentorial malignant glioma. J Clin Oncol 1990; 8:1277-1280.

32. Maesawa S, Fujii M, Nakahara N, Watanabe T, Saito K, Kajita Y, et al. Clinical indications for highfield 1.5 $\mathrm{T}$ intraoperative magnetic resonance imaging and neuro-navigation for neurosurgical procedures. Review of initial 100 cases. Neurol Med Chir (Tokyo) 2009; 49:340-9; discussion 349-50.

33. Martin AJ, Hall WA, Liu H, Pozza CH, Michel E, Casey SO, et al. Brain tumor resection: intraoperative monitoring with high-field-strength MR imaging-initial results. Radiology 2000; 215:221-228.

34. McPherson CM, Bohinski RJ, Dagnew E, Warnick RE, Tew JM. Tumor resection in a sharedresource magnetic resonance operating room: experience at the University of Cincinnati. Acta Neurochir Suppl 2003; 85:39-44.

35. Muragaki $Y$, Iseki H, Maruyama T, Kawamata T, Yamane F, Nakamura R, et al. Usefulness of intraoperative magnetic resonance imaging for glioma surgery. Acta Neurochir Suppl 2006; 98:67-75.

36. Nimsky C, Ganslandt O, Buchfelder M, Fahlbusch R. Glioma surgery evaluated by intraoperative low-field magnetic resonance imaging. Acta Neurochir Suppl 2003; 85:55-63. 
37. Nimsky C, Ganslandt O, Keller von B, Fahlbusch R. Preliminary experience in glioma surgery with intraoperative high-field MRI. Acta Neurochir Suppl 2003; 88:21-29.

38. Nimsky C. Intraoperative Magnetic Resonance Imaging Combined with Neuronavigation: A New Concept. Neurosurgery 2001;:10.

39. Nimsky C. Quantification of, Visualization of, and Compensation for Brain Shift Using Intraoperative Magnetic Resonance Imaging. Neurosurgery 2000;:11.

40. Nimsky C, Fujita A, Ganslandt O, Keller Von B, Fahlbusch R. Volumetric Assessment of Glioma Removal by Intraoperative High-field Magnetic Resonance Imaging. Neurosurgery 2004;:358-371.

41. Nimsky C, Ganslandt O, Buchfelder M, Fahlbusch R. Intraoperative visualization for resection of gliomas: the role of functional neuronavigation and intraoperative $1.5 \mathrm{~T}$ MRI. Neurol Res 2006; 28:482-487.

42. Nimsky C, Ganslandt O, Fahlbusch R. Comparing 0.2 tesla with 1.5 tesla intraoperative magnetic resonance imaging analysis of setup, workflow, and efficiency. Academic Radiology 2005; 12:10651079 .

43. Nimsky C, Ganslandt O, Fahlbusch R. Implementation of fiber tract navigation. Neurosurgery 2006; 58:ONS-292-303; discussion ONS-303-4.

44. Nimsky C, Ganslandt O, Keller Von B, Romstöck J, Fahlbusch R. Intraoperative high-field-strength MR imaging: implementation and experience in 200 patients. Radiology 2004; 233:67-78.

45. Nimsky C, Ganslandt O, Tomandl B, Buchfelder M, Fahlbusch R. Low-field magnetic resonance imaging for intraoperative use in neurosurgery: a 5-year experience. Eur Radiol 2002; 12:2690-2703.

46. Nimsky C, Keller Von B, Ganslandt O, Fahlbusch R. Intraoperative high-field magnetic resonance imaging in transsphenoidal surgery of hormonally inactive pituitary macroadenomas. Neurosurgery 2006; 59:105-14; discussion 105-14.

47. Nimsky C, Keller Von B, Schlaffer S, Kuhnt D, Weigel D, Ganslandt O, et al. Updating navigation with intraoperative image data. Topics in magnetic resonance imaging : TMRI 2009; 19:197-204.

48. Ntoukas $\mathrm{V}$. The new generation Polestar N20 for conventional neurosurgical operating rooms: a preliminary report. Neurosurgery ONS 2008;:9.

49. Pergolizzi RS. Intra-Operative MR Guidance During Transsphenoidal Pituitary Resection: Preliminary Results. J Magn Reson Imaging 2001;:6.

50. Ram Z, Hadani M. Intraoperative imaging--MRI. Acta Neurochir Suppl 2003; 88:1-4. 
51. Schneider JP. Gross-total Surgery of Supratentorial Low-grade Gliomas

under Intraoperative MR Guidance. AJNR 2001;:10.

52. Schneider JP, Trantakis C, Rubach M, Schulz T, Dietrich J, Winkler D, et al. Intraoperative MRI to guide the resection of primary supratentorial glioblastoma multiforme-a quantitative radiological analysis. Neuroradiology 2005; 47:489-500.

53. Schulder M. Cranial surgery navigation aided by a compact intraoperative magnetic resonance imager. J Neurosurg 2001;:10.

54. Schulder M. Cranial surgery with an expanded compact intraoperative magnetic resonance imager. J Neurosurg 2006;:7.

55. Schulder M. Intracranial surgery with a compact, low-field-strength magnetic resonance imager. Topics in magnetic resonance imaging : TMRI 2009; 19:179-189.

56. Schwartz TH, Stieg PE, Anand VK. Endoscopic Transsphenoidal Pituitary Surgery with Intraoperative Magnetic Resonance Imaging. Neurosurgery 2006; 58:ONS-44-ONS-51.

57. Senft C, Franz K, Blasel S, Oszvald A, Rathert J, Seifert V, et al. Influence of iMRI-guidance on the extent of resection and survival of patients with glioblastoma multiforme. Technol Cancer Res Treat 2010; 9:339-346.

58. Senft C, Franz K, Ulrich CT, Bink A, Szelényi A, Gasser T, et al. Low field intraoperative MRIguided surgery of gliomas: a single center experience. Clinical neurology and neurosurgery 2010; 112:237-243.

59. Senft C, Seifert V, Hermann E, Franz K, Gasser T. Usefulness of intraoperative ultra low-field magnetic resonance imaging in glioma surgery. Neurosurgery 2008; 63:257-66; discussion 266-7.

60. Stummer W, Pichlmeier U, Meinel T, Wiestler O, Zanella F, Reulen H. Fluorescence-guided surgery with 5-aminolevulinic acid for resection of malignant glioma: a randomised controlled multicentre phase III trial. The Lancet Oncology 2006; 7:392-401.

61. Sutherland GR. A mobile high-field magnetic resonance system for neurosurgery. J Neurosurg $1999 ;: 10$.

62. Therasse P, Arbuck SG, Eisenhauer EA, Wanders J, Kaplan RS, Rubinstein L, et al. New guidelines to evaluate the response to treatment in solid tumors. European Organization for Research and Treatment of Cancer, National Cancer Institute of the United States, National Cancer Institute of Canada. J Natl Cancer Inst 2000; 92:205-216. 
63. Trantakis C, Winkler D, Lindner D, Strauss G, Nagel C, Schneider JP, et al. Clinical results in MRguided therapy for malignant gliomas. Acta Neurochir Suppl 2003; 85:65-71.

64. Wen PY, Macdonald DR, Reardon DA, Cloughesy TF, Sorensen AG, Galanis E, et al. Updated response assessment criteria for high-grade gliomas: response assessment in neuro-oncology working group. J Clin Oncol 2010; 28:1963-1972.

65. Wirtz CR, Knauth M, Staubert A, Bonsanto MM, Sartor K, Kunze S, et al. Clinical evaluation and follow-up results for intraoperative magnetic resonance imaging in neurosurgery. Neurosurgery 2000; 46:1112-20- discussion 1120-2.

66. Yrjänä SK, Tuominen J, Koivukangas J. Intraoperative Magnetic Resonance Imaging in Neurosurgery. SRAD 2007; 48:540-549. 


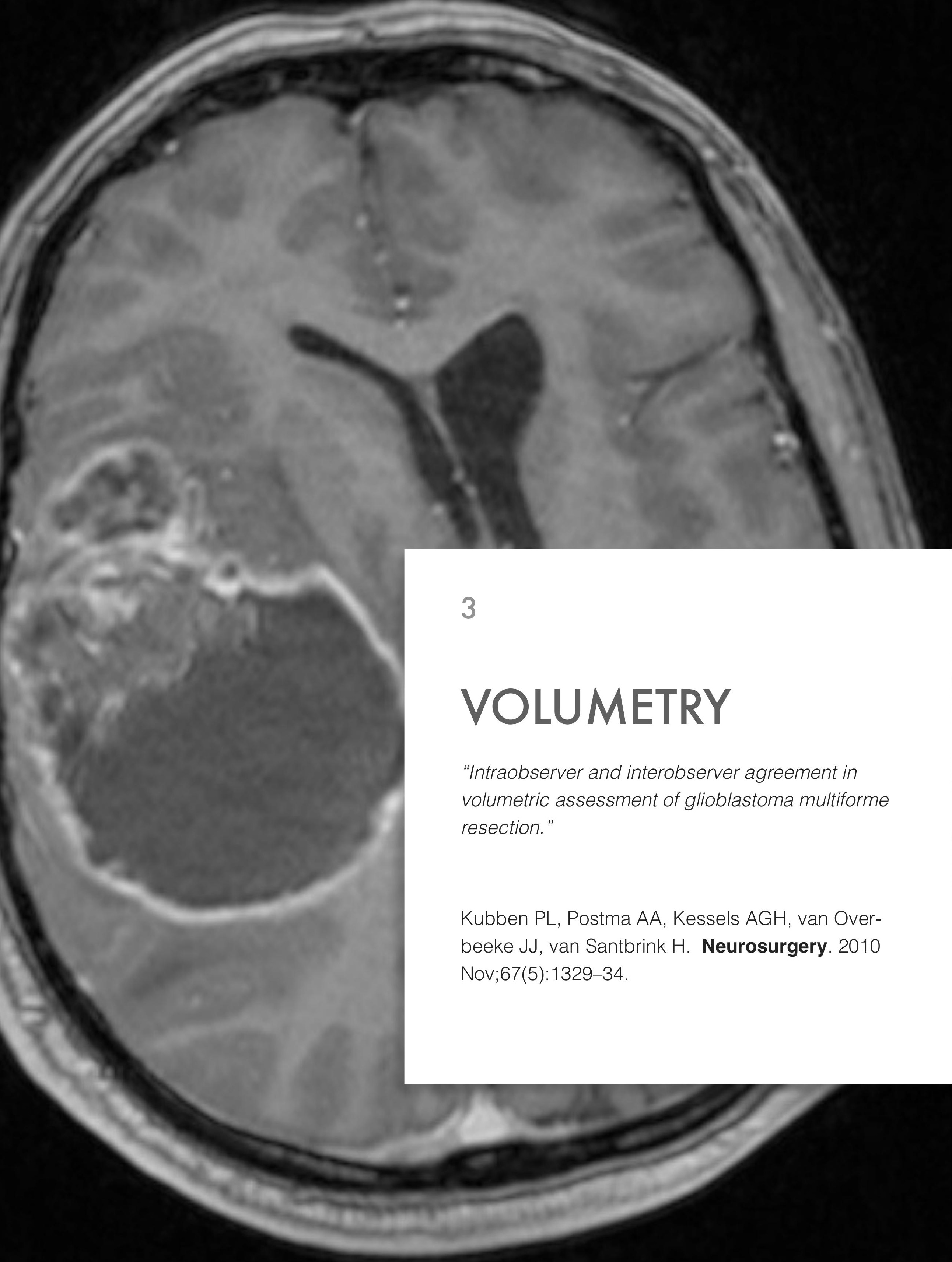




\section{INTRODUCTION}

The role of extent of tumor resection (EOTR) in improving outcome for patients with glioblastoma is still under debate. In a recent review, Sanai et al. concluded that despite persistent limitations in the quality of data, mounting evidence suggests that more extensive surgical resection is associated with longer life expectancy for both low and high grade glioma.[11] Reproducibility of EOTR measurements is important. Several methods have been developed for response assessment of glioma treatment, like the MacDonald criteria and RECIST. $[5,8,17]$ None of these are specific for measuring EOTR. To evaluate the effect of surgical treatment, volumetry may be superior to linear assessment of tumor volume. Three studies reported on EOTR of glioblastoma with volumetry of pre- and postoperative MRI.[6,7,10] Two other studies reported on EOTR of high grade glioma removal with volumetry on intraoperative MRI.[9,12] None of these studies assessed intraobserver or interobserver agreement of this method. The purpose of this study is to analyze both intraobserver and interobserver agreement of manual segmentation as a method for volumetric assessment of glioblastoma resection. 


\section{METHODS}

\section{Patient Selection}

This study was approved by the institutional ethics research board. Imaging data were collected from all patients that were operated in our hospital between April 2007 and April 2008 if they met these inclusion criteria: first brain tumor presentation, histologically proven glioblastoma, presence of a preoperative isovoxel contrast-enhanced $\mathrm{MRI}$, and presence of a postoperative isovoxel contrastenhanced resection control MRI within 72 hours after surgery. A group of 8 patients met these criteria. This group consisted of 5 male and 3 female patients between 48 and 76 years of age (mean age 61 years). The data were prospectively analyzed using the method described later in this section.

\section{Imaging}

MRI scans were made with the Intera 1.5T MRI system (Release 11.1; Philips, Best, The Netherlands). Preoperative and postoperative tumor volumes were measured on contrast-enhanced T1-weighted volumescans (isovoxel $1 \mathrm{~mm}$, gap thickness $0 \mathrm{~mm}$ ). Gadopentetate dimeglumine (Magnevist; BayerSchering Pharma AG, Berlin, Germany) was used as contrast agent in a dose of $0.2 \mathrm{ml} / \mathrm{kg}$. All postoperative scans were performed within 72 hours after surgery.

\section{Expertise of the observers}

The observers are a senior resident in neurosurgery (PK), a neurosurgeon (HvS), and a neuroradiologist (AP). All observers are acquainted with interpreting MRI for brain tumor.

\section{Definition of tumor volume}

For preoperative and postoperative MRI, glioblastoma was defined as the contrast-enhancing mass with enclosed necrosis. Three observers performed manual segmentation of what they considered to be glioblastoma on all slices of both pre- and postoperative MRI. All observers studied all MRI scans twice, with a minimum time interval of two weeks. Each observer was blinded for the results of other observers. Measurements were performed on regular PC's running MS Windows operating system, 
within the Philips iSite-client of our Picture Archiving and Communication System (PACS) (Philips Healthcare Informatics Headquarters, Foster City, CA). Tumor volume (TV) was calculated by summing all segmented slice areas $\left(\mathrm{SA}\right.$, in $\left.\mathrm{cm}^{2}\right)$ within a series, multiplied by the slice thickness $(0.1 \mathrm{~cm})$ :

$\operatorname{TV}\left(\right.$ in $\left.\mathrm{cm}^{3}\right)=\operatorname{sum}(\mathrm{SA}) \times 0.1$

Residual tumor volume percentage (RTV) was calculated by dividing postoperative tumor volume (PostTV) by preoperative tumor volume (PreTV), multiplied by 100\%:

RTV (in \%) $=$ PostTV / PreTV $\times 100$

\section{Statistical analysis}

Intraclass correlation coefficients (ICCs) were calculated using SPSS 16.0.1 for Mac (SPSS Inc, Chicago, IL) by using Reliability Analysis with a one-way random model and $95 \%$ confidence intervals (CI). This was done for intraobserver and interobserver agreement of PreTV, PostTV and RTV. 


\section{RESULTS}

\section{Measurements}

Data from volumetric analysis are displayed in Table 3.1. The rows show the three categories (PreTV, PostTV, RTV) per patient. The columns show the results for each observer. Volumes from first and second measurements are separated by a forward slash.

\section{Time investment for segmentation}

An average manual segmentation of PreTV or PostTV included approximately 40 slices nd took circa 30 minutes each. The required amount of time to analyze one patient once was at least 60 minutes.

\section{Intraobserver agreement}

ICCs with $\mathrm{Cl}$ are displayed in Table 3.2. Intraobserver agreement was high for PreTV (ICC = 0.99), for PostTV and for RTV (ICC = $0.89-0.94)$. The low ICC for PostTV measured by observer 3 (ICC = 0.73) can be explained by patient 8 , in which second PostTV measurements were twice the value of the first measurements. If this patient would be discarded, PostTV ICC for observer 3 is 0.90 .

\section{Interobserver agreement}

Interobserver agreement was high for PreTV $($ ICC $=0.97)$, but low for PostTV $($ ICC $=0.54)$ and RTV (ICC = 0.52). ICCs and Cl for interobserver agreement are also displayed in Table 3.2.

\section{Graphs}

Figures 3.1, 3.2 and 3.3 show the measurements for PreTV, PostTV and RTV respectively. High intraobserver agreement means that all identical symbols (square, triangle or circle) are located closely together. High interobserver agreement means that all symbols are located closely together. Figure 3.1 clearly shows a high intraobserver and interobserver agreement for PreTV, that decreases 
for PostTV (Figure 3.2) and therefore for RTV (Figure 3.3). Figure 3.4 shows that interobserver agreements decreases if PostTV exceeds $20 \mathrm{~cm}^{3}$.

Table 3.1: Data from volumetric analysis of eight patients with three observers Observer 1 Observer 2 Observer 3

\section{Patient 1}

PreTV

PostTV

RTV

\section{Patient 2}

PreTV

PostTV

RTV

Patient 3

PreTV

PostTV

RTV

Patient 4

PreTV

PostTV

RTV

Patient 5

PreTV

PostTV

RTV

Patient 6

PreTV

PostTV

RTV

Patient 7

PreTV

PostTV

RTV
$47.17 / 47.43$

$15.43 / 11.85$

$32.70 / 24.99$

$42.46 / 40.77$

$6.27 / 6.46$

$14.77 / 15.84$

$64.62 / 66.05$

$6.08 / 6.75$

$9.40 / 10.21$

$94.09 / 91.32$

$17.08 / 15.18$

$18.15 / 16.62$

$24.18 / 23.38$

$3.82 / 2.94$

$15.79 / 12.59$

$80.06 / 79.99$

$7.36 / 6.21$

$9.19 / 7.76$

$89.08 / 89.44$

$3.34 / 4.05$

$3.75 / 4.52$
$55.12 / 54.76$

$28.85 / 25.29$

$52.35 / 46.19$

47.04 / 49.31

$32.52 / 28.22$

$69.13 / 57.23$

$77.26 / 79.28$

$13.38 / 13.16$

$17.32 / 16.59$

$120.37 / 117.03$

$43.29 / 31.68$

$35.96 / 27.07$

$28.92 / 30.39$

$10.15 / 11.62$

$35.09 / 38.22$

$88.09 / 87.36$

$10.23 / 13.25$

$11.61 / 15.17$

$99.74 / 96.11$

$15.19 / 16.83$

$15.22 / 17.51$
52.54 / 52.95

$22.14 / 20.24$

$42.13 / 38.22$

46.07 / 46.45

$31.76 / 25.76$

$68.94 / 55.46$

$77.06 / 72.98$

$9.80 / 12.14$

$12.72 / 16.63$

$124.05 / 109.18$

$23.50 / 31.26$

18.94 / 28.63

$27.07 / 27.98$

$5.07 / 7.06$

$18.73 / 25.23$

$84.20 / 86.70$

$12.47 / 12.93$

$14.81 / 14.91$

$96.00 / 99.32$

$15.31 / 16.37$

$15.95 / 16.48$ 
Table 3.1 (continued): Data from volumetric analysis of eight patients with three observers

Observer 1

Patient 8

PreTV

PostTV

RTV
Observer 2

$133.91 / 132.03$
49.27 / 48.82
36.79 / 36.98

Observer 3

$134.54 / 134.83$

$22.73 / 40.55$

$16.89 / 30.07$

Explanation: tumor volumes are expressed in $\mathrm{cm} 3$ and results from first and second measurement are divided by a forward slash. PreTV = preoperative tumor volume; PostTV = postoperatve tumor volume; RTV = residual tumor volume percentage.

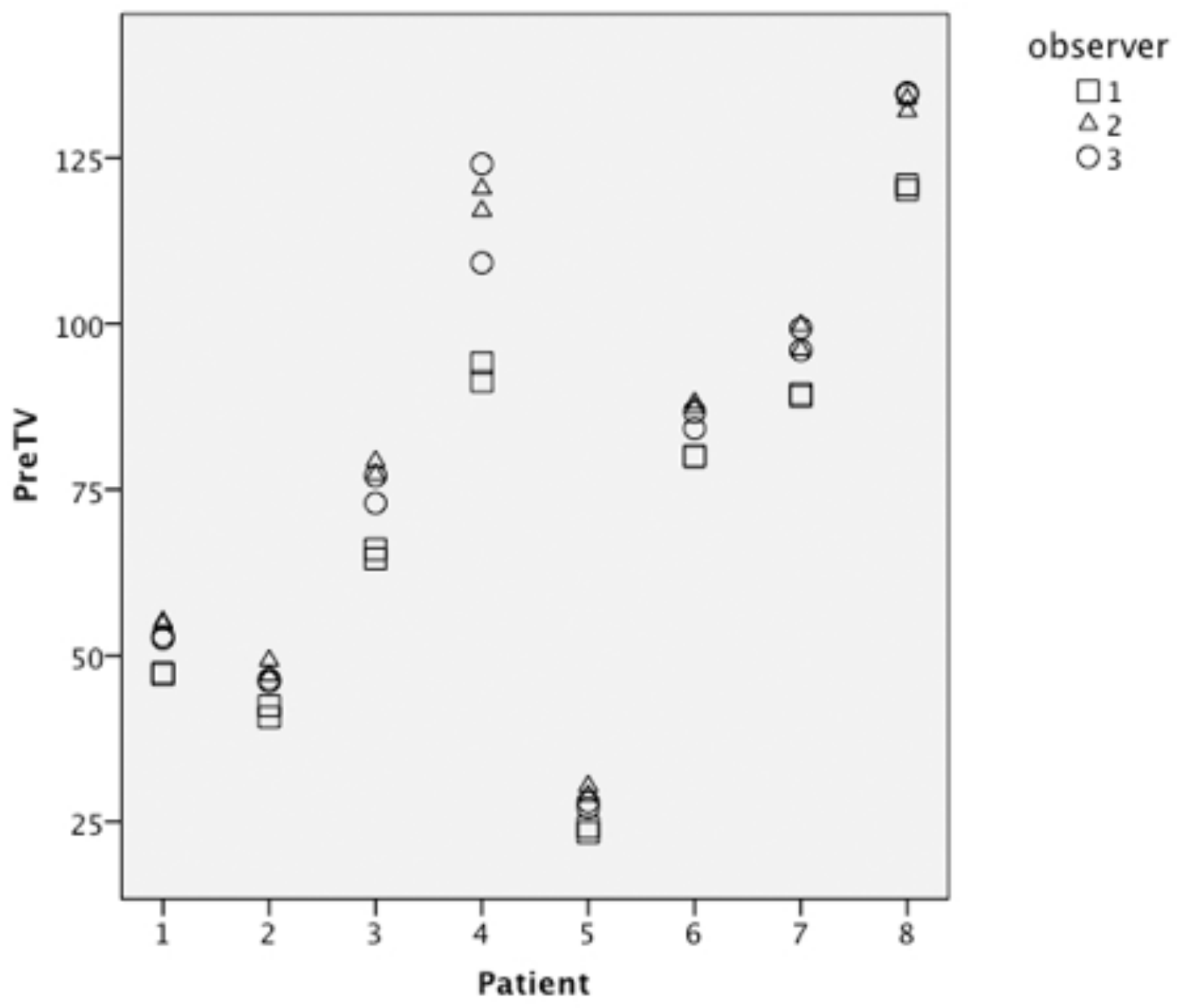

Figure 3.1: PreTV measurements for each observer. 


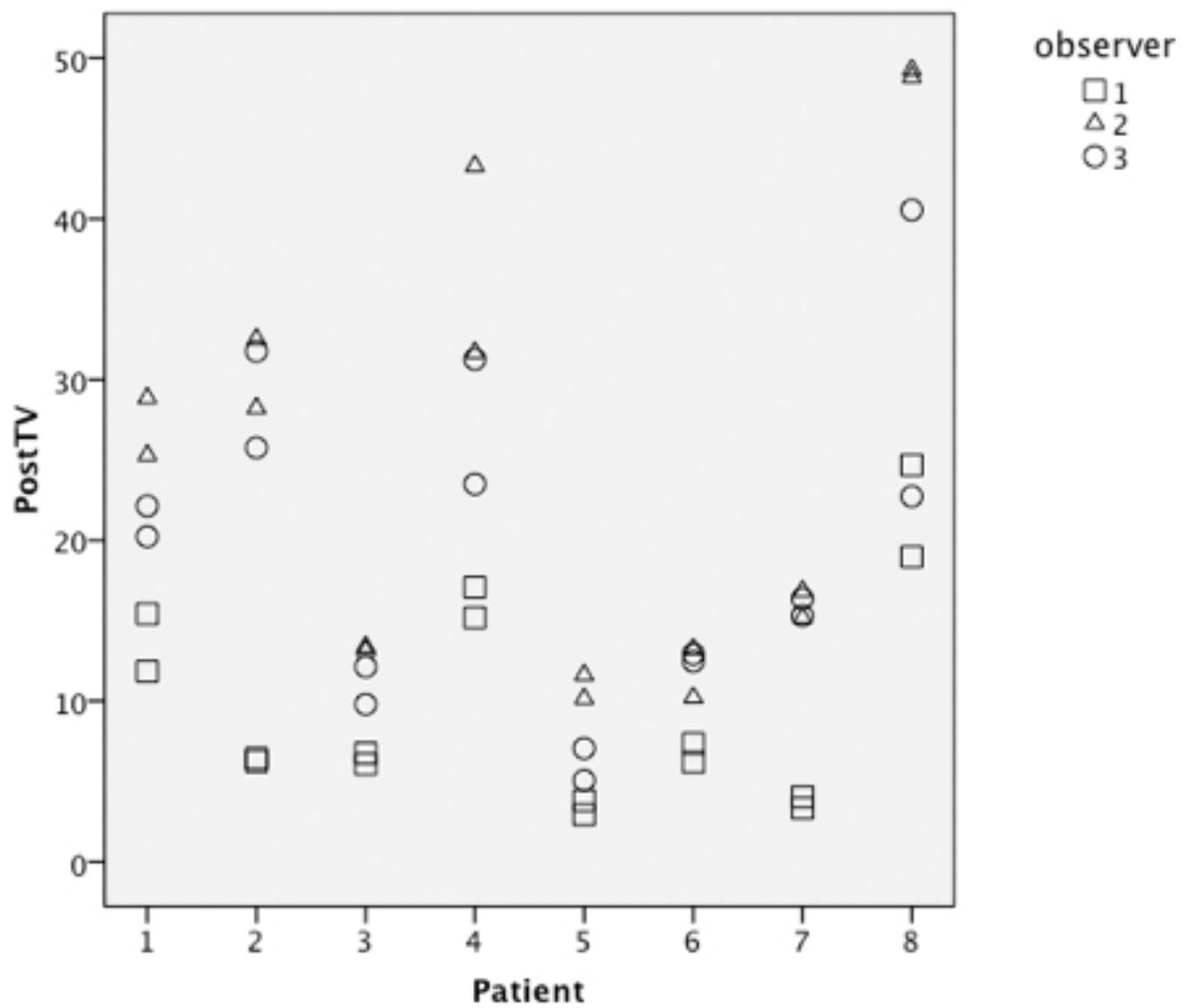

Figure 3.2: PostTV measurements for each observer

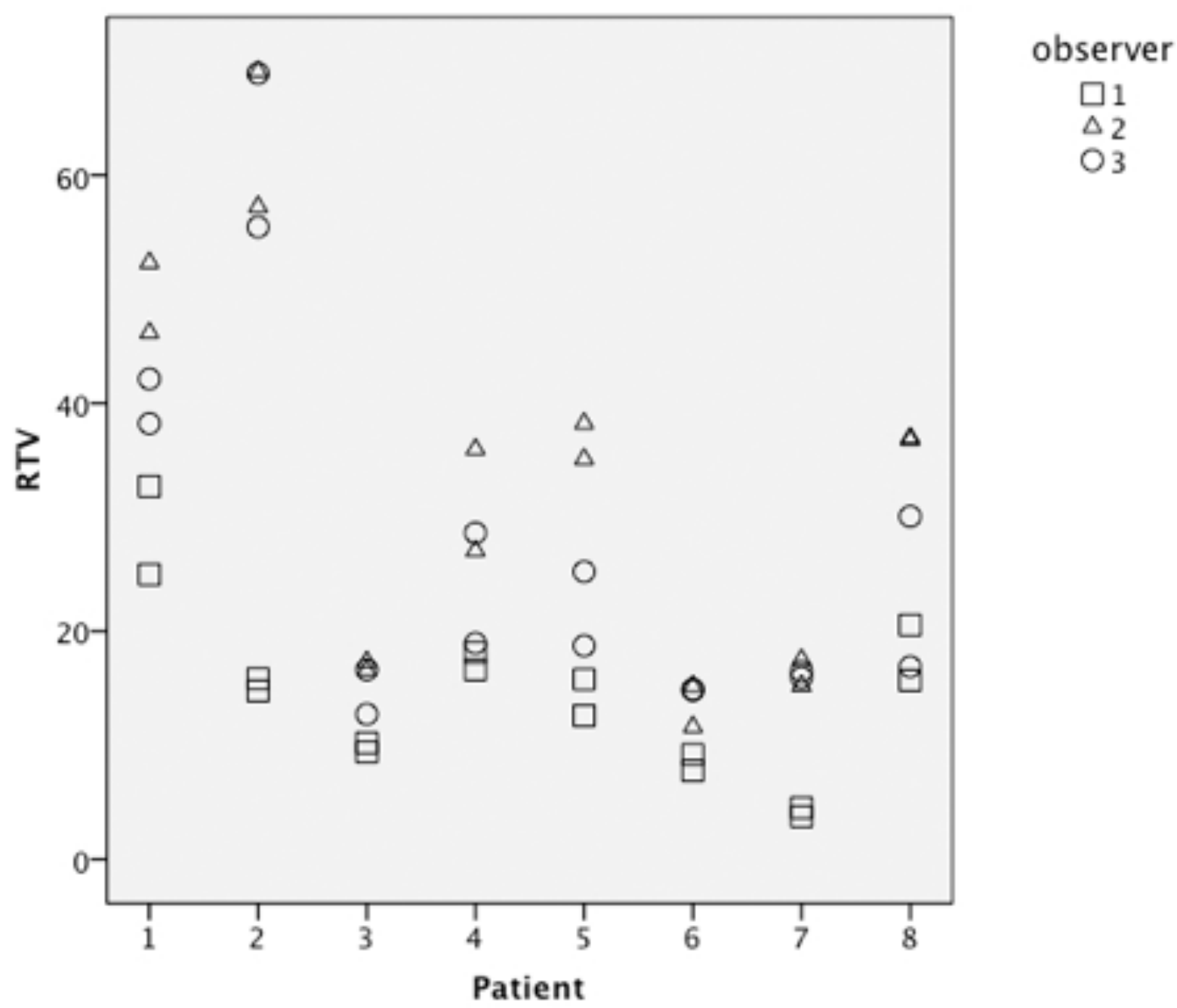

Figure 3.3: RTV measurements for each observer 


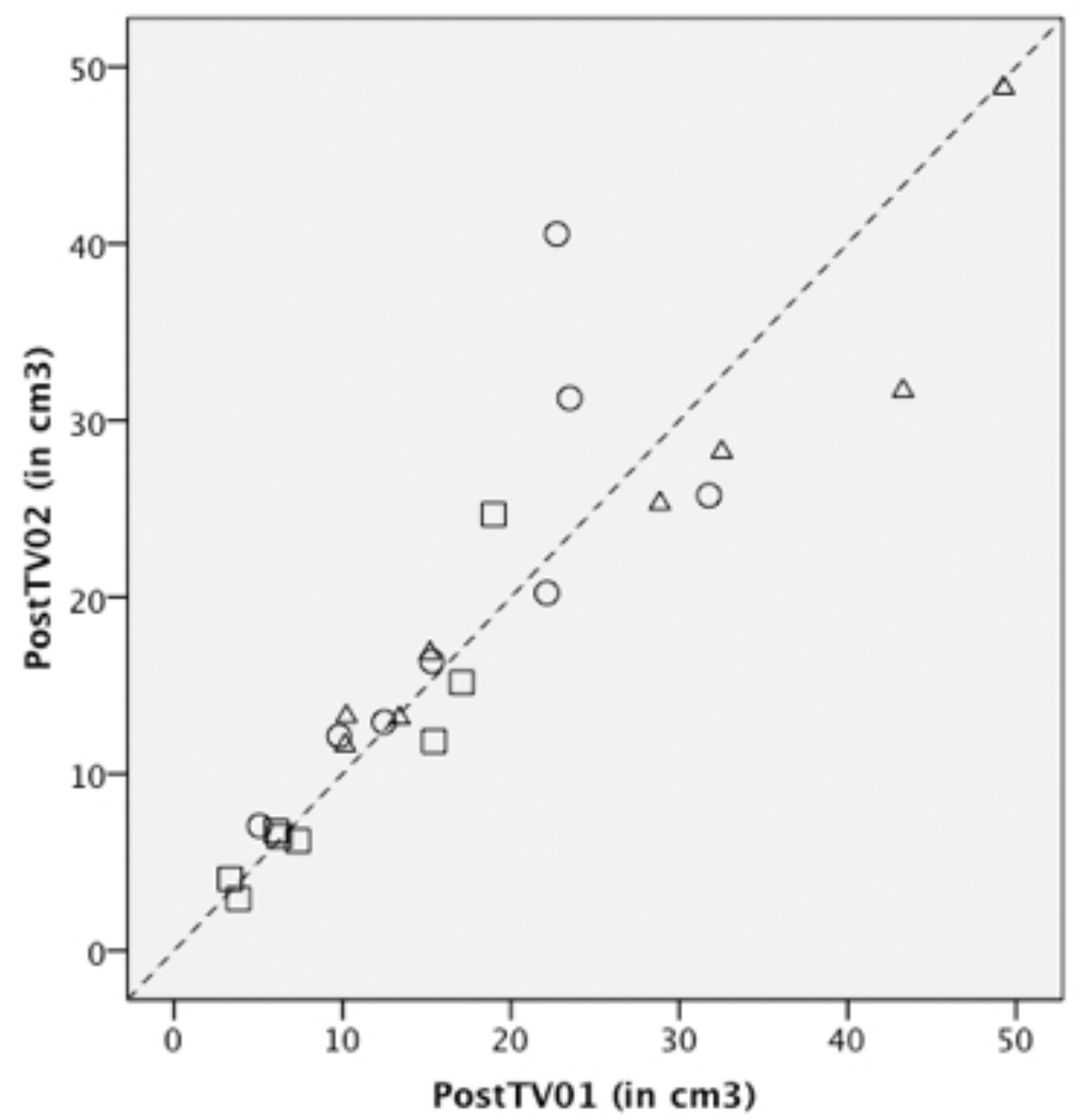

observer

$\square 1$

$\triangle 2$

$\mathrm{O} 3$

Figure 3.4: Comparison of PostTV in cm3 in first (PostTV01) and second (PostTV02) measurements.
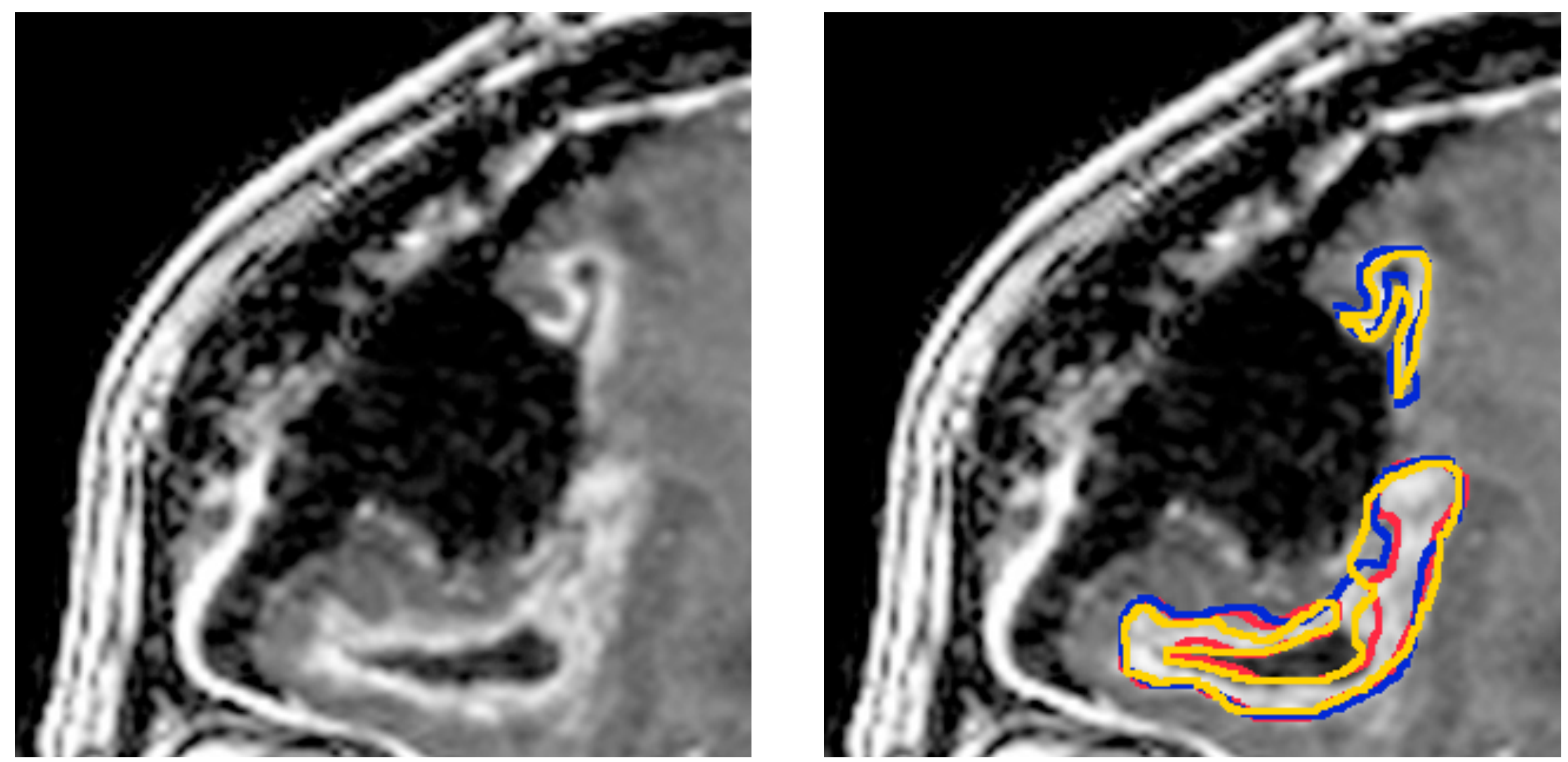

Figure 3.5: Postoperative illustration of case with low interobserver and even low intraobserver agreement without (5a) and with (5b) observers' segmentations. 


\section{DISCUSSION}

This study shows that volumetric assessment of glioblastoma resection provides consistent results for an individual observer, but variable results between different observers. This implies that absolute RTV values or RTV percentages relating EOTR to survival may be unreliable.

\section{Response assessment}

The MacDonald criteria are widely used for response assessment in glioma.[8] The approach of bidirectional measurements of the contrast-enhancing tumor area has its limitations.[1,16,4] For surgical response assessment, the often irregular shape of high grade gliomas is the most important one. Besides surgical manipulation, contrast enhancement can be influenced by a variety of circumstances: corticosteroids, radionecrosis, pseudoprogression (after temozolomide) and pseudoresponse (after antiangiogenesis agents).[1] These are important for postoperative follow-up. For presurgical tumor size assessment, unidirectional measurements could form a validated method to assess tumor volume.[17,3,13,18] But this approach works only for an approximately spheric tumor,[5] and is therefore not useful postoperatively.

Volumetry may be a better method for surgical response assessment, if measurements are based on the contrast-enhancing area. Sorensen showed an improved intraobserver and interobserver agreement for perimeter methods compared to diameter methods for tumor volume calculation.[15] No postoperative data were available in that study. Duong et al. described a volumetric approach to assess EOTR and used phantom scans to analyze the accuracy of the software and its users,[2] However, their protocol required digitizing CT film images with a slide scanner and recording them on a personal computer hard disk. Shi et al. improved this technique to enable direct input of MRI data, transferred by optical disks.[14] Both studies assessed intraobserver variability, which was estimated to be $1.7 \%$ and $1.8 \%$ respectively. These studies are only partially comparable to ours. None of these studies used volumescans, no ICCs were calculated and interobserver agreement was not mentioned.

\section{Observer agreement}

We calculated ICC for intraobserver and interobserver agreement of PreTV, PostTV and RTV on volumescans. We defined tumor volume as the contrast-enhancing mass with enclosed central necro- 
sis: this is consistent with other authors. [6,7,12] This definition does not correct for hyperintensities that are already visible on native T1-weighted MRI. Nimsky et al. used coregistration of all imaging data sets (e.g. T1-weighted, T2-weighted, fluid attenuated inversion recovery) for more accurate confirmation of the tumor contour.[9] This approach may result in a more accurate estimation of glioblastoma resection, but was not done in other studies and is not available on many computer systems. Besides, it is very labor-intensive. Our analysis took about 60 minutes per patient, which is likely to increase when using additional datasets for coregistration. Therefore this method is not usable in daily practice if not automated in the future.

The observers in our study compared their results to explain the low interobserver agreement for PostTV. Different interpretation of what to consider as postoperative tumor in an individual patient proved to be the main explanation for the low interobserver agreement. Areas that may be interpreted as either necrosis (representing residual tumor) or resection cavity formed the main difficulty. This was more prominent when PostTV exceeded $20 \mathrm{~cm}^{3}$ (Figure 3.4). Increased PostTV is associated with an increased number of slices: therefore the number of interpretation differences does increase as well. A typical case with low interobserver and even low intraobserver agreement (patient 4) is represented in Figure 3.5.

\section{Strengths and limitations}

The main strength of this study is that, to our opinion, it is the first study to address both intraobserver and interobserver agreement for glioblastoma volumetry. Measurements are performed on volumescans, which provide the best spatial resolution in all directions. The study involved observers from the field of neurosurgery and neuroradiology. The time interval between the first and second measurements prevented the observers from remembering their segmentation decisions of the previous time.

The main limitations of our study are the poor definition of postoperative tumor volume and the low number of patients. Defining glioblastoma as "the contrast-enhancing mass with enclosed necrosis" resulted in different interpretations when measured on contrast-enhanced T1-weighted MRI only.

Despite the limited number of patients, our results suggest that using manual segmentation to measure (especially large) PostTV is associated with low interobserver agreement. In these cases EOTR has to be assessed with great caution.

\section{Suggestions}

At least two aspects need to be addressed to establish a validated method for volumetric assessment of glioblastoma resection that is useful in daily practice. 
First, "postoperative tumor" needs to be defined more clearly. Issues that need to be clarified are how to deal with enclosed hypointensities on postoperative MRI and hyperintensities on native T1weighted MRI. Regarding hypointensities suspected to be necrosis, we consider "central necrosis" not to be a satisfactory description. On postoperative T1-weighted MRI discrimination between the resection cavity and residual necrosis can be difficult in a single plane (Figure 4). Only cyst-like parts that are surrounded by contrast-enhancing tissue should be considered as residual tumor with central necrosis. Otherwise we should consider these cyst-like parts to belong to the resection cavity. For that reason we prefer "enclosed necrosis" over "central necrosis", Regarding hyperintensities on native T1-weigthed MRI, they can relate to blood products in the resection cavity instead of residual tumor. When manually correcting for these hyperintensities, interobserver variability and time investment are issues of concern.

Second, computer-aided approaches should be implemented to facilitate segmentation of postoperative tumor. Software algorithms can be used to determine if cyst-like parts represent residual tumor or belong to a resection cavity: in the first case, they will be surrounded by contrast-enhancing tissue in all directions. Subtracting hyperintensities on native T1-weighted MRI from hyperintensities on contrast-enhanced T1-weighted MRI should reduce different interpretations of postoperative glioblastoma volume. Afterwards the software can quantify the remaining volume of interest. 


\section{CONCLUSION}

Volumetric assessment of glioblastoma resection seems to offer high intraobserver agreement, but low interobserver agreement. The results of this study suggest that using absolute residual tumor volume to relate EOTR with survival may be unreliable, especially for larger tumor volumes. More research is needed before this method can be used as a valid endpoint for clinical studies. Computer-assisted tumor volume calculation may increase interobserver agreement in the future. 


\section{REFERENCES}

1. den Bent van MJ, Vogelbaum MA, Wen PY, Macdonald DR, Chang SM. End point assessment in gliomas: novel treatments limit usefulness of classical Macdonald's Criteria. J Clin Oncol 2009; 27:2905-2908.

2. Duong DH, Rostomily RC, Haynor DR, Keles GE, Berger MS. Measurement of tumor resection volumes from computerized images. Technical note. J Neurosurg 1992; 77:151-154.

3. Galanis E, Buckner JC, Maurer MJ, Sykora R, Castillo R, Ballman KV, et al. Validation of neuroradiologic response assessment in gliomas: measurement by RECIST, two-dimensional, computerassisted tumor area, and computer-assisted tumor volume methods. Neuro-oncology 2006; 8:156165.

4. Henson JW, Ulmer S, Harris GJ. Brain tumor imaging in clinical trials. AJNR Am J Neuroradiol 2008; 29:419-424.

5. James K, Eisenhauer E, Christian M, Terenziani M, Vena D, Muldal A, et al. Measuring response in solid tumors: unidimensional versus bidimensional measurement. J Natl Cancer Inst 1999; 91:523528.

6. Keles GE, Anderson B, Berger MS. The effect of extent of resection on time to tumor progression and survival in patients with glioblastoma multiforme of the cerebral hemisphere. Surg Neurol 1999; 52:371-379.

7. Lacroix M, ea. A multivariate analysis of 416 patients with glioblastoma

multiforme: prognosis, extent of resection, and survival. J Neurosurg 2001; 95:190-198.

8. Macdonald DR, Cascino TL, Schold SC, Cairncross JG. Response criteria for phase II studies of supratentorial malignant glioma. J Clin Oncol 1990; 8:1277-1280.

9. Nimsky C, Fujita A, Ganslandt O, Keller Von B, Fahlbusch R. Volumetric Assessment of Glioma Removal by Intraoperative High-field Magnetic Resonance Imaging. Neurosurgery 2004;:358-371.

10. Pope WB, Sayre J, Perlina A, Villablanca JP, Mischel PS, Cloughesy TF. MR imaging correlates of survival in patients with high-grade gliomas. AJNR Am J Neuroradiol 2005; 26:2466-2474.

11. Sanai N, Berger MS. Glioma extent of resection and its impact on patient outcome. Neurosurgery 2008; 62:753-64; discussion 264-6. 
12. Schneider JP, Trantakis C, Rubach M, Schulz T, Dietrich J, Winkler D, et al. Intraoperative MRI to guide the resection of primary supratentorial glioblastoma multiforme-a quantitative radiological analysis. Neuroradiology 2005; 47:489-500.

13. Shah GD, Kesari S, Xu R, Batchelor TT, O'Neill AM, Hochberg FH, et al. Comparison of linear and volumetric criteria in assessing tumor response in adult high-grade gliomas. Neuro-oncology 2006; 8:38-46.

14. Shi WM, Wildrick DM, Sawaya R. Volumetric measurement of brain tumors from MR imaging. J Neurooncol 1998; 37:87-93.

15. Sorensen AG, Patel S, Harmath C, Bridges S, Synnott J, Sievers A, et al. Comparison of diameter and perimeter methods for tumor volume calculation. J Clin Oncol 2001; 19:551-557.

16. Sorensen AG, Batchelor TT, Wen PY, Zhang W-T, Jain RK. Response criteria for glioma. Nat Clin Pract Oncol 2008; 5:634-644.

17. Therasse P, Arbuck SG, Eisenhauer EA, Wanders J, Kaplan RS, Rubinstein L, et al. New guidelines to evaluate the response to treatment in solid tumors. European Organization for Research and Treatment of Cancer, National Cancer Institute of the United States, National Cancer Institute of Canada. J Natl Cancer Inst 2000; 92:205-216.

18. Warren KE, Patronas N, Aikin AA, Albert PS, Balis FM. Comparison of one-, two-, and threedimensional measurements of childhood brain tumors. J Natl Cancer Inst 2001; 93:1401-1405. 


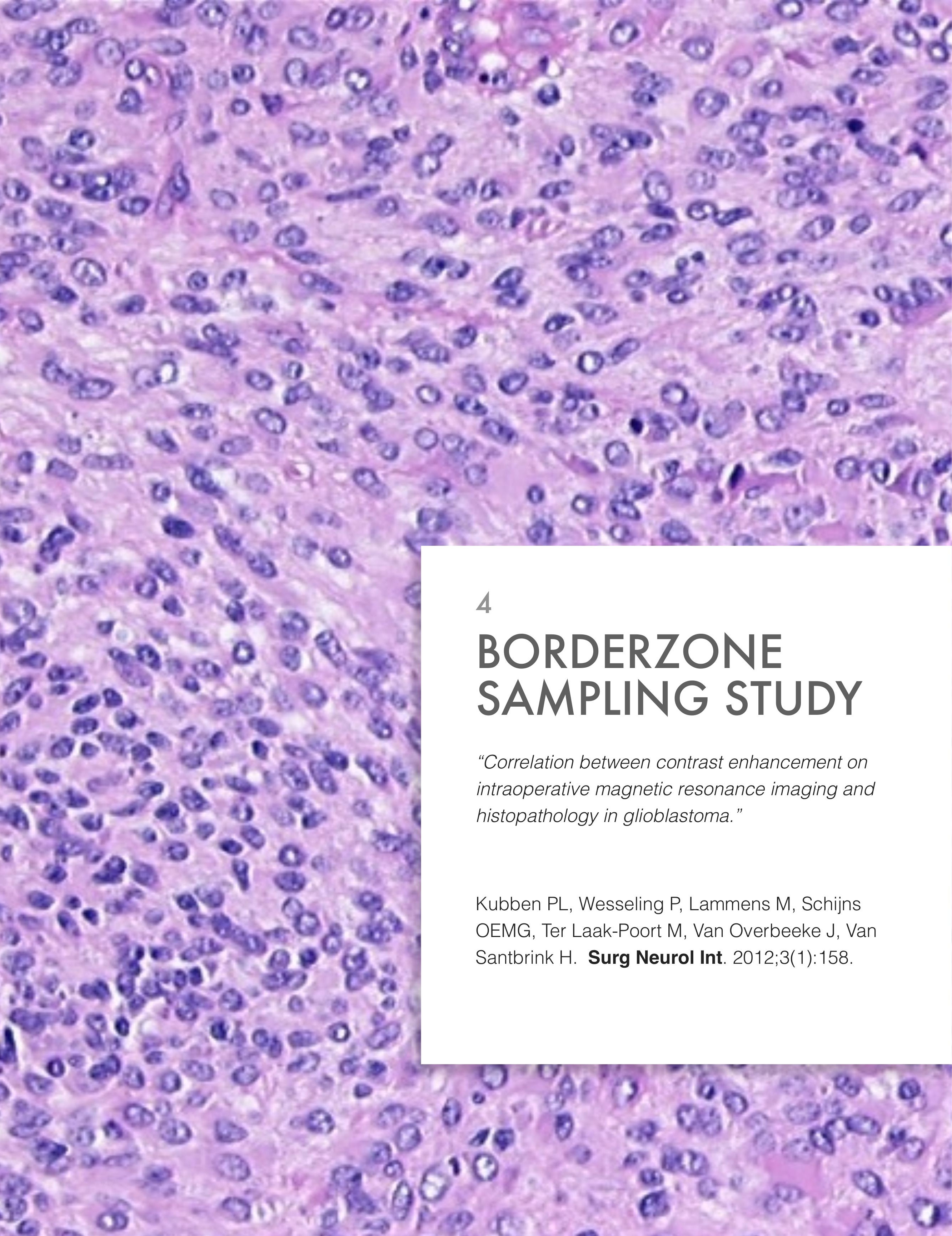




\section{INTRODUCTION}

Glioblastoma is a highly malignant brain tumor that often shows extensive infiltrative growth in the surrounding brain parenchyma. Standard treatment consists of surgery, radiotherapy and chemotherapy, leading to a median survival of 14.6 months.[30,29] Although the role of surgery is still under debate, mounting evidence suggests that increased extent of tumor resection (EOTR) is associated with prolonged survival.[24] Intraoperative MRI (iMRI) is a technique that can help to increase EOTR, comparable to the use of 5-aminolaevulinic acid (5-ALA).[27]

The added value of $\mathrm{MRI}$ in increasing EOTR for glioblastoma is based on visualizing remaining contrast enhancement on T1-weighted scans at the border of the resection cavity. This contrast enhancement is supposed to indicate residual tumor, which can be resected in the same procedure. In a few studies the additionally resected tissue was sent separately for histological analysis, leading to varying reports on tumor presence.[26,21,17] However, due to the infiltrative nature of a glioblastoma, tumor cells are often present outside the contrast enhancing area. [5,1] If contrast enhancement on T1-weighted iMRI is to be used as a marker for high grade glioma, then contrast enhancing tissue should exhibit more high grade tumor characteristics than non (contrast) enhancing tissue. Serial stereotactic biopsies have been performed on preoperative CT and MRI, demonstrating tumor cells outside the contrast enhancing area.[9] To our knowledge, such studies have not been performed systematically on $\mathrm{iMRI}$, in which contrast agent is administered after tumor resection (i.e. after possible iatrogenic damage to the blood brain barrier). Therefore, histologic results correlated to preoperative imaging might not correlate to iMRI.

This is the first study that systematically compares contrast enhancement on iMRI with histopathological characteristics in glioblastoma. The study objective is to determine to what extent contrast enhancement on T1-weighted iMRI can be used as a marker for presence of (high grade) glioma, and therefore as a valid indicator to assess EOTR. 


\section{METHODS}

The study protocol is registered at ClinicalTrials.gov under number NCT00780819 and has been approved by the institutional ethics research board.

\section{Patient selection}

For this prospective cohort study we recruited 10 patients with a supratentorial brain tumor suspect for a glioblastoma. We determined the number of patients to be included based on consensus in the study committee. Inclusion criteria were: indication for tumor resection, minimum age of 18 years, WHO Performance Scale 2 or better, ASA class 3 or better, understanding of the Dutch language, and informed consent. Exclusion criteria were: recurrent tumor, multiple tumor locations, prior radiotherapy on the skull, and prior chemotherapy.

\section{Study endpoints}

Primary endpoint of this study was the correlation between contrast enhancement at the border of the resection cavity on T1-weighted $\mathrm{MRI}$ and presence of high grade tumor according to the WHO classification.[16] Secondary endpoints of this study were: correlation between contrast enhancement at the border of the resection cavity on T1-weighted MRI and other histopathologial tissue characteristics, postoperative clinical condition, and survival.

\section{Surgical procedure}

All study participants were operated by a neurosurgeon (OS, MtLP or HvS) sufficiently experienced with the 0.15 Tesla iMRI system used in our hospital (PoleStar N2O with Stealth Station extension; Medtronic Navigation, Louisville, CO). After patient installation in the headclamp, a contrast enhanced preoperative (high-field strength) MRI was loaded for surgical planning and initial neuronavigation. Before incision a non enhanced iMRI scan was made as a baseline scan that intraoperatively acquired scans could be compared with.

During tumor resection, resected tissue was sent for standard histopathological analysis. As soon as the neurosurgeon considered the intended tumor resection to be complete, T1-weighted iMRI scans 
were acquired using the so-called "T1 7min 4mm"-protocol in axial orientation: first a non enhanced scan, then a contrast enhanced scan using gadopentetate dimeglumine (Magnevist; Bayer-Schering Pharma AG, Berlin, Germany). Contrast dose was $0.4 \mathrm{ml} / \mathrm{kg}(0.2 \mathrm{mmol} / \mathrm{kg})$ - a so-called "doubledose" - provided no renal failure was present. The contrast enhanced scan was made immediately after intravenous contrast administration.

After scanning neuronavigation was continued on the contrast enhanced iMRI scan, which was imported in the Stealth Station neuronavigation system. In all directions where gross total resection was intended, neuronavigation-guided biopsies were taken at the border of the resection cavity. A screen capture from the neuronavigation system was saved for each biopsy to relate contrast enhancement with histopathology. Each biopsy was sent separately for histopathological analysis, labeled with a number corresponding to the screen capture. After taking the biopsies, surgery was continued to resect any contrast enhancement in a direction where gross total resection was intended. Scanning was repeated if this goal was considered to be achieved, and additional biopsies were taken if safely possible. Contrast administration was only repeated if the previous iMRI scan was performed more than 2 hours ago, in a dose of $0.2 \mathrm{mml} / \mathrm{kg}(0.1 \mathrm{mmol} / \mathrm{kg})$ - a "single-dose" - provided no renal failure was present.

\section{Perioperative procedure}

Preoperative and postoperative MRI scans were made with the Intera 1.5 Tesla MRI system (Release 11.1; Philips, Best, The Netherlands). Preoperative neuronavigation scans were contrast-enhanced T1-weighted volume scans (isovoxel $1 \mathrm{~mm}$, gap thickness $0 \mathrm{~mm}$ ). Postoperative multiple sequences were acquired in a standardized fashion, including contrast enhanced T1-weighted sequences. Gadopentetate dimeglumine was used as a contrast agent in a dose of $0.2 \mathrm{ml} / \mathrm{kg}(0.1 \mathrm{mmol} / \mathrm{kg}) \mathrm{pro}-$ vided no renal failure was present.

All preoperative and postoperative scans were performed within 72 hours before and after surgery respectively.

WHO Performance Scale was measured the day before surgery, and one week after surgery.

\section{Determination of contrast enhancement}

The screen captures from the biopsy locations were independently reviewed by a neurosurgeon and a senior resident in neurosurgery (HVS and PK). Both have ample experience in interpreting PoleStar images. Contrast enhancement was scored according to a four-tier classification described by Ekinci et al, displayed in Table 4.1: none, thin linear, thick linear, and (suspected) residual tumor.[4] Screen captures that were scored differently by the reviewers were reviewed together to obtain consensus. 


\section{Table 4.1: Ekinci classification for scoring contrast enhancement}

\section{Description}

None

Thin linear

Thick linear

Suspected residual tumor

\section{Definition}

No visible contrast enhancement

Resembles normal dural enhancement $(<5 \mathrm{~mm}$ )

Thicker than typical dural enhancement ( $5-10 \mathrm{~mm}$ )

$>10 \mathrm{~mm}$ in any imaging plane

\section{Determination of histopathological characteristics}

The biopsy tissue samples were independently reviewed by two experienced neuropathologists (PW and $\mathrm{ML}$ ), blinded for corresponding contrast enhancement. Histopathological characteristics were scored for 10 parameters (most of these in a semiquantitative fashion): amount of tissue, quality of tissue, preexistent tissue, increased cellularity, tumor presence, mitoses, vascular changes, necrosis, inflammation, and $\mathrm{WHO}$ grade in the sample. To each individual biopsy specimen in which tumor was present a WHO grade was assigned according to the WHO 2007 classification of tumors of the central nervous system[15]: grade $\|=$ no mitotic activity, no necrosis and no florid microvascular proliferation found; grade III = mitotic activity present, but absence of necrosis and florid microvascular proliferation; grade IV: presence of necrosis and/or florid microvascular proliferation. The values for each parameter are displayed in Table 4.2.

\section{Table 4.2: Classification for histopathological characteristics}

\section{Parameter}

Preexistent tissue

WHO grade

Vascular changes

Necrosis

Mitoses

Increased cellularity

\section{Values}

white matter, gray matter, combination, indeterminate

no WHO grade: non-neoplastic (normal or reactive changes); WHO grade II: low grade diffuse astrocytoma; WHO grade III: anaplastic astrocytoma; WHO grade IV: glioblastoma

no apparent, vasodilatation, hypertrophic endothelium, florid microvascular proliferation

absent, indeterminate, focal, local, extensive

no, sparse, moderate, frequent

no apparent, limited, moderate, marked

The so-called "Tier 1 items" to be reported according to the "Biospecimen reporting for improved study quality" (BRISQ) recommendations are displayed in Table 4.3.[18] Tissue samples that were scored different by the neuropathologists were reviewed together to obtain consensus. 
Table 4.3: BRISQ Tier 1 items

Data element

Biospecimen type

Anatomic site

Disease status of patients

Clinical characteristics of patients

Vital state of patients

Clinical diagnosis of patients

Pathology diagnosis

Collection mechanism

Type of stabilization

Type of long-term preservation

Constitution of preservative

Storage temperature

Storage duration

Relocation temperature

Composition assessment \& selection

\section{Value}

Perifocal brain tumor parenchyma

Cerebrum

WHO Performance Scale $\leq 2$

Neurological deficit dependent on tumor location

Alive

Supratentorial intra-axial brain tumor, suspect for high grade glioma

Glioblastoma

Tumor forceps

Saline $0.9 \%$ solution

Formalin-fixed, paraffin embedded

$10 \%$ neutral-buffered formalin

Room temperature

6 - 18 months

Room temperature (after embedding in paraffin)

Scored as "adequate" regarding "amount of tissue" and "quality of tissue"

\section{Statistics}

Interobserver agreement for contrast enhancement, WHO classification and histopathological parameters were expressed as kappa-squared values, calculated with an in-house made application. Correlation between contrast enhancement and histopathological parameters was expressed as Kendall's tau with a one-tailed significance, calculated in PASW Statistics version 18.0.3 for Mac (IBM Corporation, Armonk, NY). Further analysis consisted of creating crosstables to calculate sensitivity, specificity, positive predictive value (PPV), negative predictive value (NPV), positive likelihood ratio $(\mathrm{LR}+)$ and negative likelihood ratio (LR-) for contrast enhancement in relation to WHO grade. Two definitions were used for presence of contrast enhancement: "thick linear + tumor-like" versus "thin linear + thick linear + tumor-like". Also, two definitions were used for presence of tumor: "grade III + grade IV" versus "grade II + grade III + grade IV". Calculations were performed with Microsoft Excel for Mac version 2011 (Microsoft, Redmond, WA), as well as the graphical representation of the interobserver agreement. 


\section{RESULTS}

\section{Patient characteristics}

Table 4.4 shows relevant characteristics of the 10 participants included in this study, including information on tumor location, and preoperative and postoperative WHO Performance Status (WPS). Patients were recruited between October 2008 and July 2009, and follow-up lasted until all patients died. Age varied between 46 and 71 years, with a mean of $59.7 \pm 9.0$ years. Six patients were male and four patients were female. The main tumor mass was located in the left versus right cerebral hemisphere in six and four patients, respectively, and the tumor was most frequently located in the frontal lobe $(n=4)$, followed by the temporal lobe $(n=3)$, parietal lobe $(n=2)$ and occipital lobe $(n=1)$.

\section{Table 4.4: Study demographics}

$\begin{array}{llllllll}\text { Code } & \text { Sex, Age (y) } & \begin{array}{l}\text { Tumor } \\ \text { location }\end{array} & \begin{array}{l}\text { WPS pre/ } \\ \text { post }\end{array} & \begin{array}{l}\text { Contrast } \\ \text { dose * }\end{array} & \begin{array}{l}\text { 2nd scan } \\ \text { delay }\end{array} & \text { NoS } & \text { NoATS } \\ \text { BZS01 } & \text { M, 51 } & \text { L frontal } & 0 / 0 & \text { double } & \text { N/A } & 5 & 5 \\ \text { BZS02 } & \text { M, 60 } & \text { R frontal } & 0 / 1 & \text { double } & 115 \text { min } & 5+1 & 4+1 \\ \text { BZS03 } & \text { M, 62 } & \text { L temporal } & 0 / 1 & \text { single } & \text { N/A } & 2 & 2 \\ \text { BZS04 } & \text { F, 69 } & \text { L frontal } & 1 / 1 & \text { double } & 90 \text { min } & 5+3 & 5+3 \\ \text { BZS05 } & \text { M, 46 } & \text { L temporal } & 1 / 1 & \text { double } & \text { N/A } & 3 & 2 \\ \text { BZS06 } & \text { F, 61 } & \text { L parietal } & 1 / 1 & \text { double } & \text { N/A } & 5 & 4 \\ \text { BZS07 } & \text { F, 47 } & \text { R temporal } & 2 / 2 & \text { double } & \text { N/A } & 3 & 3 \\ \text { BZS08 } & \text { M, 71 } & \text { R occipital } & 1 / 1 & \text { double } & \text { N/A } & 4 & 3 \\ \text { BZS09 } & F, 69 & \text { L frontal } & 1 / 1 & \text { double } & \text { N/A } & 4 & 3 \\ \text { BZS10 } & \text { M, 61 } & \text { R parietal } & 0 / 0 & \text { double } & \text { N/A } & 2 & 1\end{array}$

Abbreviations: $F=$ female,$L=$ left,$M=$ male, $\min =$ minutes,$N / A=$ not applicable, NoATS $=$ Number of Adequate Tumor Samples, NoS $=$ Number of Samples, post = postoperative, pre $=$ preoperative, $R=$ right, WPS $=$ WHO Performance Status, $y=$ years.

${ }^{*}$ A single dose of contrast is $0.1 \mathrm{mmol} / \mathrm{kg}$, a double dose is $0.2 \mathrm{mmol} / \mathrm{kg}$.

All patients but one were administered a double-dose of contrast agent, the remaining patient received a single-dose because of pre-existing renal dysfunction, which was however not a contraindication for gadolinium-based contrast agent. Standard histopathological examination of the 
resected tumor revealed glioblastoma as the clinical diagnosis for all patients. The total number of study biopsy samples of all patients was 42 . The number of biopsy samples per patient varied between 2 and 8 , with a mean of $4.2 \pm 1.9$ samples. In two patients biopsy samples were taken in two different phases during surgery. In those cases the delay between the first dose of contrast administration and the second iMR scan was 115 and 90 minutes, respectively, and according to our protocol no new dose of contrast agent was administered before the second iMR scan. Preoperative WPS varied between 0 and 2 , with a mean of $0.7 \pm 0.7$. Postoperative WPS varied between 0 and 2 , with a mean of $0.9 \pm 0.6$. Two patients (BZSO2 and BZS03) suffered from transient neurological deficit postoperatively, one due to a supplementory motor area (SMA) syndrome and another due to postoperative haemorrhage. Both patients recovered within a few days from WPS 3-4 to WPS 1. All patients received the standard treatment consisting of radiotherapy and chemotherapy postoperatively.[30,29] Postoperative survival varied between 40 and 721 days, with a mean of $350 \pm$ 215 days (median 372 days). Of note, the patient with the shortest survival (BZS05) opted for euthanasia. Postoperative survival is displayed as a Kaplan-Meier curve in Figure 4.1.

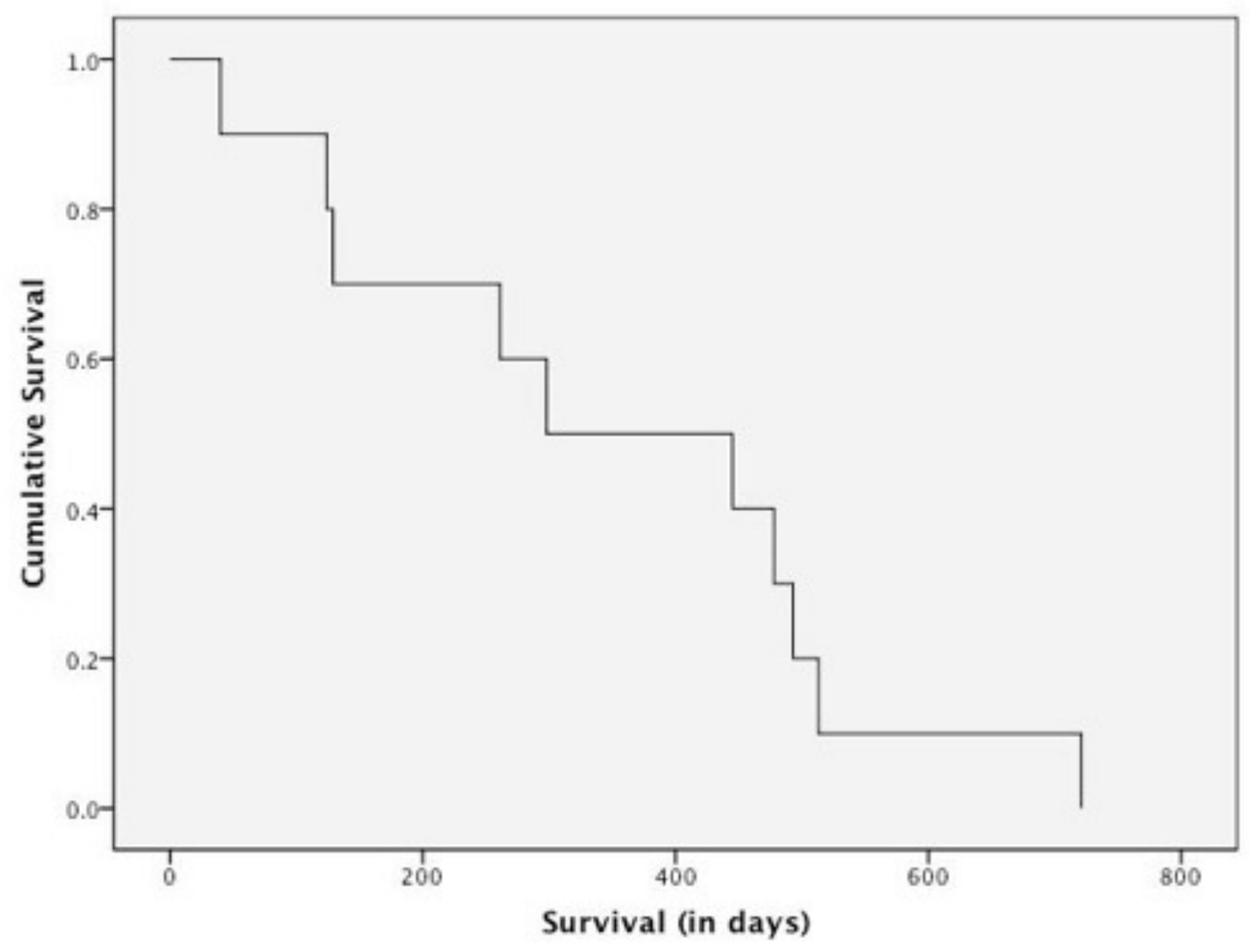

Figure 4.1: Kaplan-Meier curve displaying postoperative survival 


\section{Interobserver agreement}

A total of 42 samples were available for further analysis, 39 of these were scored as "adequate" both

Table 4.5a: Interobserver comparison for "contrast enhancement"

$\begin{array}{lllll} & \text { None } & \text { Thin linear } & \text { Thick linear } & \text { Resi } \\ \text { None } & 20 & 1 & 0 & 0 \\ \text { Thin linear } & 2 & 5 & 2 & 4 \\ \text { Thick linear } & 0 & 1 & 2 & 3 \\ \text { Residual tumor } & 0 & 0 & 0 & 2\end{array}$

on "amount of tissue" and "quality of tissue". Table 4.5 shows the results for both observers for contrast enhancement and tissue characteristics for these 39 samples.

Table 4.5b: Interobserver comparison for "WHO grade"

Normal / NT RC Grade II Grade III Grade IV

$\begin{array}{llllll}\text { Normal / NT } & 6 & 1 & 0 & 0 & 0 \\ \text { RC } & 1 & 0 & 0 & 0 & 0 \\ \text { Grade II } & 0 & 1 & 4 & 0 & 0 \\ \text { Grade III } & 0 & 0 & 3 & 0 & 4 \\ \text { Grade IV } & 0 & 0 & 2 & 2 & 12\end{array}$

Abbreviations: $N T=$ No Tumor,$R C=$ Reactive Changes

Table 4.5c: Interobserver comparison for "preexistent tissue"

$\begin{array}{lllll} & \text { Grey + white } & \text { White } & \text { Grey } & \text { Indeterminate } \\ \text { Grey + white } & 9 & 2 & 1 & 1 \\ \text { White } & 3 & 4 & 0 & 2 \\ \text { Grey } & 5 & 1 & 0 & 1 \\ \text { Indeterminate } & 0 & 1 & 0 & 12\end{array}$

Table 4.5d: Interobserver comparison for "increased cellularity"

$\begin{array}{llllll} & \text { Extreme } & \text { Marked } & \text { Moderate } & \text { Limited } & \text { No apparent } \\ \text { Extreme } & 0 & 2 & 0 & 1 & 0 \\ \text { Marked } & 0 & 6 & 9 & 1 & 0\end{array}$


Table 4.5e: Interobserver comparison for "vascular changes"

$\begin{array}{lllll} & \text { No apparent } & \text { Vasodilatation } & \text { + HT } & \text { + Florid MVP } \\ \text { No apparent } & 10 & 1 & 0 & 0 \\ \text { Vasodilatation } & 7 & 2 & 1 & 0 \\ \text { + HT } & 2 & 1 & 3 & 4 \\ \text { + Florid MVP } & 0 & 0 & 1 & 7\end{array}$

Abbreviations: $H T$ = hypertrophic endothelium, MVP = microvascular proliferation

Table 4.5f: Interobserver comparison for "necrosis"

$\begin{array}{llllll} & \text { Extensive } & \text { Local } & \text { Focal } & \text { Indeterminate } & \text { Absent } \\ \text { Extensive } & 4 & 0 & 0 & 0 & 1 \\ \text { Local } & 2 & 1 & 0 & 0 & 0 \\ \text { Focal } & 0 & 1 & 0 & 0 & 1 \\ \text { Indeterminate } & 0 & 0 & 0 & 2 & 3 \\ \text { Absent } & 0 & 0 & 3 & 1 & 23\end{array}$

Table 4.5g: Interobserver comparison for "mitoses"

$\begin{array}{lllll} & \text { Frequent } & \text { Moderate } & \text { Sparse } & \text { No } \\ \text { Frequent } & 1 & 2 & 3 & 0 \\ \text { Moderate } & 1 & 3 & 0 & 0 \\ \text { Sparse } & 0 & 0 & 4 & 4 \\ \text { No } & 0 & 0 & 4 & 20\end{array}$

Interobserver agreement is calculated for each parameter and expressed as kappa-squared with 95\% confidence intervals in Figure 4.2. For all biopsies, tumor parameters that were scored differently by both observers were scored again, now by both observers simultaneously. This consensus-based final value was chosen for further analysis. 


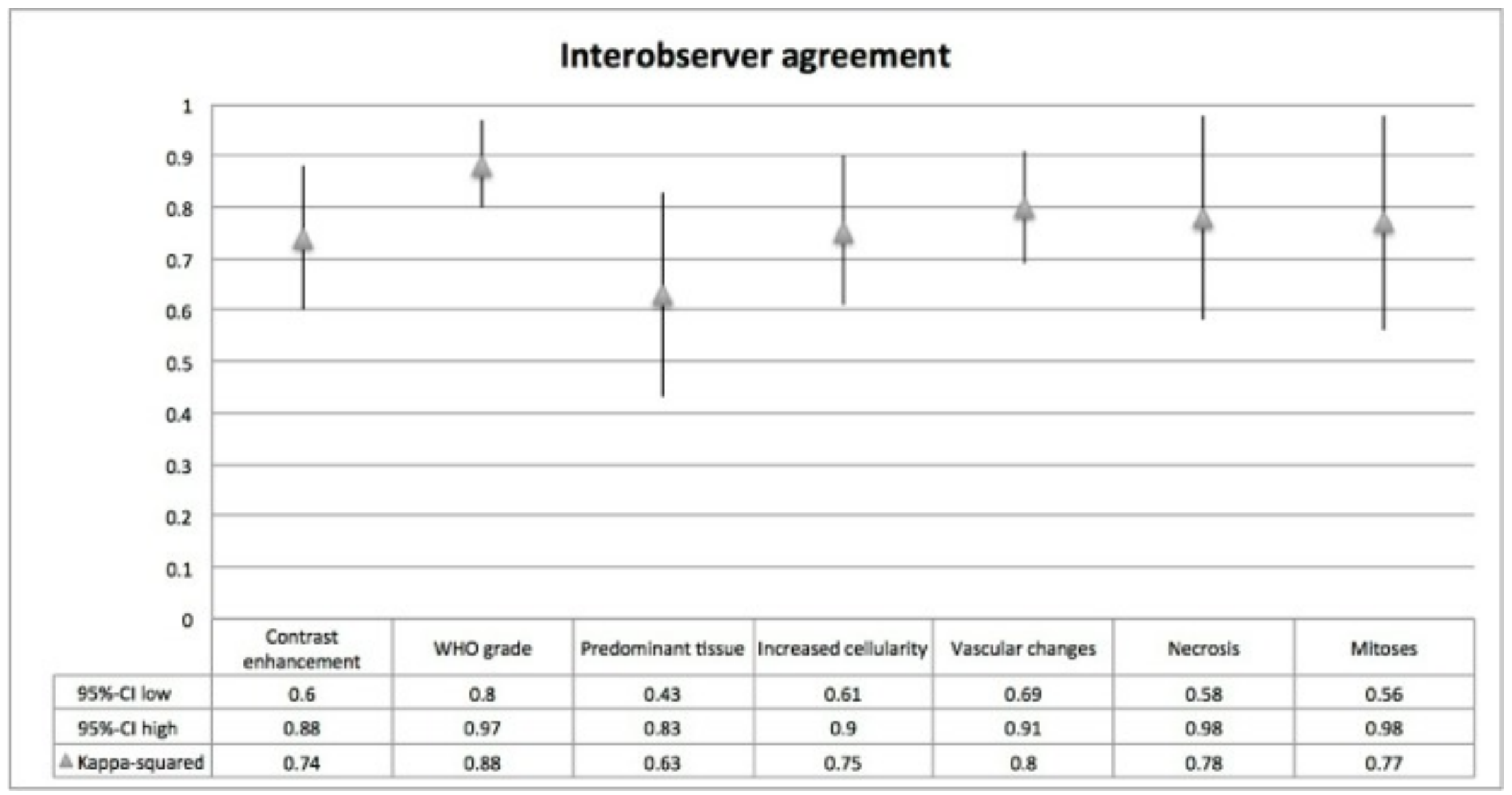

Figure 4.2: Interobserver agreement for each tumor parameter expressed in kappa-squared $(\mathrm{Cl}=$ confidence interval $)$

\section{Correlation between contrast enhancement and tumor}

Of the 39 adequate biopsy samples, 3 had an uncertain diagnosis regarding WHO grade. Correlations between contrast enhancement and tumor were calculated using the remaining 36 samples and displayed in Table 4.6. Four tumor parameters demonstrated a significant correlation with contrast enhancement: WHO grade, vascular changes, necrosis and increased cellularity. In particular the first three demonstrated highly significant but only moderately strong correlation, with Kendall's tau values around 0.50. The parameter "tumor presence" was found to have no additional value over the information obtained by combining grade II, III and IV lesions in the parameter "WHO grade". Furthermore, substantial interobserver variation for the parameter "inflammation" prevented meaningful analysis of this parameter. Therefore, the parameters "tumor presence" and "inflammation" are not further incorporated in the tables and results. 
Table 4.6: Correlation coefficients for "contrast enhancement" related to other tumor parameters

$\begin{array}{llll}\text { Tumor parameter } & \text { Kendall's tau } & \text { Significance * } & \text { NoS } \\ \text { WHO grade } & 0.50 & <0.01 & 36 \\ \text { Vascular changes } & 0.53 & <0.01 & 38 \\ \text { Necrosis } & 0.49 & <0.01 & 39 \\ \text { Mitoses } & 0.09 & 0.27 & 39 \\ \text { Increased cellularity } & 0.26 & 0.03 & 39\end{array}$

Abbreviation: NoS = Number of Samples (available for statistical analysis per tumor parameter)

* The 1-tailed significance is expressed in a p-value.

\section{Subgroup analysis}

To gain more insight in the type of correlation, crosstables are created to relate the values for contrast enhancement with the respective values for each tumor parameter. The results are presented in Table 4.7, and used to calculate sensitivity, specificity, PPV, NPV, LR+ and LR-.

Table 4.7a: Crosstable for "contrast enhancement" with "WHO grade"

\section{Normal / NT Grade II Grade III Grade IV}

No enhancement 6

Thin linear $\quad 2$

Thick linear

Suspected tumor
4

1

0

0
3

2

1

0
4

3

5

5

Abbreviations: NT $=$ No Tumor

Table 4.7b: Crosstable for "contrast enhancement" with "increased cellularity"

No

\section{No apparent Limited} 5

4

\section{Moderate}

6

Marked

enhancement

Thin linear 2

Thick linear

Suspected

tumor 
Table 4.7c: Crosstable for "contrast enhancement" with "vascular changes"

$\begin{array}{lllll} & \text { No apparent } & \text { Vasodilatation } & +\mathrm{HT} & \text { + Florid MVP } \\ \text { No enhancement } & 11 & 2 & 4 & 2 \\ & & & & 1 \\ \text { Thin linear } & 2 & 3 & 2 & 3 \\ \text { Thick linear } & 0 & 2 & 1 & 5\end{array}$

Abbreviations: $H T=$ hypertrophic endothelium, $M V P=$ microvascular proliferation

Table 4.7d: Crosstable for "contrast enhancement" with "necrosis"

Absent Indeterminate Focal Local Extensive

No enhancement 17

$0 \quad 2$

0

Thin linear

\section{4}

1

1

$0 \quad 2$

Thick linear

1

1

0

2

3

Suspected tumor 2

0

2

0

1

Table 4.8 shows these values for the correlation between "contrast enhancement" and "WHO grade" using two definitions for each parameter (see also Materials and Methods). If "contrast enhancement" is defined as "thick linear" plus "tumor-like" then the PPV is 1 and the LR+ goes to infinity, regardless of tumor definition (only high grade components versus low grade components as well). Sensitivity is 0.48 if only high grade components are included, and 0.39 if low grade components are included as well. If "contrast enhancement" is defined including "thin linear" enhancement, then specificity falls to circa 0.75 and sensitivity rises to 0.70 (for only high grade components) or 0.61 (including low grade components).

Figure 4.3 contains a web diagram illustrating the sensitivity and specificity of contrast enhancement (using two definitions) for all significantly correlated tumor parameters.

Sensitivity, NPV and LR- all vary around 0.50. This means that half of the histologically confirmed "tumor samples" show contrast enhancement, and half do not. Also, half of the contrast enhancing samples are classified as "tumor", and half are not. 
Table 4.8: Subgroup analysis correlating "contrast enhancement" and "WHO grade" using two definitions per parameter

$\begin{array}{lllll}\begin{array}{lll}\text { Contrast definition } \\ \text { thick linear }+\end{array} & \begin{array}{l}\text { thick linear }+ \\ \text { tumor-like }\end{array} & \begin{array}{l}\text { thin linear + thick } \\ \text { linear + tumor-like }\end{array} & \begin{array}{l}\text { thin linear + thick } \\ \text { linear + tumor-like }\end{array} \\ \begin{array}{llll}\text { Tumor definition * } \\ \text { III + IV }\end{array} & \text { II + III + IV } & \text { III + IV } & \text { II + III + IV } \\ \text { Sensitivity } & 0.48 & 0.39 & 0.70 & 0.61 \\ \text { Specificity } & 1.00 & 1.00 & 0.77 & 0.75 \\ \text { PPV } & 1.00 & 1.00 & 0.84 & 0.89 \\ \text { NPV } & 0.52 & 0.32 & 0.59 & 0.35 \\ \text { LR+ } & \infty & \infty & 3.01 & 2.43 \\ \text { LR- } & 0.52 & 0.61 & 0.40 & 0.52\end{array}$

Abbreviations: $L R-=$ Negative Likelihood Ratio, $L R+=$ Positive Likelihood Ratio, $N P V=$ Negative Predictive Value, $P P V=$ Positive Predictive Value, thick linear $=$ Thick Linear enhancement, thin linear $=$ Thin Linear enhancement, tumor-like $=$ Suspected residual tumor enhancement

* Tumor definition is expressed in "WHO grade" as explained in the Methods section 


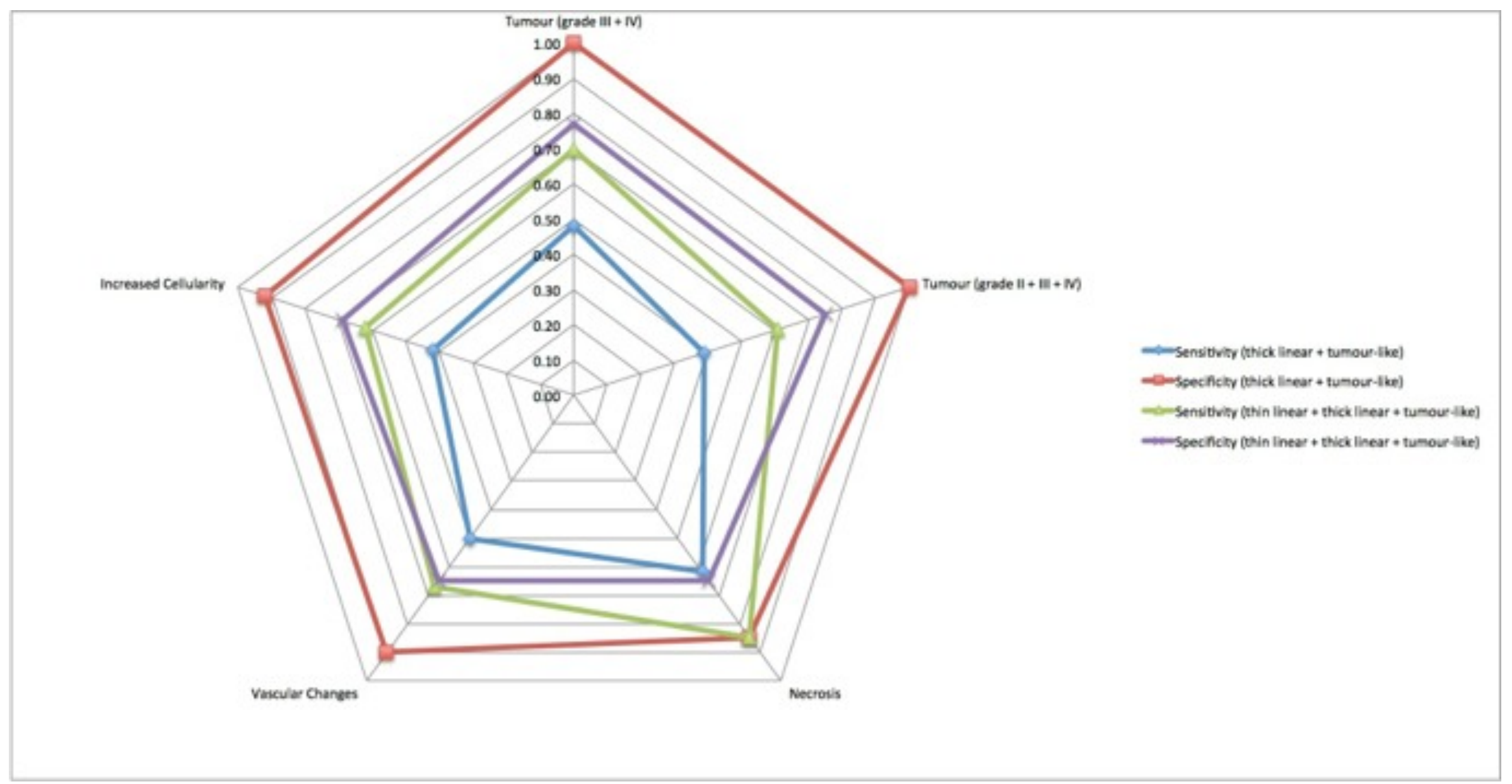

Figure 4.3: Web diagram demonstrating sensitivity and specificity of contrast enhancement (using two definitions) for all significantly correlated tumor parameters. 


\section{DISCUSSION}

The goal of a "gross total resection", or "complete resection of enhancing tumor" (CRET) [31] of a glioblastoma is to resect the contrast enhancing part as visualized on T1-weighted MRI. However, tumor cells are known to be present outside this contrast enhancing area,[5,1] and recent studies comparing contrast enhancement on T1-weighted MRI with diffusion weighted MRI and Positron Emission Tomography have demonstrated a considerable non-overlap between tumor delineation using these different techniques.[7,22] Our study compares contrast enhancement at the border of the resection cavity with histopathological tumor characteristics to determine to what extent contrast enhancement correlates with tumor.

The classification we used for contrast enhancement is derived from Ekinci et al.[4] They describe that thin linear "dural like" enhancement leads to tumor regrowth in only 1 out of 16 cases, whereas thick linear enhancement leads to tumor regrowth in all cases, in particular when nodular (tumor-like) components are present. The study by Ekinci studied postoperative 1.5 Tesla MRI using 0.1-0.2 $\mathrm{mmol} / \mathrm{kg}$ gadolinium-DTPA. Intraoperative contrast enhancement may differ due to iatrogenic manipulation and direct damage to the blood-brain barrier. Therefore we used two definitions for "contrast enhancement" in our study, both with and without thin linear enhancement.

Four histological parameters are significantly correlated with contrast enhancement at the border of the resection cavity: WHO grade, vascular changes, necrosis and increased cellularity. Of note, these histological features are interrelated. For instance, diffusely increased cellularity in a brain biopsy sample is an important indicator for the presence of a diffuse glioma, and the presence of necrosis and/or florid microvascular proliferation are the histological hallmarks of high malignancy grade in a diffuse glioma. Furthermore, the correlation itself is relatively weak, with Kendall's tau values of 0.49 0.53 for WHO grade, vascular changes and necrosis, and a value of 0.26 for increased cellularity. As the Kendall's tau is a non-parametric test that describes correlation but provides no detailed information on the kind of correlation, we calculated sensitivity and specificity for the relation between contrast enhancement and tumor presence, using two definitions for each. Our results are consistent with Ekinci et al for thick linear + tumor-like enhancement: specificity is 1, regardless whether tumor definition includes what we defined as "WHO grade II". Importantly, all patients in our study had a histologically proven glioblastoma. With the histological designation WHO grade II to biopsy samples of these patients we refer to samples in which the tumor lacked histological features of high grade malignancy in that particular (small) specimen. Of note, glioblastomas often show areas (e.g. in the diffuse infiltrative, peripheral parts) in which such histological features of high grade malignancy are lacking, but this does not necessarily mean that the glioblastoma originated from a less malignant pre- 
cursor lesion. Likewise, PPV and LR+ are maximal for thick linear + tumor-like enhancement regardless of tumor definition. Sensitivity is rather low: 0.48 when including only high grade tumor components, and 0.39 when including grade II components as well. Comparable conclusions can be drawn for NPV and LR-. If we expand our definition of contrast enhancement to include thin linear enhancing tissue, specificity falls to circa 0.75 regardless of tumor definition, PPV varies around $0.84-0.89$ and $L R+$ varies around $2.4-3.0$. Sensitivity rises to 0.70 for only high grade components, and 0.61 if grade II components are included. NPV and LR- also improve slightly.

Translating these numbers into practical conclusions, one can say that presence of evident contrast enhancement (thick linear + tumor-like) always refers to presence of tumor, regardless of whether histologically less malignant components are included. This is an interesting finding because "iatrogenic damage" to the blood-brain barrier is thought to cause false-positive intraoperative contrast enhancement. Our results demonstrate that this is not the case for thick linear enhancement, but it might be an explanation for the lower specificity when thin linear enhancement is included. Note that we refrained from contrast administration before incision to prevent residual contrast enhancement after tumor resection, which possibly can cause contrast enhancement in non-tumorous tissue.[6]

Absence of tumor is always correlated with absence of thick linear enhancement and tumor-like enhancement. Unfortunately, our study shows that absence of contrast enhancement is not useful for predicting absence of tumor. In our study $41-68 \%$ of the biopsy samples showed tumor despite absence of contrast enhancement, depending on definition of enhancement (thin linear + thick linear + tumor-like versus thick linear + tumor-like).

\section{Strengths and limitations}

To the best of our knowledge this is the first report with a prospective systematic comparison of intraoperative contrast enhancement and histopathological tumor characteristics, with comparison of biopsies from contrast enhancing and non enhancing tissue as a particular added value. This is in contrast with previously published work.[17,21,26] Another strength is that both neuropathologists, evaluating the histological parameters in the biopsies, were blinded for the pattern of contrast enhancement.

As far as we know, no validated scoring systems exist for contrast enhancement or for assessment of the histopathological characteristics of glial tumors as assessed in the present study. The scale we used for grading contrast enhancement has been published in an evaluation of tumor regrowth on postoperative MRI, and the scale we used for grading histopathological characteristics has been developed by two experienced neuropathologists (PW, ML). To increase reliability we assessed interobserver agreement for all measurements, and found this to be satisfactory except for the 
parameter "inflammatory changes". Consensus-based outcomes were used for further analysis, thereby decreasing subjectivity and variation in measurements.

The sample number of 10 patients may be relatively low, but the number of biopsies that was adequate for further analysis $(n=39)$ was satisfactory. The number of biopsy samples per patient varied because (as also described in the inclusion criteria) the neurosurgeon only took biopsies in those directions where it was considered to be safely possible.

Magnetic field strength is related to spatial resolution of the MR images and capacity of obtaining other imaging modalities (e.g. diffusion weighted imaging, MR spectroscopy). A limitation of this study is that our results can not automatically be transferred to high-field strength iMRI. However, we do not expect that using a high-field strength iMRI would result in a substantially different outcome as this would only increase spatial resolution. Of course, the use of additional imaging modalities could be of added value.

We used gadopentetate dimeglumine for this study, and gadolinium-based contrast agents are commonly used for (intraoperative ) MRI. An interesting alternative for neurosurgeons might be the use of so-called "ultrasmall particles of iron oxide" (USPIO) based agents, which have been tested on iMRI as well.[19,20,8] These might be less susceptible for iatrogenic damage of the blood-brain barrier, and could offer better correlations between thin linear contrast enhancement and tumor. Of note, in case of thick linear and tumor-like enhancement we found no indications for imaging artefacts (in particular false-positive contrast enhancement) related to damage of the blood-brain barrier. Specificity for high grade tumor in this pattern of contrast enhancement equals 1.

Our study is limited to assessment of remaining tumor using iMRI. A recent study investigated the use of 5-ALA as a marker for representative stereotactic biopsy samples in several types of tumor, and found better values compared to our study for specificity (1.00) and sensitivity (0.69) in case of strong 5-ALA fluorescence [33]. Another study used 5-ALA to differentiate between necrosis, (fluorescent) "tumor cells" and (non-fluorescent) "margin cells". They found that margin cells do not possess a 'stem-cell molecular signature' but retain tumor-initiating ability in vivo.[23] This finding is important, as it contradicts the belief that especially these margin cells are highly tumorigenic. To what extent 5-ALA fluorescence correlates with contrast enhancement on iMRI (and therefore -indirectly- with tumorigenicity of cells at the resection cavity, is currently being investigated (Senft et al, personal communication). The consequences of these findings on surgical strategy regarding EOTR remain to be seen.

\section{Implications for the future}

Contrast enhancement on low-field strength $\mathrm{MRI}$ at the border of the glioblastoma resection cavity has a high specificity but low sensitivity for high grade tumor. Absence of contrast enhancement is 
unreliable to assess absence of tumor, and from that perspective the rationale for CRET becomes debatable. Especially in glioma surgery complication avoidance is of critical importance. Increasing sensitivity of tumor detection to increase EOTR may be undesirable if a correponding lower specificity is associated with a higher incidence of (and/or more severe) postoperative neurological deficit. Furthermore, the definition of "tumor" is being discussed to include more than the contrast enhancing part, $[32,31]$ and this may change the philosophy about maximizing tumor resection. There is class 1 evidence that iMRI offers increased EOTR compared to a population of high grade glioma patients that were operated with or without conventional neuronavigation.[27] In a post-hoc exploratory analysis Senft et al. found no difference between both treatment arms in the control group, which is consistent with Willems et al. $[34,27]$ Based on other literature there is, at best, class 2 evidence that iMRI-guided surgery is more effective than conventional neuronavigation-guided surgery in increasing EOTR, enhancing quality of life, or prolonging survival after glioblastoma resection.[10]

Recently, the concept of 'functional neuro-oncology' was introduced by Duffau et al in low grade gliomas as a method to achieve optimal surgical resection guided by functional rather than by oncological-anatomical boundaries.[2,3] This approach does not suffer from imaging-related limitations. If increased EOTR is associated with prolonged survival, the "functional neurooncology" approach might also be an alternative in high grade glioma surgery to determine resection borders compared to an imaging-based approach. 


\section{CONCLUSION}

Our present study on glioblastomas shows that evident contrast enhancement (thick linear + tumorlike) as detected on iMRI always reflects presence of high grade tumor and may thus be used as a parameter to increase EOTR. Furthermore, absence of tumor is always correlated with absence of such contrast enhancement. Unfortunately absence of contrast enhancement and presence of thin linear enhancement on iMRI is not useful for predicting absence of tumor. Obviously, diffuse gliomas including glioblastomas are neoplasms that cannot be cured surgically. An (arbitrary) minimally required resection threshold to improve survival, like the widely cited $98 \%$ as described by Lacroix et al[13] is debatable, and a valid method to measure this threshold still has to be established. $[31,11,25,12,28,14]$ The use of 5-ALA or a "functional neurooncology" approach may be

interesting alternatives for high grade glioma surgery using gadolinium-based contrast agents to increase EOTR safely. 


\section{REFERENCES}

1. Claes A, Idema AJ, Wesseling P. Diffuse glioma growth: a guerilla war. Acta Neuropathol 2007; 114:443-458.

2. Duffau H. Surgery of low-grade gliomas: towards a 'functional neurooncology'. Curr Opin Oncol 2009; 21:543-549.

3. Duffau $\mathrm{H}$. The challenge to remove diffuse low-grade gliomas while preserving brain functions. Acta Neurochirurgica 2012; 54:569-574.

4. Ekinci G, Akpinar IN, Baltacioğlu F, Erzen C, Kiliç T, Elmaci I, et al. Early-postoperative magnetic resonance imaging in glial tumors: prediction of tumor regrowth and recurrence. Eur J Radiol 2003; 45:99-107.

5. Fan G, Sun B, Wu Z, Guo Q, Guo Y. In vivo single-voxel proton MR spectroscopy in the differentiation of high-grade gliomas and solitary metastases. Clinical radiology 2004; 59:77-85.

6. Hall WA, Truwit CL. Intraoperative MR-guided neurosurgery. J Magn Reson Imaging 2008; 27:368375.

7. Holodny AI, Makeyev S, Beattie BJ, Riad S, Blasberg RG. Apparent diffusion coefficient of glial neoplasms: correlation with fluorodeoxyglucose-positron-emission tomography and gadoliniumenhanced MR imaging. AJNR Am J Neuroradiol 2010; 31:1042-1048.

8. Hunt MA, Bago AA, Neuwelt EA. Single-Dose Contrast Agent for Intraoperative MR Imaging of Intrinsic Brain Tumors by Using Ferumoxtran-10. AJNR 2005; 26:1084-1088.

9. Kelly PJ, Daumas-Duport C, Kispert DB, Kall BA, Scheithauer BW, Illig JJ. Imaging-based stereotaxic serial biopsies in untreated intracranial glial neoplasms. J Neurosurg 1987; 66:865-874.

10. Kubben PL, Meulen Ter KJ, Schijns OE, Laak-Poort Ter MP, van Overbeeke JJ, Santbrink HV. Intraoperative MRI-guided resection of glioblastoma multiforme: a systematic review. The Lancet Oncology $2011 ; 12: 1062-1070$.

11. Kubben PL, Postma AA, Kessels AGH, van Overbeeke JJ, van Santbrink H. Intraobserver and interobserver agreement in volumetric assessment of glioblastoma multiforme resection. Neurosurgery 2010; 67:1329-1334. 
12. Kubben P, van Santbrink H. Glioblastoma resection. J Neurosurg 2012; 116:1163-4- author reply $1167-8$.

13. Lacroix $\mathrm{M}$, ea. A multivariate analysis of 416 patients with glioblastoma

multiforme: prognosis, extent of resection, and survival. J Neurosurg 2001; 95:190-198.

14. Lang FF, Sawaya R, Suki D, Mccutcheon IE, Hess KR. Letter to the editor: Glioblastoma resection. J Neurosurg 2012;

15. Louis DN, Ohgaki H. WHO classification of tumours of the central nervous system. WHO, 2007

16. Louis DN, Ohgaki H, Wiestler OD, Cavenee WK, Burger PC, Jouvet A, et al. The 2007 WHO classification of tumours of the central nervous system. Acta Neuropathol 2007; 114:97-109.

17. Martin AJ, Hall WA, Liu H, Pozza CH, Michel E, Casey SO, et al. Brain tumor resection: intraoperative monitoring with high-field-strength MR imaging-initial results. Radiology 2000; 215:221-228.

18. Moore HM, Kelly AB, Jewell SD, McShane LM, Clark DP, Greenspan R, et al. Biospecimen reporting for improved study quality (BRISQ). Cancer Cytopathol 2011; 119:92-101.

19. Neuwelt EA, Várallyay P, Bagó AG, Muldoon LL, Nesbit G, Nixon R. Imaging of iron oxide nanoparticles by MR and light microscopy in patients with malignant brain tumours. Neuropathol Appl Neurobiol 2004; 30:456-471.

20. Neuwelt EA, Varallyay CG, Manninger SN, Solymosi DN, Haluska M, Hunt MA, et al. The potential of ferumoxytol nanoparticle magnetic resonance imaging, perfusion, and angiography in central nervous system malignancy. Neurosurgery 2007; 60:601-612.

21. Nimsky C, Ganslandt O, Buchfelder M, Fahlbusch R. Glioma surgery evaluated by intraoperative low-field magnetic resonance imaging. Acta Neurochir Suppl 2003; 85:55-63.

22. Noël G, Guillevin R. [Delineation of glioblastoma, simplicity to complexity, the contribution of imaging]. Cancer Radiother 2011; 15:484-494.

23. Piccirillo SGM, Dietz S, Madhu B, Griffiths J, Price SJ, Collins VP, et al. Fluorescence-guided surgical sampling of glioblastoma identifies phenotypically distinct tumour-initiating cell populations in the tumour mass and margin. Br J Cancer 2012; 107:462-468.

24. Sanai N, Berger MS. Glioma extent of resection and its impact on patient outcome. Neurosurgery 2008; 62:753-64; discussion 264-6.

25. Sanai N, Polley M-Y, McDermott MW, Parsa AT, Berger MS. An extent of resection threshold for newly diagnosed glioblastomas. J Neurosurg 2011; 115:3-8. 
26. Schneider JP, Trantakis C, Rubach M, Schulz T, Dietrich J, Winkler D, et al. Intraoperative MRI to guide the resection of primary supratentorial glioblastoma multiforme-a quantitative radiological analysis. Neuroradiology 2005; 47:489-500.

27. Senft C, Bink A, Franz K, Vatter H, Gasser T, Seifert V. Intraoperative MRI guidance and extent of resection in glioma surgery: a randomised, controlled trial. The Lancet Oncology 2011; 12:997-1003.

28. Solheim O, Jakola AS, Gulati S, Salvesen O. Letter to the editor: Glioblastoma resection. J Neurosurg 2012;

29. Stupp R, Hegi ME, Mason WP, den Bent van MJ, Taphoorn MJB, Janzer RC, et al. Effects of radiotherapy with concomitant and adjuvant temozolomide versus radiotherapy alone on survival in glioblastoma in a randomised phase III study: 5-year analysis of the EORTC-NCIC trial. The Lancet Oncology 2009; 10:459-466.

30. Stupp R, Mason WP, den Bent van MJ, Weller M, Fisher B, Taphoorn MJB, et al. Radiotherapy plus concomitant and adjuvant temozolomide for glioblastoma. N Engl J Med 2005; 352:987-996.

31. Vogelbaum MA, Jost S, Aghi MK, Heimberger AB, Sampson JH, Wen PY, et al. Application of novel response/progression measures for surgically delivered therapies for gliomas: Response Assessment in Neuro-Oncology (RANO) Working Group. Neurosurgery 2012; 70:234-43- discussion 243-4.

32. Wen PY, Macdonald DR, Reardon DA, Cloughesy TF, Sorensen AG, Galanis E, et al. Updated response assessment criteria for high-grade gliomas: response assessment in neuro-oncology working group. J Clin Oncol 2010; 28:1963-1972.

33. Widhalm G, Minchev G, Woehrer A, Preusser M, Kiesel B, Furtner J, et al. Strong 5-aminolevulinic acid-induced fluorescence is a novel intraoperative marker for representative tissue samples in stereotactic brain tumor biopsies. Neurosurgical Review 2012; 35:381-391.

34. Willems PWA, Taphoorn MJB, Burger H, Berkelbach van der Sprenkel JW, Tulleken CAF. Effectiveness of neuronavigation in resecting solitary intracerebral contrast-enhancing tumors: a randomized controlled trial. J Neurosurg 2006; 104:360-368. 


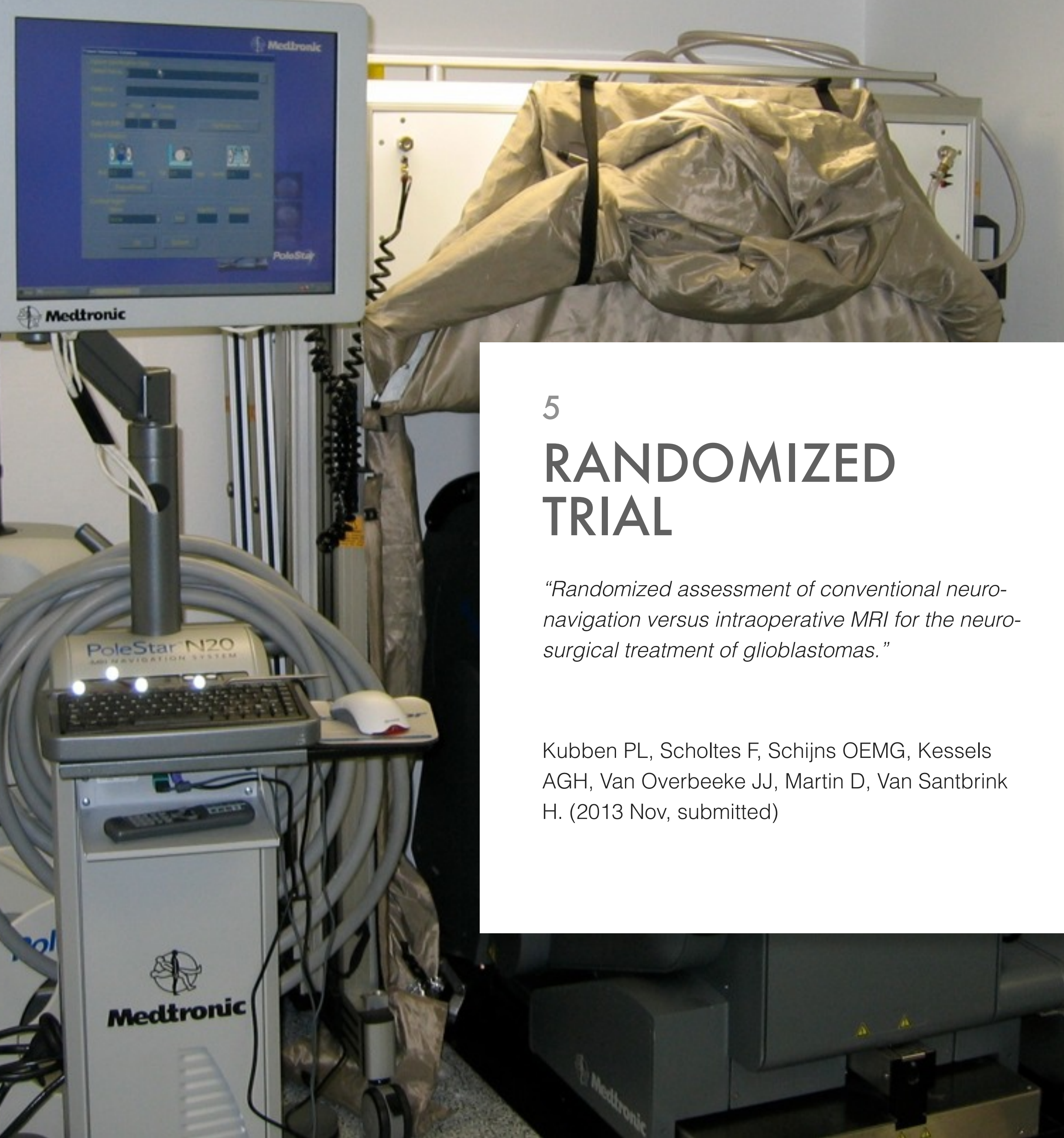




\section{INTRODUCTION}

Glioblastoma is an infiltrating malignant brain tumor. Standard treatment consists of surgery, radiotherapy and chemotherapy, leading to a median survival of 14.6 months.[21] The role of surgery is still under debate, though mounting evidence suggests that increased extent of tumor resection (EOTR) is associated with prolonged overall survival.[13]

Intraoperative MRI (iMRI) is a tool to maximize EOTR, but many reports on its efficacy suffer from methodological flaws.[5] A recently published randomized controlled trial (RCT) demonstrated that iMRI leads to increased EOTR in comparison to conventional surgery, comparable to the use of 5-aminolaevulinic acid.[17]

In this paper we present the results of an interim analysis of an international multicenter RCT that compares iMRI with conventional neuronavigation (CNN) for the neurosurgical treatment of glioblastoma. The objective is to assess whether iMRI-guided surgery leads to increased EOTR compared to cNN-guided surgery, and whether health-related quality of life (HRQOL) differs between these two approaches. We consulted the CONSORT (Consolidated Standards of Reporting Trials) 2010 guidelines for reporting of this trial.[16]

The study protocol is registered at ClinicalTrials.gov under number NCT00943007 and has been approved by the institutional ethics research boards of all participating centers. 


\section{METHODS}

\section{Participants}

We included 14 patients between March 2010 and July 2012 from all participating centers for the interim analysis of this RCT. Inclusion criteria were: supratentorial brain tumor - suspected to be glioblastoma on contrast enhanced diagnostic MRI, indication for gross total resection (GTR) of the tumor, age 18 years or older, WHO Performance Scale (WPS) 2 or better, ASA class 3 or better, adequate knowledge of the Dutch or French language, and informed consent. Exclusion criteria were: recurrent brain tumor, multiple brain tumor localizations, earlier skull radiotherapy, earlier chemotherapy for glioblastoma, chronic kidney disease or other renal function disorder, and a known MR-contrast allergy.

\section{Sample size}

To reduce the chance for type I errors (false positive) we used an alpha value of 0.05 . To reduce the chance for type II errors (false negative) we used a beta value of 0.2 leading to a power of 0.8 . We considered a $10 \%$ additional resection of the preoperative tumor volume as the minimal clinically relevant difference, with an estimated standard deviation of approximately $12 \%$.[12,15] This led to 23 patients in each treatment group. To compensate for loss to follow-up we intended to include a total of 54 patients for the complete study.

\section{Interventions}

\section{Experimental group}

Within 72 hours before surgery, a standard neuronavigation MRI scan was made at 1.5 Tesla (T) or 3T according to the local neurooncology protocol ( $\mathrm{T} 11 \mathrm{~mm}$ isovoxel after administration of a gadoliniumbased contrast agent). Patients were operated in the iMRI operating room setup, using the Stealth Station neuronavigation system, Medtronic Polestar N2O (0.15T) moveable magnet and the Starshield $\otimes$ tent as a mobile Faraday cage for shielding radiofrequency noise (Medtronic Navigation, Louisville, CO). The head was fixed in a MR compatible head holder, and specific MR compatible anaesthesia equipment was used (monitor, ECG pads, thermometer). No other precautions needed to be taken because of iMRI, and regular instruments could be used. A first non-enhanced T1 iMRI scan was usually made before starting surgery, but this was not mandatory. When the neurosurgeon 
considered glioblastoma resection to be complete, at least one intraoperative $\mathrm{T1} 7 \mathrm{~min} 4 \mathrm{~mm}$ scan was made after administration of contrast agent. In all but one case a so-called "double-dose" of contrast was used $(0.2 \mathrm{mmol} / \mathrm{kg})$. The neurosurgeon judged whether the scan demonstrated residual tumor, and decided either to continue resection if feasible and perform a new scan afterwards, or to finish the procedure after the intraoperative scan. If residual tumor was suspected, the "resectionscan-cycle" was repeated until the neurosurgeon considered glioblastoma resection to be maximal. Within 48 hours after surgery, a regular control MRI scan was made including a contrast-enhanced T1 multi-planar reconstruction MR scan (1 $\mathrm{mm}$ isovoxel).

\section{Control group}

The preoperative and postoperative imaging was the same as in the treatment group, only the surgical procedure differed. Patients were operated in a regular operating room setup using the Stealth Station neuronavigation system (Medtronic Navigation, Louisville, CO). The head was fixed in a standard Mayfield headclamp, and regular instruments were used. The surgery was finished at the point the neurosurgeon considered resection to be maximal.

\section{Outcomes}

\section{Primary endpoint}

Residual tumor volume (RTV) percentage is used as the primary endpoint to assess EOTR. Pre- and postoperative tumor volume was calculated by segmenting the hyperintense area on contrastenhanced T1 MRI (including enclosed central necrosis) and subtracting the hyperintense area on native T1 MRI to compensate for blood in the resection cavity. Measurements were performed using OsiriX software (Pixmeo SARL, Bernex, Switzerland) on Mac OS X using a Wacom Bamboo pen mouse for contour drawing. Postoperative tumor volume was divided by preoperative tumor volume to calculate the fraction of residual tumor volume. Multiplying the fraction with $100 \%$ provided the RTV. In formula:

$\mathrm{RTV}=($ postoperative contrast enhancement / preoperative contrast enhancement $){ }^{*} 100 \%$

\section{Secondary endpoints}

We recorded baseline demographic characteristics (sex, age, length, weight) and corticosteroid use on study entry. Complications were monitored on the case record form. WPS was scored one day before surgery, one day after surgery and before discharge from the hospital. We also recorded health-related quality of life (HRQOL). The patient was asked to complete the EORTC QLQ-C30 ques- 
tionnaire with the QLQ-BN20 brain cancer module, and the EuroQol EQ-5D questionnaires. The questionnaires were taken one day before surgery, before discharge and three months after surgery. Later we added "twelve months after surgery" to allow for a more long-term follow up as well. Raw scores were calculated and converted to standardized scores using a linear transformation. Overall survival was recorded for all patients.

\section{Randomization}

Patients were randomized and allocated to either the cNN or iMRI group. Randomization was performed by the first author using TEN-ALEA software for randomization in clinical trials. This software is provided by the Trans European Network (http://www.tenalea.com/) and maintenance for The Netherlands is performed by the Netherlands Cancer Institute (http://www.nki.nl/). No randomization blocks were used. The neurosurgeon could not be blinded for the procedure. We did not intend to blind the physicians on the ward, nor the patients. Volumetric assessment of pre- and postoperative tumor volume was performed by a single blinded researcher.

\section{Statistics}

Descriptive statistics were used to express RTV, WPS and survival. Univariate analysis was used to express the difference between both treatment groups regarding RTV (Mann Whitney test), WPS (Mann Whitney test) and survival (Kaplan Meier analysis using a log rank test). After checking whether the residuals of the regression analysis were normally distributed, multivariate analysis was used to express the independent contributions on the primary endpoint of age, sex, preoperative tumor volume, and histologically proven glioblastoma. For data entry and calculations, SPSS Statistics version 21 for Mac (IBM Corporation, Armonk, NY) was used. 


\section{RESULTS}

\section{Interim analysis}

The decision to perform an interim analysis was approved by the institutional ethics research boards of the coordinating center. It was not part of the original research protocol, which we modified for several reasons. The main reason was that we estimated that our minimally required difference of $10 \%$ would not be consistent with the actual results. Meanwhile iMRI did prolong surgery time by 1.5 - 2 hours. Also surgery was hindered by device-related limitations in the iMRI group, like suboptimal ergonomics and intermittent malfunction of the ultrasonic aspirator (CUSA Excel Ultrasonic Surgical Aspirator; Integra Radionics, Burlington, MA, USA) due to magnetic interference. Further, we noticed that patient inclusion took significantly longer than expected based on a previous study.[6] This was mainly related to the indication for GTR as an inclusion criterion: patients in which preoperatively was decided to leave a small area of contrast enhancement untouched because of the vicinity of eloquent areas or to avoid significant opening of the ventricular system, were excluded.

\section{Baseline data}

After randomization, 8 patients were assigned to the cNN group and 6 patients to the iMRI group. Participant flow is visualized in Figure 5.1. Mean age for the cNN group was $66 \pm 8$ years compared to $61 \pm 5$ years for the iMRI group. 11 patients were operated in the Netherlands and 3 in Belgium. In both treatment groups, one surgery was performed in the left hemisphere, all other surgeries were in the right hemisphere. Tumors were located in all lobes, except for in the iMRI group where no parietal tumors were included. Histopathology revealed glioblastoma in all patients except for two, having a metastasis: one in the cNN group and one in the iMRI group. All patients received radiotherapy postoperatively, and most received chemotherapy with temozolomide. Further details are provided in Table 5.1.

\section{Outcomes}

Outcomes were analysed for all patients according to an intention to treat principle. Imaging data were complete for all patients, but questionnaires contained some missing data (in particular HRQOL questionnaires). 


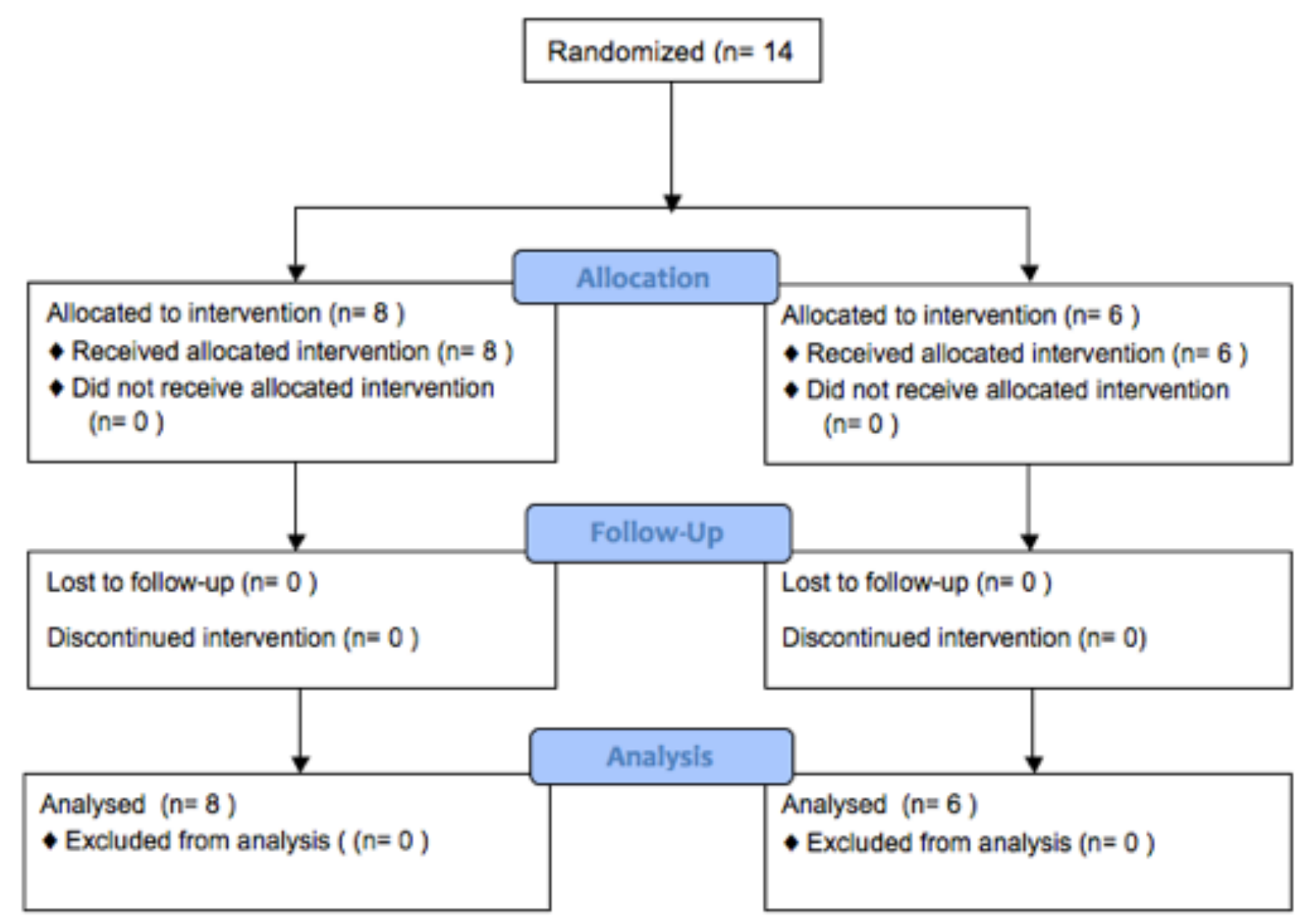

Figure 5.1: Participant flow in the study

Tumor volumetry results are displayed in Table 5.2. The first three columns represent volumetry results for preoperative contrast-enhanced MRI, postoperative native MRI and postoperative contrast-enhanced MRI. The "post gado only" column represents postoperative contrast enhancement (supposed to be residual tumor) and the last column displays rounded RTV values. Median RTV in the cNN group is $6.5 \%$ with an interquartile range of $2.5 \%-14.75 \%$. Median RTV in the iMRI group is $13 \%$ with an interquartile range of $3.75 \%-27.75 \%$. A Mann-Whitney test showed no statistically significant difference between these groups $(p=0.28)$. When both patients with a metastasis are excluded for further analysis, median RTV in the cNN group is $5 \%$ with an interquartile range of $2 \%$ $16 \%$ and median RTV in the iMRI group is $9 \%$ with an interquartile range of $3.5 \%-33.5 \%$. Also, for the glioblastoma population, a Mann Whitney test did not show a statistically significant difference between these groups $(p=0.43)$. Multivariate analysis does not reveal any significant influence of sex, age, preoperative tumor volume or histological diagnosis on RTV. 
Table 5.1: Study demographics

Parameter

Age (years)

Mean \pm SD

Sex

Male

Female

Center

MUMC

CHUL

Atrium MC

Hemisphere

Left

Right

Main lobe

Frontal

Parietal

Temporal

Occipital

ASA class preoperative

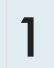

2

WPS preoperative

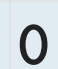

1

2

WPS postoperative

$$
\text { cNN }
$$

iMRI

$66 \pm 8$

$61 \pm 5$

4

4

3

3

$\begin{array}{ll}4 & 5 \\ 2 & 1 \\ 2 & 0\end{array}$

5

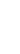


Table 5.1 (continued): Study demographics

\section{Parameter}

Values

cNN

iMRI

WPS discharge

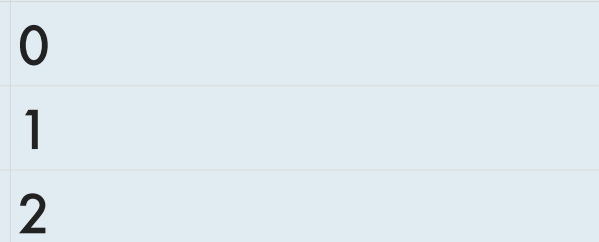

$\begin{array}{ll}2 & 1 \\ 4 & 3 \\ 1 & 2\end{array}$

Histological diagnosis

$\begin{array}{lll}\text { Glioblastoma } & 7 & 5\end{array}$

Metastasis

Postoperative

radiotherapy

Yes

8

6

No

0

0

Postoperative

temozolomide

Yes

5

4

No

3

2

Abbreviations: $A S A=$ American Society of Anaesthesiologists, Atrium MC $=$ Atrium Medical

Center, $\mathrm{CHUL}=$ Centre Hospitalier Universitaire de Liège, cNN = conventional neuronavigation, $i M R I=$ intraoperative MRI, MUMC = Maastricht University Medical Center, SD = Standard Deviation, WPS = WHO Performance Scale

Median preoperative WPS is 1 for both treatment groups, ranging from 0 to 2 . Median WPS one day postoperatively is 3 in the cNN group and 2,5 in the iMRI group, ranging from 1 to 3 in both groups. Median WPS before discharge (approximately one week after surgery in both groups) is 1 in both groups, ranging from 0 to 2. For the latter, data for one patient in the cNN group are missing. Using a Mann-Whitney test, mean rank for the WPS before discharge is 6.3 in the cNN group and 7.8 in the $i M R I$ group. The difference is not statistically significant $(p=0.53)$. 
Table 5.2: Tumor volumetry data

\begin{tabular}{|c|c|c|c|c|c|c|}
\hline Patient & Group & Pre Gado & Post Native & Post Gado & Post Gado Only & RTV \\
\hline RACL01 & $\mathrm{cNN}$ & 35.4 & 19.6 & 25.2 & 5.8 & 16 \\
\hline RACL02 & iMRI & 14.6 & 13.6 & 20.2 & 6.5 & 45 \\
\hline RACL03 & $\mathrm{cNN}$ & 11.0 & 12.7 & 13.3 & 0.5 & 5 \\
\hline RACM01 & cNN & 23.2 & 1.0 & 1.6 & 0.6 & 2 \\
\hline RACM02 & iMRI & 120.0 & 6.3 & 10.8 & 4.5 & 4 \\
\hline RACM03 & cNN & 28.6 & 1.2 & 3.5 & 2.3 & 8 \\
\hline RACMO4 & $\mathrm{cNN}$ & 30.9 & 0.4 & 1.7 & 1.3 & 4 \\
\hline RACM05 & cNN & 12.6 & 6.6 & 8.0 & 1.4 & 11 \\
\hline RACM06 & iMRI & 99.3 & 16.3 & 38.4 & 22.0 & 22 \\
\hline RACM07 & iMRI & 23.8 & 24.8 & 28.7 & 4.0 & 17 \\
\hline RACM08 & iMRI & 43.9 & 14.9 & 16.3 & 1.5 & 3 \\
\hline RACM09 & iMRI & 77.4 & 53.0 & 60.2 & 7.2 & 9 \\
\hline RACM10 & cNN & 154.0 & 48.5 & 52.1 & 3.6 & 2 \\
\hline RACM11 & cNN & 39.9 & 22.4 & 29.8 & 7.5 & 19 \\
\hline
\end{tabular}

Abbreviations: $\mathrm{cNN}=$ conventional neuronavigation, $\mathrm{Gado}=$ gadopentetate dimeglumine, $i M R I=$ intraoperative MRI, RTV = Residual Tumor Volume percentage

Median survival in the cNN group is 472 days, with an interquartile range of 244 - 619 days. Median survival in the iMRI group is 396 days, with an interquartile range of 191 - 599 days. The corresponding log rank $p$-value is 0.81 . When both patients with a metastasis are excluded for further analysis, median survival is 539 days in the cNN group and 396 days in the iMRI group, with a log rank p-value of 0.68. One glioblastoma patient in the cNN group opted for euthanasia eight months after surgery due to late disease-related complications. If this patient is excluded from the latter analysis, median survival remains unchanged, with a log rank $p$-value of 0.55 .

Figure 5.2a shows a Kaplan Meier curve that displays cumulative survival in time for both treatment groups, and figure 5.2b shows the same curve excluding patients with a metastasis. 


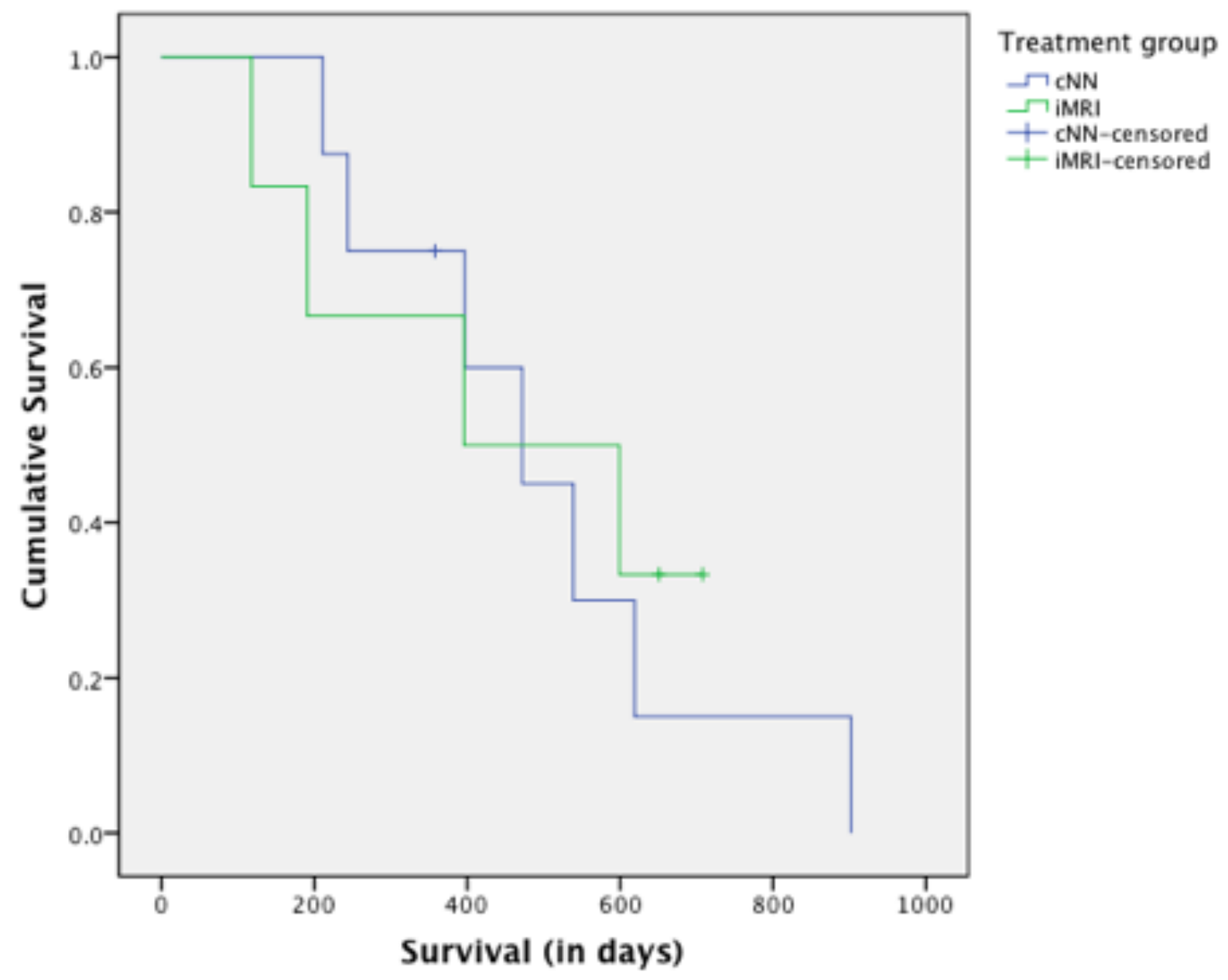

Figure 5.2a: Kaplan-Meier curve for all patients $(n=14)$

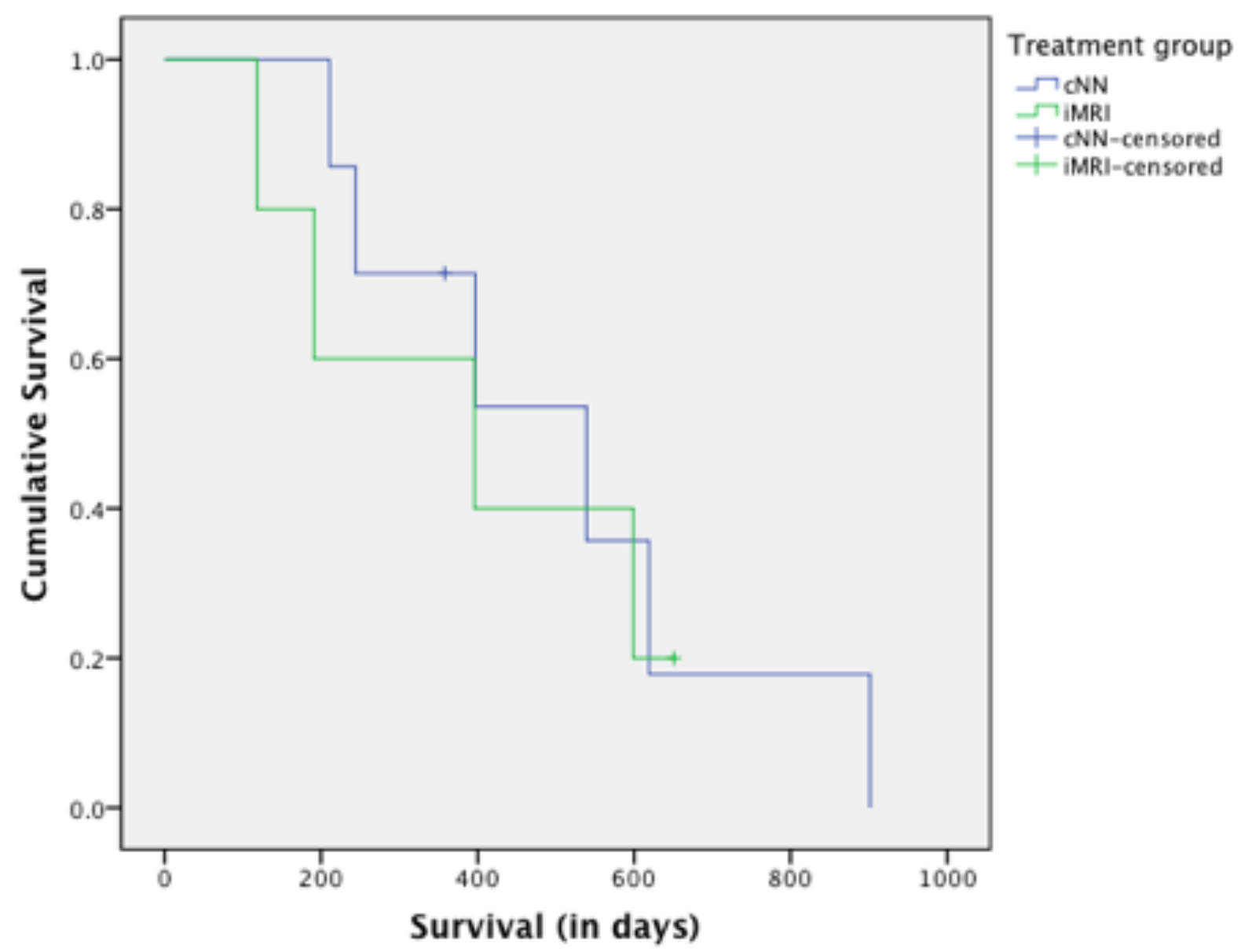

Figure 5.2b: Kaplan-Meier curve for glioblastoma patients only $(n=12)$ 
HRQOL scores are left out of this paper. Explorative data analysis does not show a clear advantage in $\mathrm{HRQOL}$ for either treatment group. After consultation of a health-technology assessment expert we decided to refrain from any further statistical analyses due to the small sample size.

\section{Adverse events}

One patient from the iMRI group suffered from postoperative hemorrhage which led to prolonged hospital stay and cognitive impairment. No other adverse events or serious adverse events were reported. 


\section{DISCUSSION}

Our study is the second randomized controlled trial on glioblastoma surgery using iMRI. This paper reports our results from an interim analysis of 14 patients. Volumetric assessment of the primary endpoint (RTV) does not show any advantage of iMRI-guided resection over cNN-guided resection: there is no statistical difference between both groups and mean RTV is higher in the iMRI group than in the cNN group. Clinical performance does not differ between both groups, and neither does survival in our population. Regarding HRQOL no firm conclusions could be drawn, although there is no clear tendency favoring one treatment group.

Study inclusion has been halted based on the results of this interim analysis. The combination of the minimal difference between iMRI-based treatment and cNN-based treatment on the one hand and the slow inclusion rate on the other hand would lead to a much longer timeframe to achieve the statistically significant results we initially aimed for. Based on the present interim analysis, however, we do not expect a different conclusion, and by the time that statistical significance would be reached, the technology used in this study is likely to be replaced by new devices. Therefore, the necessary additional investments associated with the investigated iMRI technology (mainly increased time consumption in the operating theatre) does not seem justified in our opinion, and could even be considered as ethically inadequate.

Despite the small sample size, there is still a clear conclusion from this interim analysis, which differs from the conclusion of the only other iMRI RCT by Senft et al.[17] These authors concluded that iMRIguided glioblastoma resection leads to GTR in $96 \%$ of cases compared to $68 \%$ in the control group $(p=0.023)$. Their control group consisted of a mixed population of $c N N$-guided resection and resection without neuronavigation. A post hoc exploratory analysis did not demonstrate a significant difference between both arms in the control group. Their definition of GTR was a tumor volume of less than $0.175 \mathrm{~cm} 3$ detected by a contrast enhanced T1-weighted MRI, the same as used by Stummer et al.[21,20] The median postoperative volume of contrast enhancing tissue was $0 \mathrm{~cm} 3$ in the iMRI group and $0.03 \mathrm{~cm} 3$ in the control group. No further details on their volumetry methodology is provided in the article. To our opinion, the authors' conclusion favoring iMRI-guided glioblastoma resection should be seen in the context of a minimal difference in postoperative tumor volume between both treatment groups. No significant difference exists in progression-free survival, and most importantly: there is a lack of a valid methodology for volumetric assessment of glioblastoma resection.[13,6,23] In our opinion, tumor volumes reported in the study of Senft are within the error limits of tumor volumetry. Further, a clear definition of "tumor" is one of the challenges to be solved 
besides improving accuracy of glioblastoma volumetry itself. Both these factors are key in defining a valid endpoint to measure glioblastoma resection.

The widely cited study from Lacroix et al states that a minimum of $98 \%$ glioblastoma resection is needed for survival benefit.[5,11] In that study, the authors used a method by which they assessed intraobserver agreement, but not interobserver agreement.[18] The same comments applies to the study by Kuhnt et al.[16,9] Sanai et al reported a minimum of $78 \%$ glioblastoma resection needed for survival benefit.[12,14,15] These authors also used a volumetric approach based on manual segmentation of contrast-enhancing tissue on T1-weighted imaging, but did not describe any correction for hyperintense signal on native T1-weighted imaging, and did not report on intraobserver and interobserver agreement of their methodology. There is an ongoing discussion regarding an optimal approach to define and measure glioblastoma resection, and no consensus has been reached yet.[6,9,14,7,23,19] Therefore, in contrast to studies on radiotherapy and chemotherapy,[24,22] neurosurgical studies cannot yet benefit from a valid endpoint to measure glioblastoma resection, which limits external validity of individual study results. To minimize the error in respect to our own published data we decided to have tumor volumes measured by a single (blinded) observer. We previously described this approach to have high intraobserver agreement, but low interobserver agreement.[6] Nevertheless, this type of approach is still the most commonly used approach to tumor volumetry in neurosurgical studies.[12,9,10]

A more fundamental discussion is to what extent further investments should be made to increase EOTR for glioblastoma surgery. Glioblastoma is a non-focal disease in which tumor cells can be found far beyond the contrast-enhancing area.[1,2,8,3] As long as there is no valid endpoint to quantify glioblastoma resection, no firm conclusions can be drawn regarding the added value of GTR (or CRET -complete resection of enhancing tumor- as described by Vogelbaum et al).[23] The minimal increase in patient survival after four decades of glioblastoma surgery (despite all sorts of technical equipment), in combination with no consensus on how to measure our results, may indicate that expanding technical innovation for glioblastoma resection should not have our highest priority at this moment.[4]

\section{Limitations}

The main limitation of this study is the lack of a valid endpoint for glioblastoma volumetry, as discussed before. We used the best available tumor volume definition but, still, our volumetry results should not be considered as absolute values, but more as a tendency in which the exact quantification can differ from the data provided in this article. Nevertheless, based on our previous study that analyzed intraobserver and interobserver agreement of glioblastoma volumetry, we are confident that the tendency reported in this article is a correct reflection of the results.[6] 
Our interim analysis has a small sample size which limits statistical significance in our endpoints. In particular, differences between HRQOL in both treatments groups cannot be tested due to the small sample size aggravated by missing data.

Finally it should be noted that our data result from an $0.15 \mathrm{~T}$ iMRI system with its specific advantages and disadvantages. We do not expect different results on high-field strength systems, however, only because of a higher spatial resolution, but the use of other imaging modalities might lead to different conclusions. We also cannot make a valid comparison with 5-ALA guided surgery,[20] which might be an interesting control group for a future comparative study with iMRI. 


\section{CONCLUSION}

This interim analysis of a RCT on iMRI-guided glioblastoma resection compared to cNN-guided glioblastoma resection does not show an advantage with respect to EOTR, clinical performance and overall survival for the iMRI group. Although the lack of a valid endpoint to measure glioblastoma resection prevents firm conclusions to be drawn, the added value of (ultra-low field strength) iMRI for this non-focal disease is to be debated seriously and does not seem to be cost-effective. Before evaluating new technological developments, research of the near future should primarily focus on developing a valid endpoint to compare surgical results, between different centers and with different technologies, as well as the assessment of survival benefits with increased EOTR. 


\section{REFERENCES}

1. Claes A, Idema AJ, Wesseling P. Diffuse glioma growth: a guerilla war. Acta Neuropathol 2007; 114:443-458.

2. Fan G, Sun B, Wu Z, Guo Q, Guo Y. In vivo single-voxel proton MR spectroscopy in the differentiation of high-grade gliomas and solitary metastases. Clinical radiology 2004; 59:77-85.

3. Kelly PJ, Daumas-Duport C, Kispert DB, Kall BA, Scheithauer BW, Illig JJ. Imaging-based stereotaxic serial biopsies in untreated intracranial glial neoplasms. J Neurosurg 1987; 66:865-874.

4. Kelly PJ. Gliomas: Survival, origin and early detection. Surg Neurol Int 2010; 1:96.

5. Kubben PL, Meulen Ter KJ, Schijns OE, Laak-Poort Ter MP, van Overbeeke JJ, van Santbrink H. Intraoperative MRI-guided resection of glioblastoma multiforme: a systematic review. The Lancet Oncology $2011 ; 12: 1062-1070$.

6. Kubben PL, Postma AA, Kessels AGH, van Overbeeke JJ, van Santbrink H. Intraobserver and interobserver agreement in volumetric assessment of glioblastoma multiforme resection. Neurosurgery 2010; 67:1329-1334.

7. Kubben P, van Santbrink H. Glioblastoma resection. J Neurosurg 2012; 116:1163-4- author reply 1167-8.

8. Kubben P, Wesseling P, Lammens M, Schijns OMG, Laak Poort ter M, van Overbeeke J, et al. Correlation between contrast enhancement on intraoperative magnetic resonance imaging and histopathology in glioblastoma. Surg Neurol Int 2012; 3:158.

9. Kuhnt D, Becker A, Ganslandt O, Bauer M, Buchfelder M, Nimsky C. Correlation of the extent of tumor volume resection and patient survival in surgery of glioblastoma multiforme with high-field intraoperative MRI guidance. Neuro-oncology 2011; 13:1339-1348.

10. Kuhnt D, Ganslandt O, Schlaffer S-M, Buchfelder M, Nimsky C. Quantification of Glioma Removal by Intraoperative High-Field Magnetic Resonance Imaging: An Update. Neurosurgery 2011; 69:852863.

11. Lacroix M, ea. A multivariate analysis of 416 patients with glioblastoma

multiforme: prognosis, extent of resection, and survival. J Neurosurg 2001; 95:190-198. 
12. Nimsky C, Fujita A, Ganslandt O, Keller Von B, Fahlbusch R. Volumetric Assessment of Glioma Removal by Intraoperative High-field Magnetic Resonance Imaging. Neurosurgery 2004;:358-371.

13. Sanai N, Berger MS. Glioma extent of resection and its impact on patient outcome. Neurosurgery 2008; 62:753-64; discussion 264-6.

14. Sanai N, Polley M-Y, McDermott MW, Parsa AT, Berger MS. An extent of resection threshold for newly diagnosed glioblastomas. J Neurosurg 2011; 115:3-8.

15. Schneider JP, Trantakis C, Rubach M, Schulz T, Dietrich J, Winkler D, et al. Intraoperative MRI to guide the resection of primary supratentorial glioblastoma multiforme-a quantitative radiological analysis. Neuroradiology 2005; 47:489-500.

16. Schulz KF, Altman DG, Moher D, CONSORT Group. CONSORT 2010 statement: updated guidelines for reporting parallel group randomised trials. BMJ 2010; 340:c332.

17. Senft C, Bink A, Franz K, Vatter H, Gasser T, Seifert V. Intraoperative MRI guidance and extent of resection in glioma surgery: a randomised, controlled trial. The Lancet Oncology 2011; 12:997-1003.

18. Shi WM, Wildrick DM, Sawaya R. Volumetric measurement of brain tumors from MR imaging. J Neurooncol 1998; 37:87-93.

19. Solheim O, Jakola AS, Gulati S, Salvesen O. Glioblastoma resection. J Neurosurg 2012; 116:1164-6- author reply 1167-8.

20. Stummer W, Pichlmeier U, Meinel T, Wiestler O, Zanella F, Reulen H. Fluorescence-guided surgery with 5-aminolevulinic acid for resection of malignant glioma: a randomised controlled multicentre phase III trial. The Lancet Oncology 2006; 7:392-401.

21. Stupp R, Mason WP, den Bent van MJ, Weller M, Fisher B, Taphoorn MJB, et al. Radiotherapy plus concomitant and adjuvant temozolomide for glioblastoma. N Engl J Med 2005; 352:987-996.

22. Therasse P, Arbuck SG, Eisenhauer EA, Wanders J, Kaplan RS, Rubinstein L, et al. New guidelines to evaluate the response to treatment in solid tumors. European Organization for Research and Treatment of Cancer, National Cancer Institute of the United States, National Cancer Institute of Canada. J Natl Cancer Inst 2000; 92:205-216.

23. Vogelbaum MA, Jost S, Aghi MK, Heimberger AB, Sampson JH, Wen PY, et al. Application of novel response/progression measures for surgically delivered therapies for gliomas: Response Assessment in Neuro-Oncology (RANO) Working Group. Neurosurgery 2012; 70:234-43- discussion $243-4$. 
24. Wen PY, Macdonald DR, Reardon DA, Cloughesy TF, Sorensen AG, Galanis E, et al. Updated response assessment criteria for high-grade gliomas: response assessment in neuro-oncology working group. J Clin Oncol 2010; 28:1963-1972. 


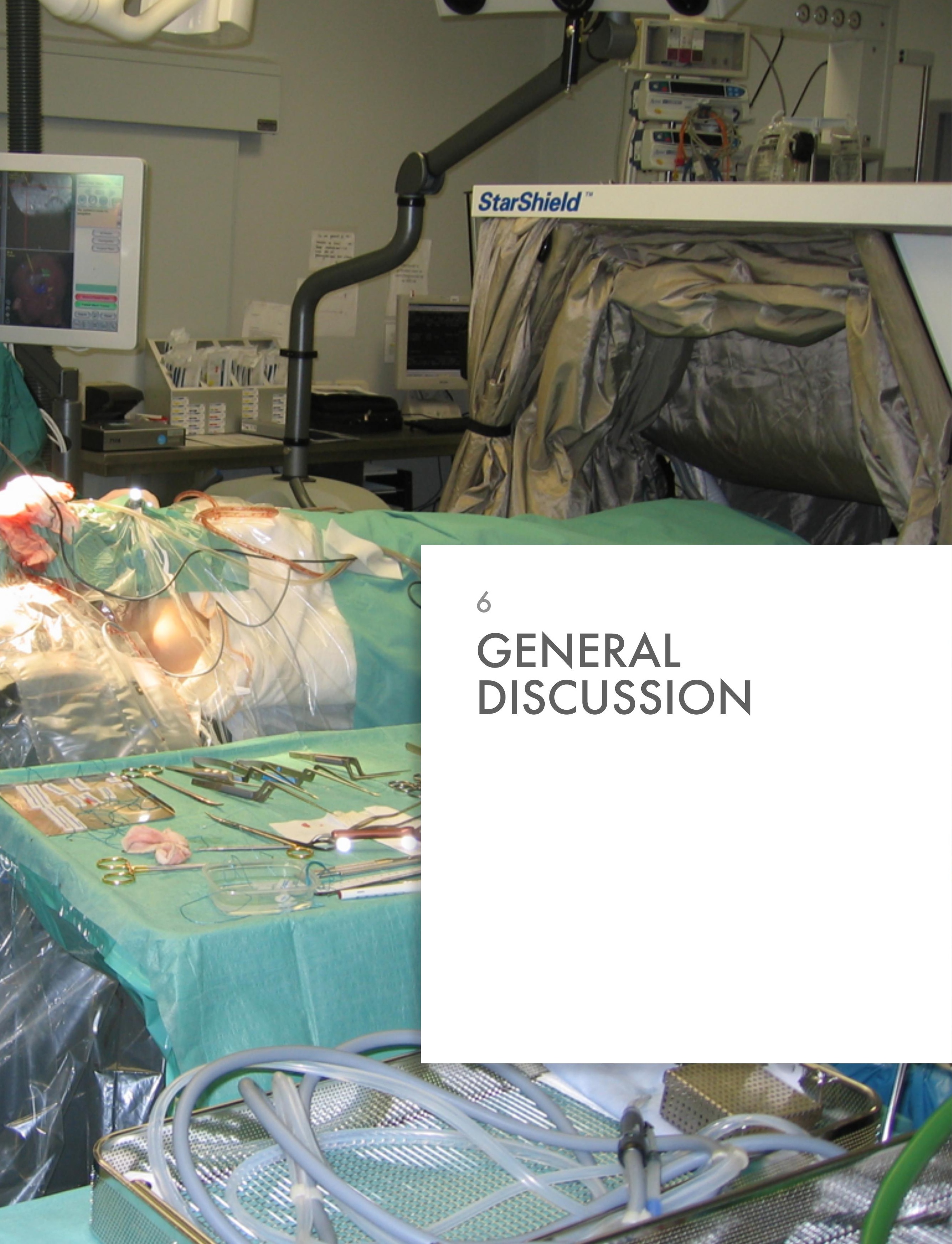




\section{DISCUSSION}

\section{Intraoperative MRI}

Intraoperative MRI (iMRI) was introduced to be able to navigate on updated images during neurosurgical procedures.[1] Conventional neuronavigation (CNN) is useful for planning the approach of a procedure, but is not capable of correcting for so-called "brain shift" that occurs intraoperatively. Although mathematical models have been applied on preoperative images to correct for brain shift,[2,23] they do not reflect a "live" view of the current situation. Depending on the sort of iMRI, this technology can offer this "live" view during surgery, but most sorts of iMRI require the surgical procedure to be stopped in order to acquire new images. The first system by General Electric, nicknamed the "double doughnut" for its physical appearance, offered 0.5 Tesla $(T)$ field strength, and is today considered to be a low-field strength device. The surgeon was operating between the two vertically placed magnets (the "doughnuts") which was ergonomically not the most comfortable position, but at least it did offer "live" (real-time) imaging.[1] Other systems as developed by e.g. Philips, Siemens and Medtronic do not allow real-time imaging but after a few minutes scanning time neuronavigation images can be updated and surgery can be continued. $[6,24,26,8]$ Technology has evolved into two directions: high-field strength (1.5-3T) or low-field strength devices. High-field strength devices are more expensive (estimated cost around 4-5 million euro) compared to low-field strength devices (estimated cost around 1 million euro). Yearly maintenance is estimated to be approximately $10 \%$ of the acquisition cost. High-field devices offer better spatial resolution which results in better image quality, and they offer multimodality imaging (e.g. diffusion tensor imaging, magnetic resonance spectroscopy). In contrast, such devices are more heavy which places a higher demand on construction of the operating theatre, which is sometimes rebuilt in the basement of the hospital because the floor of the regular operating theatre cannot carry the weight. Also dedicated MR-compatible instruments are required in the operating room. To what extent these high-field strength devices limit surgical workflow is debatable: proponents of low-field strength imaging have been using this as a parameter in favor of low-field strength iMRI, but to our experience low-field strength iMRI suffers from workflow issues as well. The lower spatial resolution is not a practical limitation when performing high grade glioma surgery, whereas performing low-grade glioma surgery with low-field strength iMRI can be more troublesome. On the ultra low-field strength iMRI device (0.15T) used for our research this is aggravated by the decreased signal-to-noise ratio of T2-weighted MRI compared to T1-weighted MRI. Pituitary surgery also takes a learning curve with respect to judging residual pituitary adenoma on contrast-enhanced images, and for this aspect the relatively low spatial resolution is a part of the challenge. Obviously the lower cost of (ultra) low-field strength iMRI is an important reason in favor of these devices. It is less troublesome to rebuild a regular operating room 
into an iMRI suite, especially when local Faraday shielding is used (removing the need to build shielding into the walls of the room). It is hard to discuss cost-effectiveness only by taking surgical use of iMRI into account, because high-field strength devices are often integrated into a shared-room concept, in which the radiology department can use the (i)MRI device when it is not used for surgical procedures. The literature on cost-effectiveness for these devices is limited and inconclusive, although a recent study states that "there is no adequate justification for the widespread installation of low-field strength iMRI in its current development state".[7,17] This conclusion is in line with other centers' decisions to discontinue the use of iMRI, in particular (ultra) low-field strength iMRI (personal communication).

\section{Criticism}

High grade glioma is one of the major indications for which $\mathrm{MRI}$ is used. The introduction of this technology dates back before the class 1 evidence for 5-aminolevulinic acid (5-ALA),[25] which offers an alternative solution that is at least as effective as iMRI but does not require major investments upfront. [22] This thesis focuses on glioblastoma surgery with ultra low-field strength $\mathrm{iMRI}$, and the opinions expressed are based on 8 years of personal experience with the device and communications with other users at various sites.

\section{Patient installation}

During patient installation a compromise must be sought between optimal surgical access and a position which allows the head to fit between the magnets. The head clamp has a fixed size, which means that three pins have to be screwed into the skull by torque screw drivers. This is more cumbersome and takes more time than a regular head clamp. Further it is important that the surgical site is approximately centered between the magnets for optimal image quality. This means that for tumors located near the skull base the magnet has to be "moved in" towards the feet, and collides with the shoulders (particularly in people who have a rather "short neck"). A little pressure on the shoulders during scanning (circa 15 minutes before pressure is released) is acceptable, but too much pressure should be avoided to prevent injury to the brachial plexus. Therefore it can be necessary to use a lateral position (in contrast to supine or prone), which prolongs setup time before surgery.

\section{Compatible equipment}

For $0.15 \mathrm{~T}$ iMRI regular surgical instruments can be used, although they can be attracted towards the magnet (causing frustration for the scrub nurse who tries to keep the instruments on her tables ordered). In the surgical field some interference caused by the magnet is noticable, but the only difficulty during surgery has been the handling of the needle when suturing the wound. After surgery the 
instruments had to be taken to a dedicated demagnetizer to avoid persistent magnetism in a next procedure (e.g. clipping an aneurysm, during which we discovered the phenomenon). The anaesthesia monitor has to be MR-compatible because the device will disturb signals on non-compatible monitors. Also MR-compatible thermometers and ECG stickers have to be used. Obviously the ventilation tube should not contain any metal: a reinforced tube once accidentally inserted did seriously decrease image quality, but fortunately did not harm the patient. Most of these issues happened in the first 1-2 years after installation, afterwards the same team was present during iMRI procedures which helped to avoid many of these. For the local Faraday shielding a dedicated floor plate is present in the operating room, and non-visible corrosion also has been known to reduce image quality. Changing the floor cleaning program and having it prepared before iMRI surgery eradicated this problem.

\section{Ergonomics}

During the surgical procedure the iMRI system remains in place, although the magnets are lowered before surgery and raised before scanning. Even with the magnets in their lowest and most inward position, access to the patient has some restrictions. If the surgeon is in a standing position, there might be a need to bend slightly forward for a longer period because the magnets are in the way. If the surgeon is in a sitting position, the minimal table height required by the magnet might be too heigh to work comfortably. Further access to the patient is restricted by the magnet's base. Another issue of concern is the lack of MR-compatible retractors. Surgeons who prefer to work with an halo-ring and retractors will notice that there is no MR-compatible alternative for the 0.15T iMRI device as used by our hospital. For some of the staff members this has been the most important reason why not to work with the iMRI device.

\section{Outcome measurement}

When new technology is introduced into clinical care its added value towards standard treatment should be assessed. For (neuro)surgical devices that are intended to help increasing extent of tumor resection (EOTR) in a safe and reliable manner, EOTR should be assessed. The use of (progressionfree) survival as a study endpoint clearly has added value, but it is influenced by several postoperative parameters which might be uncorrelated to the surgical procedure and associated outcome itself. Many neurosurgical studies that evaluate new technology with respect to EOTR use a volumetric approach towards tumor volume. In contrast to radiotherapy and chemotherapy which cause an approximately spherical decrease in tumor size, neurosurgical resection can cause a border of contrast-enhancing tissue to be visible on postoperative contrast-enhanced T1-weighted MRI. This cannot be assessed with the same tools that are used to assess effects of radiotherapy or chemotherapy (like the MacDonalds criteria, RECIST or the RANO advice).[16,27,29] Although volumetry can theoretically give a much more precise estimate of residual tumor volume, this 
approach cannot considered to be valid yet.[13,28] Intraobserver agreement is good for both preoperative and postoperative tumor volume, but interobserver agreement is only good for preoperative tumor volume. For postoperative tumor volume, and hence for residual tumor volume, interobserver agreement is low. If volumetry is to be chosen for outcome assessment, having all measurements done by one observer (blinded for treatment group) is currently the best option. This has the limitation that the numbers found cannot be interpreted as absolute numbers. To our opinion the "magic" 98\% as a minimally required EOTR to improve survival, postulated by Lacroix et al.,[15] is not to be considered as any magic at all. Ten years later, new data were published by other groups with new percentages varying between $78 \%$ and $98 \%$.[21,14] These studies used different methods of tumor delineation, performed by different observers, and none of these studies assessed interobserver agreement.

Therefore no firm conclusions can be drawn by volumetry-based (i)MRI studies. [18,14,22] The randomized trial on this topic published by Senft et al describes a volumetry-based median difference of $0.03 \mathrm{~cm} 3(p=0.0015)$ between the iMRI group and cNN group, which might be as well in the measurement margin. Besides it is doubtful whether this small difference is clinically relevant, knowing that there are plenty of tumor cells present outside the contrast-enhancing area in patients with glioblastoma.

\section{Correlation with histology}

Kelly published data on serial sampling in stereotactic biopsies of untreated glioblastoma almost thirty years ago.[11] Since then it is well known that tumor cells are present outside the contrast enhancing area as visible on CT or MR imaging. Brain surgery inherently involves an iatrogenic damage to the blood-brain barrier and studies have been published describing residual contrast enhancement after repeated intraoperative contrast administration.[12,9] Therefore we systematically evaluated the correlation between contrast enhancement on T1-weighted iMRI and histopathological characteristics scored by two neurpathologists in a semi-quantitative manner. Essentially this study confirms that clearly visible contrast-enhancement is specific for tumor residual, but a small border of linear enhancement at the border of the resection cavity is less specific. This is in line with the conclusion from Ekinci et al. based on preoperative and postoperative MRI.[5] If there is no visible contrast enhancement, chances are still around 50\% (varying between 39\%-70\% depending on definitions of tumor and contrast enhancement) that there is tumor tissue present which exhibits high grade glioma features. Our study is limited to assessment of residual contrast enhancement (suspect for tumor) using iMRI. A recent study investigated the use of 5-ALA as a marker for representative stereotactic biopsy samples in several types of tumor, and found better values compared with our study for specificity (1.00) and sensitivity (0.69) in case of strong 5-ALA fluorescence.[30] Another study used 5-ALA to differentiate between necrosis, (fluorescent) "tumor cells", and (nonfluorescent) "margin cells". They found that margin cells do not possess a 'stem-cell molecular signature' but retain tumor- 
initiating ability in vivo.[20] This finding is important, as it contradicts the belief that especially these margin cells are particularly tumorigenic. To what extent 5-ALA fluorescence correlates with contrast enhancement on iMRI (and therefore - indirectly - with tumorigenicity of cells at the resection cavity, is being investigated (Senft et al., personal communication September 2012). The consequences of these findings on surgical strategy regarding EOTR remain to be seen. If we conclude that: (1) there are many tumor cells present outside the contrast enhancing area, (2) the small border of contrast enhancment at the edge of the resection cavity does not cleary correspond with tumor, and (3) the tumor cells that are present at the resection border are not more tumorigenic than other tumor cells, it is highly debatable to what extent a "gross total resection" or "complete resection of enhancing tumor" should be the surgical goal. Also, there is well know non-overlap between contrast enhancement on MRI and e.g. positron emitted tomography scans.[10,19] This illustrates another important issue when discussing glioblastoma treatment: we actually do not know well how to define "glioblastoma" based on imaging features. Without a clear definition of what our surgical target should be, it is difficult to discuss how to improve interobserver agreement of volumetry, and comparing different technical-surgical strategies with outcome becomes a daunting task.

\section{Added value}

In our randomized trial we could not confirm the results from Senft et al. that indicate the added value of iMRI compared to cNN in patients with glioblastoma. We did not find less residual tumor volume in our iMRI group, nor did we find improved clinical performance, health-related quality of life or prolonged survival. To our opinion the added value of ultra low-field strength iMRI for glioblastoma should not be sought in maximizing resection by chasing after the small border of contrast enhancement in the resection cavity. We also do not think that patients who show such an area of contrast enhancement on postoperative MRI should be reoperated. For glioblastoma surgery, 5-ALA might be a better approach when complete resection of enhancing tumor is the surgical goal. Clearly iMRI can have added value as a learning tool, allowing for direct feedback during the surgical procedure. Whether this justifies the high cost involved, is a different question which might have a negative answer in the current financial situation worldwide.

\section{Looking forward}

A few steps are indicated for the future of glioblastoma surgery. First, we need to define what we consider to be "tumor" eligible for surgical resection based on imaging techniques, and what techniques to use for this preoperative workup. Next, we need to develop and validate a primary endpoint that can be used in neurosurgical studies. Then we can start comparative studies and evaluate to what extent neurosurgical resection should be performed in order for the patient to benefit in quality of life 
(an endpoint used too little) and in survival. More advanced health-technology assessment methodology can be implemented for a balance between quality of life, survival and cost. The "functional neuro-oncology approach" with supramaximal resections as proposed by Duffau for low-grade glioma offers an alternative way to look at glioblastoma surgery.[3,4] Still, it is hard to evaluate without a clear endpoint and a valid way to measure this. For neurosurgical studies, it makes sense to use extent of tumor resection as the primary endpoint, because all sorts of postoperative strategies may vary and influence other endpoints.

More philosophically, the role of EOTR in glioblastoma treatment is still debatable. If a preoperative tumor consists of $10^{11}$ cells, a gross total resection of $99 \%$ still leaves $10^{9}$ cells behind. The cure for glioblastoma won't be neurosurgical resection, and within this perspective all expensive technology that attempts to increase extent of tumor resection should be evaluated critically.

This thesis does not evaluate other indications for ultra low-field strength iMRI and it does not evaluate other sorts of iMRI, in particular high-field strength devices. In particular the latter might be interesting for low-grade glioma surgery, although it has to be considered to place such an expensive device in one dedicated center to which patients are referred from a larger area. Still, to be able to evaluate this technology, the same concerns as expressed above for glioblastoma apply.

For now, it can be perfectly justified to attempt complete resection of enhancing tumor in glioblastoma patients as long as they are not further harmed by the surgical procedure. However, the added value of ultra low-field strength iMRI does not seem to justify the cost, and it is not mandatory to resect that last small border of contrast enhancement (as visible on T1-weighted imaging) at the border of the resection cavity. Neither does the latter justify a second-look procedure. And currently, any sort of absolute "magic" number for a minimally required extent of glioblastoma resection threshold that leads to a miraculous increase in survival can be considered a fairy tale instead of rock-solid science.

The end. 


\section{REFERENCES}

1. Black PM, Moriarty T, Alexander E, Stieg P, Woodard EJ, Gleason PL, et al. Development and implementation of intraoperative magnetic resonance imaging and its neurosurgical applications. Neurosurgery $1997 ;$ 41:831-42- discussion 842-5.

2. Carter T, Sermesant M, Cash D, Barratt D, Tanner C, Hawkes D. Application of soft tissue modelling to image-guided surgery. Medical Engineering \& Physics 2005; 27:893-909.

3. Duffau H. Surgery of low-grade gliomas: towards a 'functional neurooncology'. Curr Opin Oncol 2009; 21:543-549.

4. Duffau $\mathrm{H}$. The challenge to remove diffuse low-grade gliomas while preserving brain functions. Acta Neurochirurgica 2012; 54:569-574.

5. Ekinci G, Akpinar IN, Baltacioğlu F, Erzen C, Kiliç T, Elmaci I, et al. Early-postoperative magnetic resonance imaging in glial tumors: prediction of tumor regrowth and recurrence. Eur J Radiol 2003; 45:99-107.

6. Hadani M. Novel, Compact, Intraoperative Magnetic Resonance Imaging-guided System for Conventional Neurosurgical Operating Rooms. Neurosurgery 2001;:11.

7. Hall WA, Kowalik K, Liu H, Truwit CL, Kucharezyk J. Costs and benefits of intraoperative MRguided brain tumor resection. Acta Neurochir Suppl 2003; 85:137-142.

8. Hall WA, Liu H, Martin AJ, Pozza CH, Maxwell RE, Truwit CL. Safety, efficacy, and functionality of high-field strength interventional magnetic resonance imaging for neurosurgery. Neurosurgery 2000; 46:632-41; discussion 641-2.

9. Hall WA, Galicich W, Bergman T, Truwit CL. 3-Tesla intraoperative MR imaging for neurosurgery. J Neurooncol 2006; 77:297-303.

10. Holodny Al, Makeyev S, Beattie BJ, Riad S, Blasberg RG. Apparent diffusion coefficient of glial neoplasms: correlation with fluorodeoxyglucose-positron-emission tomography and gadoliniumenhanced MR imaging. AJNR Am J Neuroradiol 2010; 31:1042-1048.

11. Kelly PJ, Daumas-Duport C, Kispert DB, Kall BA, Scheithauer BW, Illig JJ. Imaging-based stereotaxic serial biopsies in untreated intracranial glial neoplasms. J Neurosurg 1987; 66:865-874. 
12. Knauth M. Surgically Induced Intracranial Contrast Enhancement: Potential Source of Diagnostic Error in Intraoperative MR Imaging. AJNR 1999;:7.

13. Kubben PL, Postma AA, Kessels AGH, van Overbeeke JJ, van Santbrink H. Intraobserver and interobserver agreement in volumetric assessment of glioblastoma multiforme resection. Neurosurgery 2010; 67:1329-1334.

14. Kuhnt D, Becker A, Ganslandt O, Bauer M, Buchfelder M, Nimsky C. Correlation of the extent of tumor volume resection and patient survival in surgery of glioblastoma multiforme with high-field intraoperative MRI guidance. Neuro-oncology 2011;

15. Lacroix M, ea. A multivariate analysis of 416 patients with glioblastoma

multiforme: prognosis, extent of resection, and survival. J Neurosurg 2001; 95:190-198.

16. Macdonald DR, Cascino TL, Schold SC, Cairncross JG. Response criteria for phase II studies of supratentorial malignant glioma. J Clin Oncol 1990; 8:1277-1280.

17. Makary M, Chiocca EA, Erminy N, Antor M, Bergese SD, Abdel-Rasoul M, et al. Clinical and economic outcomes of low-field intraoperative MRI-guided tumor resection neurosurgery. J Magn Reson Imaging 2011; 34:1022-1030.

18. Nimsky C, Fujita A, Ganslandt O, Keller Von B, Fahlbusch R. Volumetric Assessment of Glioma Removal by Intraoperative High-field Magnetic Resonance Imaging. Neurosurgery 2004;:358-371.

19. Noël G, Guillevin R. [Delineation of glioblastoma, simplicity to complexity, the contribution of imaging]. Cancer Radiother 2011; 15:484-494.

20. Piccirillo SGM, Dietz S, Madhu B, Griffiths J, Price SJ, Collins VP, et al. Fluorescence-guided surgical sampling of glioblastoma identifies phenotypically distinct tumour-initiating cell populations in the tumour mass and margin. $\mathrm{Br} J$ Cancer 2012; 107:462-468.

21. Sanai N, Polley M-Y, McDermott MW, Parsa AT, Berger MS. An extent of resection threshold for newly diagnosed glioblastomas. J Neurosurg 2011; 115:3-8.

22. Senft C, Bink A, Franz K, Vatter H, Gasser T, Seifert V. Intraoperative MRI guidance and extent of resection in glioma surgery: a randomised, controlled trial. The Lancet Oncology 2011; 12:997-1003.

23. Skrinjar O. Model-drivenbrainshift compensation. Med Image Analysis 2002;:13.

24. Steinmeier R, Fahlbusch R, Ganslandt O, Nimsky C, Buchfelder M, Kaus M, et al. Intraoperative magnetic resonance imaging with the magnetom open scanner: concepts, neurosurgical indications, and procedures: a preliminary report. Neurosurgery 1998; 43:739-47- discussion 747-8. 
25. Stummer W, Pichlmeier U, Meinel T, Wiestler O, Zanella F, Reulen H. Fluorescence-guided surgery with 5-aminolevulinic acid for resection of malignant glioma: a randomised controlled multicentre phase III trial. The Lancet Oncology 2006; 7:392-401.

26. Sutherland GR. A mobile high-field magnetic resonance system for neurosurgery. J Neurosurg $1999 ;: 10$.

27. Therasse P, Arbuck SG, Eisenhauer EA, Wanders J, Kaplan RS, Rubinstein L, et al. New guidelines to evaluate the response to treatment in solid tumors. European Organization for Research and Treatment of Cancer, National Cancer Institute of the United States, National Cancer Institute of Canada. J Natl Cancer Inst 2000; 92:205-216.

28. Vogelbaum MA, Jost S, Aghi MK, Heimberger AB, Sampson JH, Wen PY, et al. Application of novel response/progression measures for surgically delivered therapies for gliomas: Response Assessment in Neuro-Oncology (RANO) Working Group. Neurosurgery 2012; 70:234-43- discussion 243-4.

29. Wen PY, Macdonald DR, Reardon DA, Cloughesy TF, Sorensen AG, Galanis E, et al. Updated response assessment criteria for high-grade gliomas: response assessment in neuro-oncology working group. J Clin Oncol 2010; 28:1963-1972.

30. Widhalm G, Minchev G, Woehrer A, Preusser M, Kiesel B, Furtner J, et al. Strong 5-aminolevulinic acid-induced fluorescence is a novel intraoperative marker for representative tissue samples in stereotactic brain tumor biopsies. Neurosurgical Review 2012; 35:381-391. 
70 ? ( $\operatorname{sg} \theta$

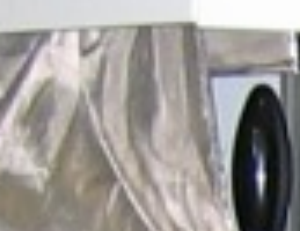

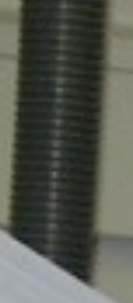

$x_{-10}$

soly

Un

and

Q311

Axisy

4henif

II

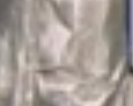

(2)

axy

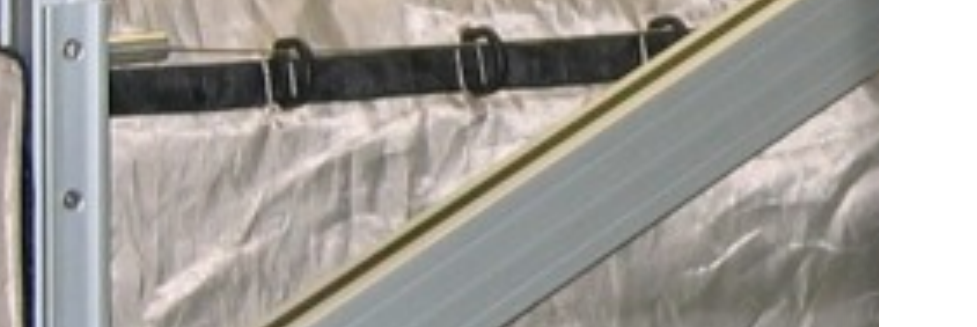

7

SUMMARY

SAMENVATTING

1) $12 \times$
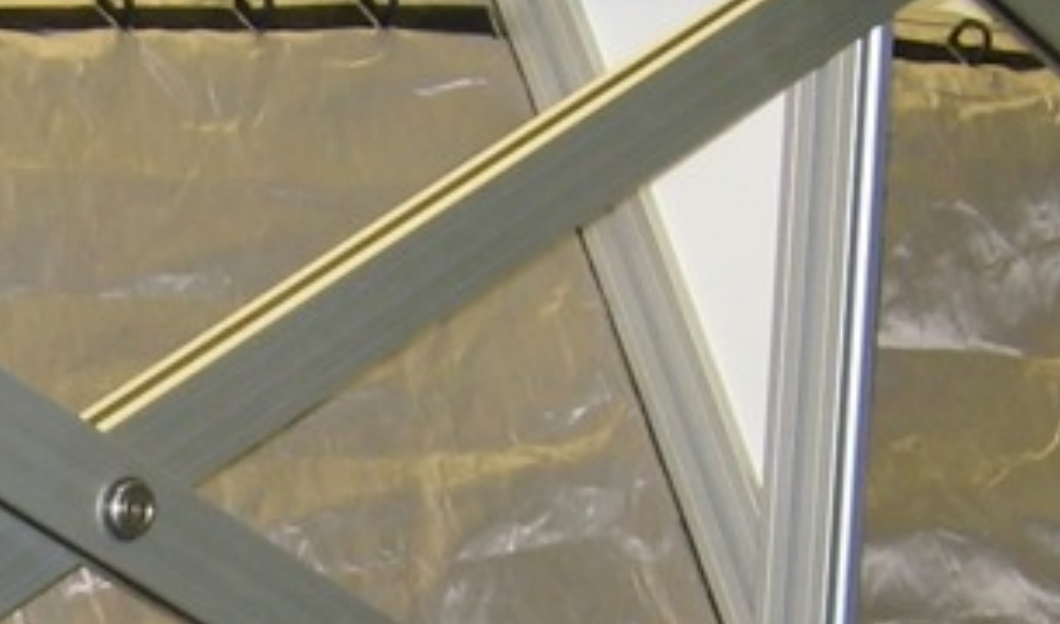


\section{SUMMARY}

Increased extent of tumor resection (EOTR) is associated with prolonged survival for glioblastoma patients. Conventional neuronavigation can be helpful in planning the surgical approach but can become unreliable during surgery due to "brain shift", which is caused by tumor resection, loss of cerebrospinal fluid and brain tissue edema. Intraoperative MRI (iMRI) has been developed to correct for brain shift during surgery, and to offer the neurosurgeon updated images for neuronavigation. This should lead to increased EOTR without causing (additional) neurological deficit. This thesis evaluates the added value of the PoleStar N20 (0.15T) iMRI system with local Faraday shielding (using a "StarShield" $($ tent) on glioblastoma surgery.

The quality of the existing literature up to 2011 was limited due to several forms of bias, as explained in chapter 2. Of these, especially attribution bias was present in many studies. The old Latin proverb "post hoc ergo propter hoc" ends with a question mark: after which, so caused by? The conclusion that iMRI scanning demonstrated residual contrast enhancement (suspect to be tumor) at the moment the neurosurgeon "would have stopped resection" otherwise, is unreliable. The opportunity for intraoperative control seems to lead to a more conservative approach regarding tumor resection, which in return "causes" at least part of the residual enhancement. This question can only be solved by a randomized controlled trial (RCT).

One of the challenges in reporting study outcome after tumor resection is to use a valid endpoint. There are many validated scales to report patient outcome. In contrast, technical outcome of neurosurgical treament is often expressed in residual tumor volume or resection percentage, which has not been validated yet. In chapter 3 we report the results for intraobserver and interobserver agreement for tumor volumetry (focused on glioblastoma). Both preoperative and postoperative tumor volumetry have high intraobserver agreement. But in contrast to preoperative tumor volumetry, postoperative tumor volumetry has low interobserver agreement. Therefore, residual tumor volume cannot be reliably estimated. Still, if one observer is performing the measurements, a comparison between two groups can be made to demonstrate a trend in the data. Absolute numbers on performed or desirable EOTR cannot be provided yet, as a valid method for measurement is lacking. This is a serious limitation for comparative studies and for other studies that aim to describe a minimally required EOTR to improve survival. 
Furthermore, in chapter 4 we report a study that examined the correlation between intraoperative contrast enhancement and histopathology. latrogenic damage to the blood-brain barrier during surgery might influence the contrast enhancement pattern of glioblastoma, compared to the preoperative situation. Intraoperative contrast enhancement has not systematically been examined to what extent it correlates to tumor presence. Still, this is considered as the gold standard during glioblastoma surgery. In our Borderzone Sampling trial we could quantify the correlation between contrast enhancement on $\mathrm{MRI}$ and glioblastoma presence on histology. Clear contrast enhancement does correlate with tumor presence, but absence of contrast enhancement does not correlate with absence of tumor tissue in circa $50 \%$ of the cases.

Up to date, two RCT's on glioblastoma surgery have been performed using ultra low-field strength iMRI: one by Senft et al. (2011), and the study by our group (2013) which is reported in chapter 5. The Senft study is considered as class I evidence that iMRI-guided resection of glioblastoma leads to an increased percentage of gross total resection compared to conventional navigation-guided resection (96\% versus 68\% respectively). Critical in this context is the definition of gross total resection, which was defined as "less than $0.175 \mathrm{~cm}^{3}$ residual contrast enhancement". Comparing secondary study endpoints of the Senft trial, the results are less convincing: median residual tumor volume in the iMRI-group was $0.00 \mathrm{~cm}^{3}$ whereas median residual tumor volume in the control group was $0.03 \mathrm{~cm}^{3}$. Also 6 months progression-free survival did not differ between both groups. In our study we could not demonstrate any statistically significant difference between the iMRI group and the control group using conventional neuronavigation with respect to EOTR, clinical performance or survival.

The results of these RCTs should be seen in the light of two complicating factors: the absence of a valid method for postoperative tumor volumetry, and the limited correlation between contrast enhancement on iMRI and tumor presence on histology.

Therefore, we consider (ultra) low-field strength iMRI-guided glioblastoma surgery not to be significantly more effective than standard treatment. The previously published literature has too many quality flaws to demonstrate the added value, EOTR cannot yet be measured in a reliable manner, imaging-based tumor definition is still troublesome with limited correlation between iMRI contrast enhancement and histology, and health-related quality of life does not show a trend towards a relevant difference. 
For now, neither ultra low-field strength iMRI nor a minimally required 98\% EOTR should be considered as a gold standard for glioblastoma surgery. For the future we need to develop a clear definition on what to consider as glioblastoma based on imaging characteristics and a valid method to measure EOTR in order to evaluate to what extent EOTR has added value in patient treatment. All this should be seen in the context of a surgically incurable disease, for which the principle "primum non nocere" (first do not harm) is as old as it is wise. 


\section{SAMENVATTING}

Een toegenomen mate van tumorresectie (MVTR) wordt in verband gebracht met een langere overleving voor patiënten met een glioblastoom. Standaard neuronavigatie kan helpen bij het planning van de operatieve benadering, maar kan tijdens een operatie onnauwkeurig worden ten gevolge van "hersenverplaatsing" veroorzaakt door tumorresectie, verlies van hersenvocht, en zwelling. Intraoperatieve MRI (iMRI) is ontwikkeld om tijdens de operatie te corrigeren voor deze hersenverplaatsing, en om de neurochirurg actuele beelden te geven voor neuronavigatie. Dit beoogt te zorgen voor een toegenomen MVTR zonder toegenomen neurologische uitval. Dit proefschrift onderzoekt de toegevoegde waarde van de PoleStar N20, een 0.15 Tesla iMRI systeem met lokale Faraday-kooi (in de vorm van de Starshield $®$ tent) bij glioblastoomchirurgie.

De kwaliteit van de bestaande literatuur tot 2011 was beperkt ten gevolge van verschillende soorten vertekening (bias), zoals uitgelegd in hoofdstuk 2. Van deze vormen van vertekening, met name zogeheten "attributie-bias" was aanwezig in veel studies. Het oud Latijns gezegde "post hoc ergo propter hoc" eindigt met een vraagteken: erna, dus erdoor? De conclusie dat iMRI scans restaankleuring toonden (verdacht voor tumorrest) op het moment dat de neurochirurg aangaf anders "gestopt te zijn met de operatie" is onbetrouwbaar. De mogelijkheid om tijdens de operatie te kunnen controleren of restaankleuring aanwezig was, lijkt te leiden tot een meer terughoudende benadering aangaande tumorresectie. Dit kan (een deel van) deze restaankleuring verklaren. Dit probleem kan alleen opgelost worden middels een gerandomiseerde studie.

Een van de uitdagingen in het rapporteren van studie-uitkomsten na tumorresectie is het gebruik van een valide uitkomstmaat. Er zijn veel gevalideerde schalen beschikbaar om het functioneren van patiënten na een behandeling te meten. Echter als uitkomstmaat voor een technische handeling zoals een tumorresectie wordt vaak resttumorvolume of resectiepercentage gebruikt. Hiervoor is geen valide uitkomstmaat beschikbaar. In hoofdstuk 3 rapporteren wij de resultaten aangaande intrabeoordelaar en interbeoordelaar overeenstemming voor tumor volumetrie (gericht op het glioblastoom). Zowel preoperatieve als postoperatieve tumorvolumetrie hebben hoge intraobserver overeenstemming. Echter in tegenstelling tot preoperatieve volumetrie heeft postoperatieve volumetrie een lage interobserver overeenstemming. Daarom kan resttumorvolume niet betrouwbaar beoordeeld worden. Op dit ogenblik is het wel mogelijk om een trend in de meetwaarden aan te tonen, maar niet om harde getallen te geven aangaande een verrichte danwel gewenste MVTR. Dit is een forse 
beperking voor vergelijkende studies en voor studies die beogen een minimaal vereiste MVTR te beschrijven die moet leiden tot een betere overleving.

In hoofdstuk 4 rapporteren we een studie die de relatie beschrijft tussen intraoperatieve contrastaankleuring en histopathologie. latrogene schade aan de bloed-hersenbarrière tijdens operatie kan het aankleuringspatroon van het glioblastoom beïnvloeden, in vergelijking met de preoperatieve situatie. Er is nooit systematisch onderzoek in welke mate intraoperatieve contrastaankleuring overeenkomt met aanwezigheid van tumor. Nochtans wordt dit wel beschouwd als gouden standaard tijdens glioblastoomchirurgie. In onze Borderzone Sampling studie konden we een kwantitatief verband leggen tussen contrastaankleuring op iMRI en histopathologische aanwezigheid van | glioblastoom. Duidelijke contrastaankleuring komt overeen met aanwezigheid van tumor, echter afwezigheid van contrastaankleuring correleert niet met afwezigheid van tumor in circa $50 \%$ van de gevallen.

Tot op heden zijn er twee gerandomiseerde studies verricht binnen de glioblastoomchirurgie die gebruik maken van ultra lage-veldsterkte iMRI: een door Senft et al. (2011) en onze studie (2013) die beschreven staat in hoofdstuk 5. De Senft-studie wordt beschouwd als klasse 1 bewijs dat iMRIgeleide resectie van het glioblastoom leidt tot een toegenomen percentage van maximale resectie in vergelijking met standaard navigatie-geleide resectie (respectievelijk 96\% en 68\%). Belangrijk in dit verband is de definitie van "maximale resectie", namelijk minder dan $0.175 \mathrm{~cm}^{3}$ restaankleuring. De overige uitkomstmaten van de Senft-studie zijn niet overtuigend: mediaan resttumorvolume in de iMRI groep bedroeg $0.00 \mathrm{~cm}^{3}$ terwijl mediaan resttumorvolume in de controlegroep $0.03 \mathrm{~cm}^{3}$ bedroeg. Progressie-vrije overleving na 6 maanden verschilde niet tussen beide groepen. In onze studie konden we geen statistisch significant verschil aantonen tussen de iMRI groep en de controlegroep (standaard neuronavigatie) met betrekking tot MVTR, klinisch functioneren van de patiënten of overleving.

De resultaten van deze gerandomiseerde studies moeten gezien worden in het licht van twee complicerende factoren: de afwezigheid van een valide manier om postoperatief tumorvolume te meten, en de beperkte relatie tussen contrastaankleuring op iMRI en histopathologische aanwezigheid van tumor.

Om deze redenen beschouwen wij (ultra) lage-veldsterkte iMRI-geleide resectie van het glioblastoom niet als bewezen effectiever dan de standaardbehandeling. De voordien gepubliceerde literatuur 
kent teveel methodologische beperkingen om de toegevoegde waarde aan te tonen, MVTR kan niet betrouwbaar gemeten worden, de definitie van tumor op basis van beeldvorming is onvoldoende duidelijk met een beperkte relatie tussen contrastaankleuring en histopathologie, en gezondheidsgerelateerde kwaliteit van leven toont geen duidelijke trend richting een relevant verschil.

Voor nu, noch ultra lage-veldsterkte iMRI noch een minimaal vereiste 98\% MVTR dienen beschouwd te worden als een gouden standaard voor glioblastoomchirurgie. Voor de toekomst moeten we een duidelijke definitie ontwikkelen van wat te beschouwen als tumor op basis van beeldvorming en een valide manier om MVTR te meten, om te kunnen beoordelen in welke mate MVTR toegevoegde waarde heeft in de behandeling van patiënten met een glioblastoom. Al dit moet gezien worden in de context van een chirurgisch niet te genezen ziekte, waarbij het principe "primum non nocere" (in de eerste plaats, doe geen kwaad) even oud is als wijs. 


\section{ACKNOWLEDGMENTS}

This thesis has been completed due to the help of many people, in the first place the patients and their family members that participated in the studies we performed.

Besides I wish to express my gratitude towards my colleagues for all their help, and to my family for their loving support. As almost all of them are Dutch the next section gives many of them a personal thanks in their native language. 


\section{AAN IEDEREEN, MET NAME...}

Dit proefschrift is tot stand gekomen door de bijdragen van veel verschillende mensen, direct danwel indirect. Een aantal van hen wil ik met name bedanken, vanwege hun concrete bijdragen en hun inspirerende aanwezigheid.

Hoewel mijn onderzoek technologisch van aard is, staat de techniek in dienst van de arts en uiteindelijk de patiënt. Aan de deelnemers en familie van de Borderzone Sampling studie en de gerandomiseerde studie ben ik dan ook zeer veel dank verschuldigd voor het gestelde vertrouwen, en de medewerking aan de studies.

Prof.dr. J.J. van Overbeeke, beste Koo, onder jouw supervisie heb ik zowel mijn promotie-onderzoek als opleiding tot neurochirurg voltooid. In beide ervaar ik jouw "walk your talk" gehalte als een groot voorbeeld, en ben je me met raad en daad tot steun geweest. Voorts ben ik via jou in contact gekomen met een van je eigen opleiders, professor James Ausman, waar ik ook veel aan te danken heb. Wat betreft de technologische kant van mijn eigen carrière ben ik je op het juiste moment tegengekomen. Je kritische vragen hebben me geholpen mijn focus helder te krijgen, en daar heb ik vervolgens de vruchten van mogen plukken.

Dr. H. van Santbrink, beste Henk, in je eigen proefschrift beschrijf je een haat-liefdeverhouding te hebben gehad met jouw copromotor. Die ervaring deel ik absoluut niet. Weliswaar hoor ik innerlijk jouw stem "punt" zeggen als ik na vier regels tekst de achtste komma toevoeg om een zoveelste bijzin te produceren, en die punt is dan hard nodig. Verder herinner ik me onze samenwerking vooral als gemoedelijk, gaandeweg kameraadschappelijk, waarbij je me op cruciale momenten op de juiste manier wist te motiveren om datgene te doen wat nodig was. Ik ben dankbaar voor je begeleiding als opleider en copromotor, maar meer nog voor je begeleiding als mens.

Prof.dr. E.A.M. Beuls, onder uw begeleiding heb ik mijn eerste stappen gezet in de neurochirurgie. Ik herinner mij als gisteren mijn sollicitatiegesprek, waarin $u$ tegen de aanwezige (toen nog geheten) drs. Vandewalle sprak: "Dit is Pieter, die weet veel van computers en zo iemand hebben wij nodig". Dank voor het vertrouwen waarmee $u$ mij een opleidingsplaats tot neurochirurg hebt aangeboden. 
Uw motto was altijd "Ge moet de mogelijkheden zien" en dat motto heb ik met genoegen overgenomen in mijn eigen ontwikkeling.

Dr. G.H.J.J. Spincemaille, beste Geert, samen met professor Beuls heb jij ervoor gezorgd dat het academisch ziekenhuis in Maastricht als eerste (en tot nu toe enige) ziekenhuis in het land de beschikking kreeg over een intraoperatieve MRI. Onder jouw begeleiding heb ik niet alleen kunnen starten met mijn promotie-onderzoek, maar ook de samenwerking met de Technische Universiteit Eindhoven (TU/e) kunnen uitbouwen, alsmede de samenwerking met Medtronic Navigation. Je eigen proefschrift sloot je af met de woorden: "De toekomst is aan hen die durven", en ook dat motto heb ik graag overgenomen.

Prof.dr.ir. B. ter Haar Romeny, beste Bart, dank voor de prettige samenwerking met de afdeling Biomedical Image Analysis (BMIA) van de TU/e. Het was voor mij een nieuwe wereld, waar je me snel in hebt laten thuis voelen. Het was een verrijking om de wetenschap mee te beleven door technische ogen, en soms een uitdaging om de aansluiting bij het klinisch denken te laten ontstaan. Ik kijk terug op een leuke en leerzame tijd, en wens jou en je vrouw het allerbeste voor je emeritaat, en bovenal een goede gezondheid!

Bram Platel, ik heb veel plezier beleefd aan onze samenwerking in de BMIA context. Of het gesprek nu ging over non-linear image transformations (op een Mac, uiteraard) of het unlocken van de eerste iPhone: als Apple adepten begrepen wij elkaar uitstekend! Het UMCN mag zich gelukkig prijzen met jou als aanvulling...

MSc en PhD studenten van de BMIA groep (Ralph, Ellen, Joost, Annet), dank voor de leuke samenwerking. Jullie hebben me versteld doen staan van wat jullie in een korte periode kunnen bereiken, onder begeleiding van Bart, Bram, en Anna Vilanova, en ik hoop in de toekomst een soortgelijke samenwerking opnieuw te mogen beleven.

Erwin Cornips, al vroegtijdig heb jij de iMRI in Maastricht omarmd als hulpmiddel voor de hypofysechirurgie, en kinderoncologie. Dat heeft een waardevolle bijdrage geleverd aan de kennis en ervaring die we met het apparaat hebben opgedaan, en geleid tot meerdere gezamenlijke artikelen. En congresbijdragen... onder de Eiffeltoren kon ik je rennend nog bijhouden, tegenwoordig loop je kilometertijden waar ik alleen jaloers op kan zijn. 
Olaf Schijns en Mariël ter Laak-Poort, jullie hebben het merendeel van de iMRI-geleide operaties uitgevoerd waarbij ik zowel beter heb leren opereren, als ook de data voor mijn onderzoek kon verzamelen. Dit alles in een prettige en ontspannen sfeer, ook als de opstartprocedure voor de ingreep weer eens langer nodig had dan verwacht in verband met een technisch probleem. Dank jullie wel!

Onno Teernstra, dank je dat je in Heerlen onderzoekscoördinator hebt willen zijn voor de RACING studie. Je whiteboard stond toen al vol met studies waaraan je deelnam, ik ben blij dat deze er nog bij mocht. Een tip voor als dat whiteboard nog voller wordt: je kunt er nog eentje aan het plafond van je kamer hangen. Proefondervindelijk hebben we reeds gezien dat andere voorwerpen daar ook aan blijven kleven.

Professeur Martin, cher Didier, nous nous sommes rencontrés pendant une conférence de Medtronic, et il n'y a pas beaucoup des personnes qui savent que la collaboration entre Maastricht et Liège a commencé avec nous deux qui ont dansé le flamengo (heureusement il y avait des autres personnes aussi à cette soirée organisé par Medtronic). Tu m'as expliqué qu'on ne subit pas un opération, mais on bénéficie d'un opération (mais qu'au contraire, on subit une coloscopie, tu as dit). Je te remercie pour l'atmosphère toujours amicale quand je venais à Liège en salle d'opération pour la recherche. Merci beaucoup!

Dr. Scholtes, cher Felix, notre collaboration est vraiment amicale, tu es plus un ami qu'un collègue. Ensemble, nous avons réussi à concrétiser l'étude randomisée de commencer, et je suis heureux que tu aies décidé de travailler à Liège aussi après ta formation. J'espère que notre collaboration peut continuer pour d'autres recherches dans l'avenir!

Alle andere stafleden neurochirurgie van onze vakgroep, dank dat jullie aan mij en mijn studies dachten wanneer jullie een patiënt met een (vermoedelijk) glioblastoom gepresenteerd kregen, en een operatie overwogen. En -buiten mijn onderzoek om- bovenal dank voor jullie bijdragen aan mijn opleiding tot neurochirurg en collegiale houding.

Pieter Wesseling en Martin Lammens, jullie hebben een grote bijdrage geleverd aan de Borderzone Sampling studie. Na een kenninsmakingsgesprek was jullie duidelijk dat een gestandaardiseerde manier van dataverzameling nodig was. Jullie hebben dit zelf opgezet en uitgevoerd, waarvoor grote dank. 
Linda Jacobi, je weet inmiddels wat tumor-volumetrie inhoudt. En met name de hoeveelheid tijd die daarmee gemoeid is. Dank je dat je die toch hebt willen vrijmaken, het heeft een grote meerwaarde gehad voor mijn onderzoek.

Collega arts-assistenten en Luc, dank voor de leuke sfeer en onderlinge collegialiteit, als ook de ruimte om voor mijn onderzoek de intraoperatieve MRI-operaties te kunnen bijwonen. Het voelt als een voorrecht om te werken binnen een groep die elkaar onderling steunt, en waar altijd flexibel gekeken wordt naar mogelijkheden in plaats van onmogelijkheden.

Neuro-oncologieverpleegkundigen, Hilly en Natasja, dank voor de hulp met het completeren van de data!

Medewerkers van de operatiekamer, jullie hebben mijn onderzoek mede mogelijk gemaakt. De introductie van "dat ding" ging zeker niet zonder problemen, en mede dankzij jullie open houding hebben we onze kennis kunnen uitbouwen, en dit onderzoek kunnen verrichten.

Planners van de operatiekamer, jullie zijn ons immer terwille geweest als er weer een deelnemer aan een van onze studies was waarvoor intraoperatieve MRI nodig was. Neurooncologie kent geen electief karakter, en ons onderzoek nam extra OK-tijd in beslag. Dank dat jullie deze ruimte herhaaldelijk voor ons gecreëerd hebben.

Poetsploeg van de operatiekamer, jullie bijdrage aan dit onderzoek is makkelijk te onderschatten. We ontdekten al snel dat onze local Faraday shielding erg gevoelig was voor ruis, en dat goed contact met de vloerplaat essentieel was. Dat deze een speciale voorbehandeling vereist, hebben we gaandeweg ondervonden. Dat er aparte borden "plaat poetsen" op OK 15 bestonden, onderstreept dit belang. Dank jullie voor alle hulp!

Medtronic Navigation staff, in particular Serge, Zvi, Hans, Jacob and Jan, thanks for your help throughout the years, the unrestricted grants with which you have supported our research, and the user meetings which have been both informative and enjoyable. 
Martien Limburg, je sloot mijn stagejaar neurologie af met de conclusie dat ik een "hoog associatief denkpatroon" heb. Er heeft me nog nooit iemand zo constructief uitgelegd dat ik (soms) van de hak op de tak kan springen en onnavolgbaar ben. Je hebt me leren focussen op de andere kant van de medaille, waarvoor grote dank. En mindmaps gebruik ik nog steeds!

Wim Weber, hoewel we elkaar niet meer vaak tegenkomen, moet ik toch vaak terugdenken aan je kledingadviezen tijdens mijn stagejaar neurologie. Als ik straks mijn proefschrift verdedig, en aantreed met kraag, donkere sokken en gepoetste schoenen, zal ik denken: zo zou Pim Wim het gewild hebben...

Fons Kessels, professor Don Alfonso, dank voor je humor, en zeker ook dank voor je geduld. Ik realiseer me dat je het in het begin nodig hebt gehad! Ik ben blij dat je ook na je pensionering nog wat tijd wilde vrijmaken om me te helpen met het afronden van dit boekje.

Rob en Hannie, als ik mijn schoonouders zelf had mogen uitzoeken, had ik jullie ook gekozen. Dank jullie voor het tweede thuis, de warmte en liefde, de geborgenheid. Ik hoop nog veel mooie momenten met jullie te beleven!

Rick, Christel, Tim en Roslynn, het voelt goed om jullie als schoonbroers en -zussen te hebben. Of het nu gaat om het volgen van een huwelijksdag via WhatsApp danwel twee beschaafde mensen in onze woonkamer te zien veranderen in holbewoners, alles kan... Dank!

Nard, je bent mijn enig(st)e broer, en een mens waar ik veel respect voor heb. Ik kijk met een glimlach terug op de jaren waarin we gezamenlijk zijn opgegroeid, en waarin jouw wetenschappelijk inzicht het mijne reeds overtrof: een emmer blijkt veel sneller gevuld te zijn met bessen, als je eerst op de bodem een dikke laag blaadjes legt! Op de middelbare school had je er wel eens moeite mee om "de broer van" te zijn, en begrijpelijk. Nu ben ik "de broer van". Je bent me voorgegaan met jouw promotie-onderzoek, dat dermate veel voor mij onbegrijpelijke terminologie bevat dat ik het anderen nog steeds uitleg als "iets met eiwitten en veroudering". Lamines, leg je die niet op de vloer in je woonkamer? Sta me toe jou mijn onderzoek kort uit te leggen in de terminologie waarmee jij mijn vak beschrijt: je neemt een pleister (de operatie) en plakt die op de wond (het glioblastoma). De vraag is of de pleister beter werkt als je een foto maakt tijdens het plakken, dan wanneer je dat alleen tevoren doet. Capice? 
Pap, zonder jou had ik niet gestaan waar ik nu sta. Sterker nog, zonder jou had ik helemaal nergens gestaan (...). Je hebt me de ruimte gegeven voor mijn toekomstkeuzen, en de ruimte gegeven om me computers eigen te maken op een manier waar ik veel voordeel van heb ondervonden. Tegelijk was er de ruimte buiten, een ruimte die ik nog steeds erg waardeer. De laatste jaren ontdek ik steeds meer in welke mate we op elkaar lijken, en kan ik het liedje van Stef Bos niet meer horen zonder licht glinsterende ogen te krijgen. Papa, ik hou steeds meer van jou...

Mam, je bent altijd de steunpilaar in het gezin geweest, je hebt er als moeder altijd gestaan voor Nard en mij. Je was er voor ons als het goed ging, en je was er voor ons als het niet goed ging. Je was er eigenlijk altijd voor ons, als we je nodig hadden. Je hebt ons gesteund om te groeien in datgene wat we goed konden, en je hebt ons geholpen om te groeien in datgene wat we niet goed konden. Je hebt ons getoond wat onvoorwaardelijke liefde is. Ik hou van jou, en hoewel ik de boodschap van het liedje "Blief bie de mam" op mijn eigen manier wil invullen, vind ik de afsluiting van het nummer eenvoudigweg prachtig krachtig... Mama, bedankt!

Mandy, jij bent de reden waarom ik in liefde geloof. Je houdt me in balans, je hebt me laten groeien als mens, en je hebt me meer rust in mijn leven gegeven. Bij jou kan ik mezelf zijn, en mijn eigen accu opladen. Ik ben blij met je steun, en heel dankbaar voor je liefde. Ik hou veel van je, en wil graag met jou oud worden. From this moment on... 


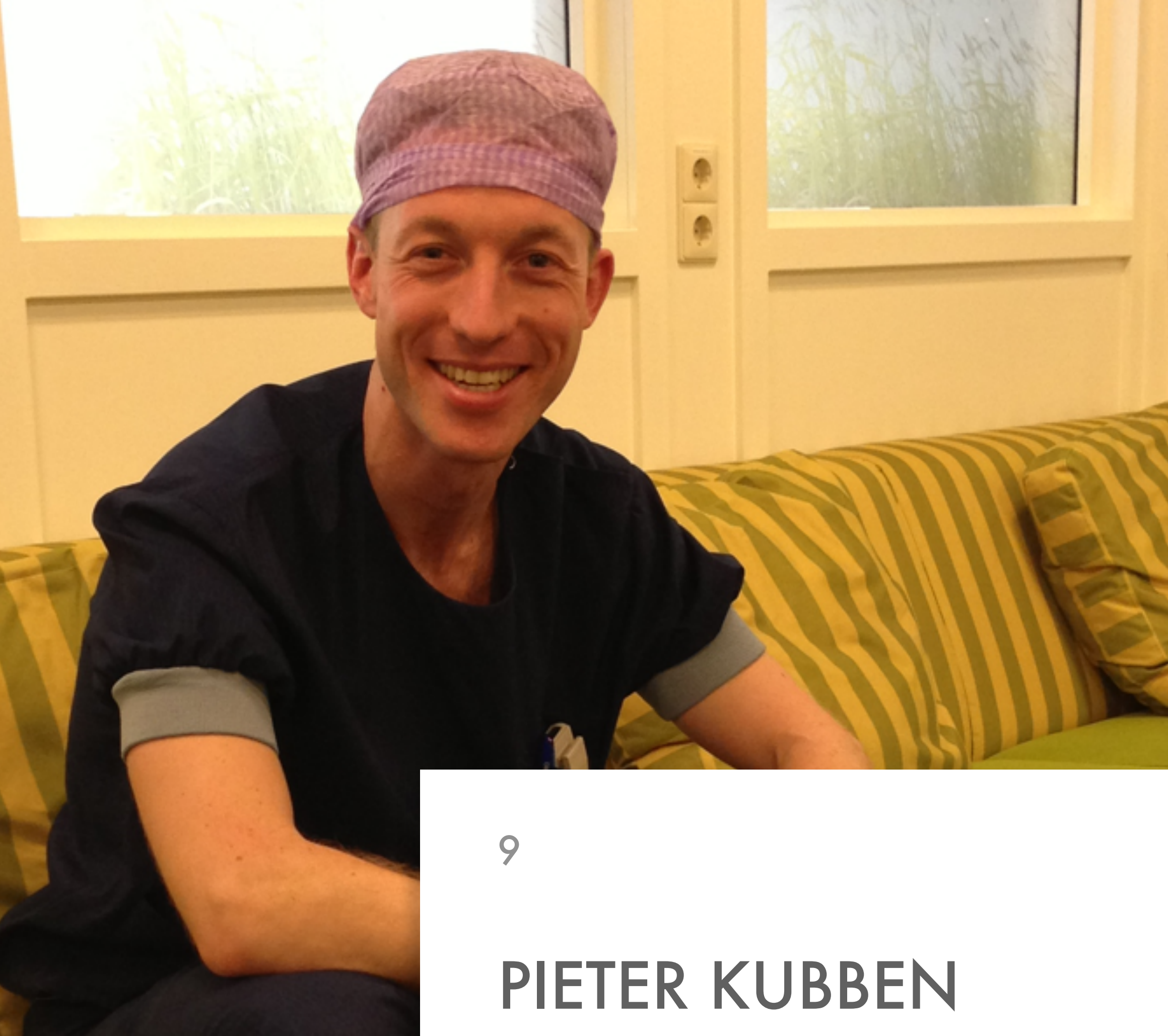




\section{CURRICULUM VITAE}

\section{Nederlands}

Pieter Kubben is geboren op zondag 30 april 1978 in Geleen. De peuterjaren werden doorgebracht in Moorveld. Nadien verhuisde het gezin naar Munstergeleen, alwaar de eerste schooljaren doorgebracht werden bij basisschool Aon de Bronkboum. De schoolcarrière werd vanaf 1990 vervolgd aan het gymnasium bij scholengemeenschap Sint Michiel te Geleen, met een beta-richting in de laatste twee schooljaren. $\mathrm{Na}$ een gunstige loting werd in 1996 gestart met de studie geneeskunde aan de Universiteit Maastricht. Al in het tweede studiejaar bleek de interesse voor neurowetenschappen, welke versterkt werd door een tweetal keuzeblokken in die richting. Deze leidden tot de eeste stapjes op wetenschappelijk terrein, zowel bij de neurologie (met dr. A. Twijnstra) als bij de neurochirurgie (met drs. E. Kurt en dr. M. van Kroonenburgh). Tijdens de co-schappen werd de voorkeur voor een verdere carrière duidelijk: neurochirurgie. Na een positief kennismakings- en sollicitatiegesprek met prof.dr. E. Beuls en (toen nog) drs. Vandewalle startte de ANIOS periode in 2003. Vanaf 2006 werd dit omgezet in een AGIKO-constructie in samenwerking met de technische universiteit Eindhoven, met onderzoeksbegeleiding van dr. G. Spincemaille en nadien dr. H. van Santbrink. Vanaf 2008 werd het klinisch opleiderschap overgenomen door prof.dr. J. van Overbeeke voor Maastricht en dr. H. van Santbrink voor Heerlen. Gedurende dezelfde periode werd het overige ICT-aandachtsgebied uitgebouwd, eerst in samenwerking met prof.dr. A. Scherpbier en dr. H. Hoogland, nadien in samenwerking met prof.dr. J. Ausman (Surgical Neurology International). In 2012 volgde een onderzoeksstage naar Brain Computer Interfaces aan de UCLA (Los Angeles, California) in samenwerking met dr. N. Pouratian. Vanaf 1 januari 2014 is Pieter zich als neurochirurg in het MUMC+ verder aan het verdiepen in de functionele neurochirurgie, en daarnaast levert hij een structurele bijdrage aan de informatietechnologie in het ziekenhuis.

\section{English}

A detailed and up-to-date curriculum vitae is available online. 


\section{ARTICLES}

Schols AMR, Donkers HHLM, Voorend M, Verstegen DML, Hoogland H, Kubben PL. The Use of Smartphones and Mobile Clinical Decision Support Systems in Clinical Clerkships. International Journal of Interactive Mobile Technologies. 2013 Apr;7(2):80-4.

Kubben PL, van Santbrink H. Intraoperative magnetic resonance imaging for high grade glioma resection: Evidence-based or wishful thinking? Surg Neurol Int. 2013;4:1.

Kubben PL, van Santbrink H, Laak-Poort ter M, Weber JW, Vles JSH, Granzen B, et al. Implementation of a mobile 0.15-T intraoperative MR system in pediatric neuro-oncological surgery: feasibility and correlation with early postoperative high-field strength MRI. Childs Nerv Syst. 2012 Aug;28(8):1171-80.

Kubben P, van Santbrink H. Glioblastoma resection. J Neurosurg. 2012 May;116(5):1163-4-author reply1167-8.

Kubben P, Pouratian N. An open-source and cross-platform framework for Brain Computer Interfaceguided robotic arm control. Surg Neurol Int. 2012;3(1):149.

Pereira JLB, Kubben PL, de Albuquerque LAF, de Carvalho GTC, de Sousa AA. Blogs for neurosurgeons. Surg Neurol Int. 2012;3:62.

Kubben P, Wesseling P, Lammens M, Schijns OMG, Laak Poort ter M, van Overbeeke J, et al. Correlation between contrast enhancement on intraoperative magnetic resonance imaging and histopathology in glioblastoma. Surg Neurol Int. 2012;3(1):158. 
Kubben PL, van Santbrink H. [Intraoperatieve MRI-geleide resectie van het glioblastoma multiforme]. Oncologie Up-to-date. 2012;3(1):12.

Kubben PL, Meulen Ter KJ, Schijns OE, Laak-Poort Ter MP, van Overbeeke JJ, van Santbrink H. Intraoperative MRI-guided resection of glioblastoma multiforme: a systematic review. The Lancet Oncology. 2011 Aug 23;12(11):1062-70.

Kubben PL, van Santbrink H, Cornips EMJ, Vaccaro AR, Dvorak MF, van Rhijn LW, et al. An evidencebased mobile decision support system for subaxial cervical spine injury treatment. Surg Neurol Int. 2011;2:32.

Kubben PL, Postma AA, Kessels AGH, van Overbeeke JJ, van Santbrink H. Intraobserver and interobserver agreement in volumetric assessment of glioblastoma multiforme resection. Neurosurgery. 2010 Nov;67(5):1329-34.

Kubben PL, Cornips EMJ, Looij B-J, Beuls EAM. Transsphenoidal treatment of secondary empty sella syndrome using low field strength intraoperative MRI: case report. Minim Invasive Neurosurg. 2010 Aug;53(4):198-202.

Kubben PL. A collaborative webbased framework with optimized mobile synchronisation: Upgrading to Medicine 2.0. International Journal of Interactive Mobile Technologies. 2008 Jul;2(3).

Kubben PL, van Santbrink H, Spincemaille GHJJ, Vandertop WP. [Intraoperative MRI in brain surgery]. Nederlands tijdschrift voor geneeskunde. 2007 Dec 29;151(52):2877-82.

Kubben PL, Spincemaille GHJJ. [Intraoperatieve MRI: technische overkill of een stap in de richting van 'computer assisted surgery' (CAS) en robotisering?]. Tijdschr Neurol Neurochir 2006;107:182-7. 


\section{EDITORIALS}

Kubben PL. Why physicians might want to learn computer programming. Surg Neurol Int. 2013;4:30.

Kubben PL. Windows 8: A promise for tablet computers in the hospital? Surg Neurol Int. 2013;4:11.

Kubben PL. Online conferencing: Less CO2, more effective? Surg Neurol Int. 2012;3:115.

Kubben P. NeuroMind 2: Interactive decision support for neurosurgery. Surg Neurol Int. 2012;3:109.

Kubben PL. SLIC 2: Improved decision support for subaxial cervical spine injury. Surg Neurol Int. 2012;3:30.

Kubben PL. Twitter for neurosurgeons. Surg Neurol Int. 2011;2:28.

Kubben PL. QR codes in neurosurgery. Surg Neurol Int. 2011;2:104.

Kubben PL. Neurosurgical apps for iPhone, iPod Touch, iPad and Android. Surg Neurol Int. 2010;1:89.

Kubben PL. Neurosurgical videos going mobile. Surg Neurol Int. 2010;1:67.

Kubben PL. Neurosurgical content for mobile devices. Surg Neurol Int. 2010;1:46. 
Kubben PL. What every neurosurgeon should know about the Web 2.0. Surg Neurol Int. 2010;1.

Kubben PL. Introducing neurosurgery 2.0. Surg Neurol Int. 2010;1:8. 


\section{ABSTRACTS}

"Scherpe tumorranden (?)". Kubben P. 3e Publieksdag Hersentumoren. Maarssen, NL. 16 March 2013.

"Brain-computer interfaces voor robotarmen: een systematische review". Kubben P, Hauptman J, Pouratian N. Wintermeeting NVvN. Utrecht, NL. 25 January 2013.

"Low-field strength intraoperative MRI-guided resection of glioblastoma multiforme: evidence-based?" Kubben PL. 3rd Belgian-Dutch neurosurgery meeting days. Spa-Balmoral, Belgium. 12-13 Oct 2012.

"Intraoperatieve MRI-geleide resectie van het glioblastoma". Kubben PL, Ter Meulen KJ, Schijns OEMG, Ter Laak-Poort M, Van Overbeeke JJ, Van Santbrink H. Neuro-Intercity, NL. 19 Sep 2012.

Invited lecture on intraoperative MRI at the 10th EANO conference. "Intraoperative MRI guided resection of glioblastoma multiforme" Kubben PL, Ter Meulen KJ, Schijns OEMG, Ter Laak - Poort MP, Van Overbeeke JJ, Van Santbrink H. Marseille, France. 6 - 9 September 2012.

"Mobile clinical decision support systems for implementation of neurooncological guidelines" Kubben PL. 10th EANO conference. Marseille, France. 6 - 9 September 2012.

"MDE Support for Process-Oriented Health Information Systems: from Theory to Practice" Van Gorp P, Vanderfeesten I, Dalinghaus W, Mengerink J, Van der Sanden B, Kubben P. FHIES 2012. Paris, France. 27-28 August 2012. 
"Intraoperative MRI guided resection of glioblastoma multiforme" Kubben PL, Ter Meulen KJ, Schijns OEMG, Ter Laak - Poort MP, Van Overbeeke JJ, Van Santbrink H. NVvN voorjaarsmeeting. Garderen, The Netherlands. 11 May 2012.

"De relatie tussen contrastaankleuring op intraoperatieve MRI en histopathologie bij het glioblastoma multiforme." Kubben PL, Wesseling P, Schijns OEMG, Ter Laak - Poort MP, Van Santbrink H. Meeting of the Dutch Working Group for Neuro-Oncology. Rotterdam, The Netherlands. 7 October 2011.

"Gebruik van Smartphones tijdens de Co-schappen." Donkers J, Kubben P, Schols A, Verstegen D, Hoogland H. Onderwijs Research Dagen. Maastricht, The Netherlands. 8-10 June 2011.

"De digitale neurochirurg: perspectieven voor nu en de toekomst." Kubben PL. NANCHO-V. Utrecht, The Netherlands. 11 March 2011.

"De relatie tussen contrastaankleuring op intraoperatieve MRI en histopathologie bij het glioblastoma multiforme." Kubben PL, Wesseling P, Schijns OEMG, Ter Laak - Poort MP, Van Santbrink H. Wintermeeting NVvN. 28 January 2011.

"Intraoperatieve MRI-geleide resectie van het glioblastoma multiforme: een systematische review." Kubben PL, Ter Meulen KJ, Schijns OEMG, Ter Laak - Poort MP, Van Overbeeke JJ, Van Santbrink H. Wintermeeting NVvN. 28 January 2011.

"The correlation between contrast enhancement on intraoperative MRI and histopathological tumor characteristics." Kubben PL, Wesseling P, Schijns OEMG, Ter Laak - Poort MP, Van Santbrink H. 3rd Meeting of the Intraoperative Imaging Society. Zurich, Switzerland. 16-19 January 2011.

"Implementation of a mobile 0.15T intraoperative MRI in pediatric neuro-oncology: feasibility and correlation with early postoperative high-field strength MRI." Kubben PL, Van Santbrink H, Ter Laak Poort MP, Cornips EMJ. 3rd Meeting of the Intraoperative Imaging Society. Zurich, Switzerland. 16-19 January 2011. 
"Neurosurgery 2.0 - a Combination Of Open Access, Web 2.0 And Decision Technology". Kubben PL, Hoogland H, Cook J, Scherpbier AJJA, Ausman JI. Medicine 2.0 congress. Maastricht, The Netherlands. 29-30 November 2010.

"Porting a Clinical Mobile Device Application from iPhone to Android Using Online Collaboration: a Case Study Using NeuroMind". Lau JC, Kubben PL. Medicine 2.0 congress. Maastricht, The Netherlands. 29-30 November 2010.

"Intraobserver And Interobserver Agreement In Volumetric Assessment Of Glioblastoma Multiforme Resection". Kubben PL, Postma AA, Kessels AGH, Scholtes F, Martin D, Van Overbeeke JJ, Van Santbrink H. Congress of Neurological Surgeons 2010 Annual Meeting. San Francisco, CA, USA. 16-21 October 2010.

"Intraobserver en interobserver overeenstemming bij de volumetrische benadering van glioblastoma multiforme resectie". Kubben PL, Postma AA, Kessels AGH, Scholtes F, Martin D, Van Overbeeke JJ, Van Santbrink H. Meeting of the Dutch Working Group for Neuro-Oncology. Rotterdam, The Netherlands. 8 October 2010.

"Contrast enhancement on intraoperative MRI : Is it tumor?" Kubben PL, Van Santbrink H, Lammens M, Ter Laak-Poort MP, Schijns OEMG. 9th EANO congress. Maastricht, The Netherlands. 16-19 September 2010.

"Intraobserver and interobserver agreement in volumetric assessment of glioblastoma multiforme resection". Kubben PL, Postma AA, Kessels AGH, Scholtes F, Martin D, Van Overbeeke JJ, Van Santbrink H. 9th EANO congress. Maastricht, The Netherlands. 16-19 September 2010.

"Improving interobserver agreement for volumetric assessment of brain tumor resection". Kubben PL, Postma AA, Kessels AGH, Scholtes F, Martin D, Van Overbeeke JJ, Van Santbrink H. Biomedica 2010. Aachen, Germany. 17-18 March 2010. 
"Intraobserver and interobserver agreement in volumetric assessment of glioblastoma multiforme resection". Kubben PL, Postma AA, Kessels AGH, Van Santbrink H. MHeNS Research Day. Maastricht, The Netherlands. 17 March 2009.

"Preliminary experience with PoleStar N2O iMRI in pediatric neuro-oncology". Cornips E, Kubben P, Ter Laak-Poort M, Granzen B, Vles J, Weber J. 36th meeting of the International Society for Pediatric Neurosurgery (ISPN). Cape Town, South Africa. 12-16 October 2008.

"Eerste ervaringen met de PoleStar N20 intraoperatieve MRI in de kinderneurooncologie" (First experiences with the PoleStar N2O intraoperative MRI in pediatric neurooncology). Cornips E, Ter LaakPoort M, Kubben P. Najaarsvergadering NVVN, Leiden, The Netherlands. 3 October 2008.

"Combining Functional Neuronavigation and Low Field Strength Intraoperative MRI". Kubben PL. Advanced Techniques in Intraoperative MRI. Frankfurt am Main, Germany. 9-10 November 2007.

"Multimodal imaging and functional neuronavigation". Kubben PL. Advanced techniques in Image Guided Surgery. Marbella, Spain. 3-5 June 2007.

"Endoscope-based navigation and iMRI controlled resection of pituitary adenomas". Kubben PL, Cornips EMJ. 4th World Conference of the International Study Group on Neuroendoscopy. ParisVersailles, France. 9-12 May 2007.

"Combining functional neuronavigation and low field strength intraoperative MRI". Kubben PL, Spincemaille GHJJ. 1st International Symposium on Cognitive Neuroscience and Neurosurgery. Tübingen, Germany. 17-20 March 2007.

"Low field strength intraoperative MRI with functional neuronavigation using local shielding". Kubben PL, Spincemaille GHJJ. European Congress of Radiology. Vienna, Austria. 9-13 March 2007. (poster within the IMAGINE-stand of the TUe-BMT group) 
"Intramedullary spinal cord glioblastomas." Kurt E, Schijns OEMG, Kubben PL, Beuls EAM. 5th Congress of the European Association of Neuro-Oncology, Florence-Italy. 7-10 September 2002

"Evaluation of Selective Serotonin Receptors 5-HT 2A in the Brain Using 123 I-5-I-R91150 and SinglePhoton Emission Computer Tomography in Healthy Subjects." I.H.A. Al Younis, P. Kubben, H. D'Haenen, K. Van Laere, A. Honig, A. Leentjens, A. Bossuyt, M. van Kroonenburgh. Wetenschappelijke Vergadering NVNG, Zwolle. 17 mei 2002

Development and national presentation of website "e-Neurology" (an educational website with patient cases for medical students - off line in 2004). Abstract: "Effectief ontwerp van interactieve neurologische patiëntcasuïstiek voor gebruik via het web." Kubben PL, Grave WS de, Krom MCTFM de. 10e Geneeskundig Onderwijs Congres, Veldhoven. 22-23 november 2001.

"Clinical Features of 137 patients with small-cell lung cancer and a low titer of anti-Hu antibodies." Verschuuren J, Wirtz P, De Koning P, Van den Maagdenberg A, Kubben P, Ten Velde G, Twijnstra A. Abstracts of the 53rd Annual Meeting of the American Academy of Neurology, Philadelphia-USA. 511 May 2001. Neurology 2001;56(8)(suppl. 3): A415: P06.042 


\section{WEBSITES \& BLOGS}

Personal website

http://www.kubben.nl

Personal weblog

http://DigitalNeurosurgeon.com (= $\underline{\text { dign.eu }}$ )

Associate editor-in-chief and IT editor

http://surgicalneurologyint.com

Dutch Society for Neurosurgery

http://nvvn.org

Blog at Artsennet.nl

http://www.artsennet.nl/opinie/artsen-blogs/Pieter-Kubben.htm

Dutch Society for Neurosurgical Residents (until 2013)

http://nvna.info

Pilot project for online collaboration with mobile output (until 2008)

http://neurowiki.com 


\section{AWARDS, MEDIA \& VIDEO}

One of six "Need to Know Apps for Healthcare professionals in 2013" (Dec 2013)

Editor's pick award "Best Windows 8 Apps" (Dec 2013)

Listed as the \#1 app for neurosurgery in CNS Quarterly magazine (Fall 2013)

Website/app of the month. Neurosurgery's Brain School, University of Toronto (Sep 2013)

Radio interview for BNR on eHealth (Jun 2013, Dutch)

Magazine interview for Zorgvisie (Jun 2013, Dutch)

Magazine interview for VVAA / Arts \& Auto (May 2013, Dutch)

Newspaper interview for Financieel Dagblad (Mar 2013, Dutch)

Listed as a Top Ten "Best Top Free Medical Apps" (Mar 2013)

Listed as one of the "indispensable tech-tools for nurses" (Mar 2013)

Cover article on "Doctor App" in newspaper De Limburger (Jan 2013, Dutch)

Article in CNS Quarterly magazine - Winter 2013 (Jan 2013)

Named one of the "Top Ten Internet-Smart Doctors in the WORLD" (Dec 2012)

Honorable Mention in iPad Top Apps series on iMedicalApps.com (Jun 2012)

Article in the British Journal of Neurosurgery (Jun 2011)

Article in the IBTA's Brain Tumour, World Edition 2011

Presentation on TEDxMaastricht (Apr 2011; watch on YouTube)

Interview in Mozaiek, Atrium MC magazine (Apr 2011, Dutch)

Back cover on MediRisk magazine "Alert" (Mar 2011, Dutch)

News item on Neurosurgic.com (Mar 2011)

Article on iMedicalApps.com (Mar 2011) 
$\underline{\text { Interview in Medisch Contact magazine (Mar 2011, Dutch; see cover) }}$

Interview Dagblad De Limburger / Limburgs Dagblad (Mar 2011, Dutch)

Article in MacFan magazine (Feb 2011, Dutch); "neuroloog" is an error...

Article in Observant (2011, Dutch)

Press release Maastricht University Medical Center (2011)

Interview Nederlands Tijdschrift voor Geneeskunde (2011, Dutch)

Article on Reach Out Pro (2010)

Top 20 Free iPhone Medical Apps For Health Care Professionals (2010)

Article in Arts \& Auto, VVAA magazine (2010, Dutch)

Interview American Medical Association (2010)

33 iPhone Apps Every Healthcare Professional Needs (2010)

Free iPhone medical apps that every doctor can use (on KevinMD.com, 2010)

Top 10 Free iPhone Medical Apps for Health care Professionals (2010)

Interview Observant (2010, Dutch)

Interview iMedicalApps.com (by @OrthoOnc, 2010)

Television interview on $\underline{\mathrm{L} 1}$ about intraoperative MRI. 17 March 2010. (watch video on YouTube)

"Prijs voor medicus met ICT-genen". Automatiseringsgids. (2004, Dutch)

"Arts wint internationale prijs met 'elektronisch spiekbriefje'”. MedNet. (2004, Dutch)

"Prijs voor beslissingsondersteunende software voor medisch onderwijs". (2004, Dutch) 


\section{APPS}

NeuroMind

the world's \#1 ranked neurosurgical app and three times listed in the widely cited "Top Apps" on iMedicalApps.com. Available for iPhone, iPad, Android and Windows 8.

SLIC

an app for iPhone and iPad on subaxial cervical spine injury. It offers an evidence-based decision supporting system on surgical indications and technical approaches.

Safe Surgery

a dedicated iPhone implementation of the WHO Safe Surgery checklist. This digital version includes a progress indicator and feedback after each of the three check moments.

SNI Mobile

an app for iPhone, iPad and Android for the open access journal Surgical Neurology International.

OrthoRef

an app with more than 100 orthopedic scores and classification systems for clinical practice.

AIOS app

a project in collaboration with SoFoKleS, De Jonge Orde, LVAG and Modernisering Medische Vervolgopleidingen. 


\section{CONTACT}

Pieter Kubben can be contacted by various digital channels.

\section{E-mail}

pieter@kubben.nl

Twitter

http://twitter.com/DigNeurosurgeon

\section{Facebook}

http://www.facebook.com/pkubben

\section{Linkedln}

http://www.linkedin.com/pub/pieter-kubben/b/263/365 